



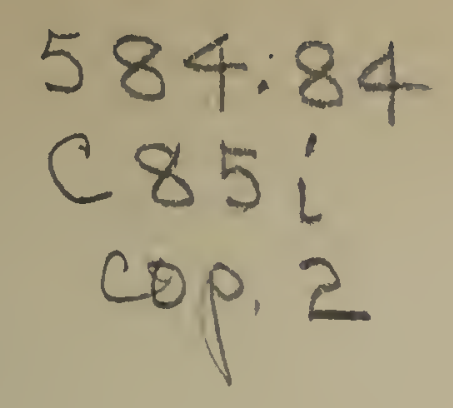

\section{The Iowa Sedges.}

BY R. I. CRATTY.

The Cyperacea or Sedye Family includes about one-twelfth of the flowering plants found within the limits of our state. It comprises about $6_{5}$ genera and 3,000 species of wide geographical distribution but most numerous in the north temperate zone. Of the 20 genera found in the northern United States and Canada, Io are known to occur in Iowa, and it is probable that two others, Cladium and Khynchospora, will yet be found.

The sedges have solid stems which are usually triangular, the sheaths of the leaves being closed. The flowers, which are arranged in spikes or spikelets, are in the axils of single scales, the perianth none, or replaced by bristles in Eriophorum, Dulichium, and in most species of Eleocharis and Scirpus. 'The fruit is a triangular or lenticular akene, which in the genus Carex is inclosed in a sac, technically called a perigynium.

There is found in "Jowa very nearly the same number of species belonging to each of the two great families, the $C y$ peracece and the Graminece, but in the number of individual plants the former is very greatly out-numbered by the latter. This disparity, so noticeable in our original flora, is being increased every year as the introduced and cultivated grasses are rapidly taking the place of the sedges on all tillable and closely pastured land.

Those species of sedge, belonging principally to the genus Carex, found on upland prairies and in the woods are of considerable economic value for pasturage, but on the open lands are usually so mature at the time the native grasses are ready to be mowed as to be of little value for hay. If closely pas-

$$
\mathrm{IV}-4 \quad 2 \quad \mathrm{D}
$$


tured the upland prairie sedges are quickly destroyed, but those found in the woods where the shaded ground retains moisture better, survive much longer.

When we consider the great number of species in the sedge family, and their wide geographical distribution, it is remarkable that an introduced foreign species is so rarely met, there being but a very few in the United States, and so far as known, not one within the limits of Iowa. Compared with the Graminece in this respect the difference is very striking. The troublesome introduced grasses of our state are, with one or two exceptions, annuals, and all well fitted by nature for the rapid dissemination of their seed into new localities by man's agency as he carries on his agricultural operations, even though he may do his best to prevent it. The carices which comprise much the greater part of the sedge flora of the land suitable for cultivation being perennials are ill fitted to survive where the soil must be frequently turned by the plow, but in Cyperus esculentus L. we have at least one exception, which on account of its numerous, small tubers is able to live in low cultivated land, and is troublesome in some localities.

In the distribution of our native plants into new localities by natural agencies the wind is a very important factor, but with the exception of a few species the distribution of the sedges by this means is comparatively slow. The fruit of such plants, however, as the species of Eriphorum, is quite well fitted for rapid distribution by high winds. The seeds of most of our Composite and many other plants which mature late in autumn, are often carried great distances over the crusted snow by the strong winter winds, but the fruit of the sedges, with very few exceptions, is not retained on the plants long enough to avail of this latter means of transportation. To the action of waves on our ponds and lakes, and to the currents of streams, especially during high water, we must attribute much credit for the distribution of the seeds of sedges. This is especially true of those carices having an inflated perigynium which are thus enabled to float very 
readily. An equal amount of credit is perhaps due to the birds, especially to the migratory water-fowl, which pass over the state in great numbers every spring and autumn. The small and very numerous seeds of the species of Cyperus, Eleocharis, and other shore-loving sedges fall soon after maturity, and mingling with the sand and mud on the shores of lakes and streams may very readily adhere to the feet and legs of these birds and be carried by them long distances in their migrations, while the akenes of many of the larger fruited sedges when eaten by the birds are undoubtedly protected by the indurated seed-coats which are characteristic of the plants of this family.

Those species of sedges which delight in very wet situations seldom flower or fruit except under normal conditions of moisture. The author has observed several species of Carex remaining unfruitful under unfavorable conditions for a period of from five to ten years.

The sedge flora of Iowa is characteristically eastern and corresponds quite closely with that of the bordering states, and though lying just east of the great plains, but one species, Carex stenophylla Wahl. has yet been found which does not occur east of the Mississippi River. The richest portion of the state in sedges is that bordering on this great water-way. This may be accounted for partly because of the greater diversity of soil, surface, woodland, and prairie in that region, and partly because the natural agencies for the distribution of seeds, and the greater rainfall combine to favor that portion of the state.

In the preparation of this paper over one thousand specimens, comprising several times that number of individual plants, have been examined, representing all portions of the state, especially the eastern-central, and northern portions which have been the most thoroughly explored. The region from Sioux City to the southwestern corner of the state is the poorest represented in the citations, and it is in this region that additional western species are to be the most confidently expected.

$$
\mathrm{IV}-4 \quad 2 \quad \mathrm{D}_{2}
$$


Of the species herein listed $\mathrm{I}_{5}$ are annuals, divided among the genera as follows: Cyperus, 7; Eleocharis, 4; Stenophyllus, I ; Fimbristylis, I; Scirpus, I; and Hemicarpha, I, The remaining species of these and all the other genera are perennials.

The classification followed is that of Britton and Brown's Illustrated Flora ( $1896-7$ ). The names used in Gray's Mamual, 6th edition, and in previously published lists, when different, are given in the synonymy. In this order, however, the changes made are comparatively few.

In the study of the material at $\mathrm{my}$ command $\mathrm{I}$ have been greatly aided by having access to several sets of plants determined by Prof. L. H. Bailey, of Cornell University, Ithaca, New York, and by Dr. N. L. Britton, of Columbia University, New York City. The former gentleman has at various times greatly aided me by the determination of carices and by the exchange of specimens.

My thanks are also here tendered to the following persons for specimens and other assistance: Prof. B. Shimek, of the Iowa State University for collections made in various parts of the state; Prof. Bruce Fink, of Upper Iowa University, at Fayette, for a set of the sedges of that region; Prof. L. H. Pammel, of the Iowa Agricultural College, for the privilege of studying the Cyperacea in the herbarium of that institution, for extensive collections made in various parts of the state, and for the loan of literature; Messrs. Wm. D. Barnes, of Blue Grass, and A. A. Miller, of Eldridge, Scott County, two most excellent collectors, for sedges from that region and for many valuable notes regarding soil, distribution, etc.; Prof. T. J. Fitzpatrick, of Graceland College, Lamoni, for specimens from Decatur County and from other localities; Prof. H. W. Norris and Frank W. Johnson, of Iowa College, Grinnell, for the loan of their private collections and a portion of the college herbarium; Dr. J. C. Arthur, of Purdue University, Lafayette, Indiana, for data and the loan of specimens; Prof. T. H. Baldwin, of Tabor, Iowa, for specimens of his own collection and a list of the sedges, with the accompany- 
ing data, in the Arthur collection exhibited at the Centennial Exposition, and now the property of Tabor College. My thanks are also due to numerous collectors whose names appear in the citations. For numerous kind favors $\mathrm{I}$ am also indebted to Prof. T. H. Macbride, of the Iowa State University, at whose request this paper is prepared.

It is felt that this catalogue is necessarily incomplete, there being so large an area of the state which has not yet been thoroughly explored. The acknowledged difficulty of this group of plants has caused them to be neglected more than the higher Phanerogams, but the rapid conversion of nearly the whole area of the state into pastures or cultivated fields should incite those interested in our indigenous flora to secure specimens for preservation with as little delay as possible. Mature fruiting specimens of this group of plants from new localities or of species not herein listed are solicted by the author that they may be studied and published in future lists, full credit for which will be given.

The table here appended gives the extent in genera and the number of species and varieties of sedges listed in the following local and state catalogues:

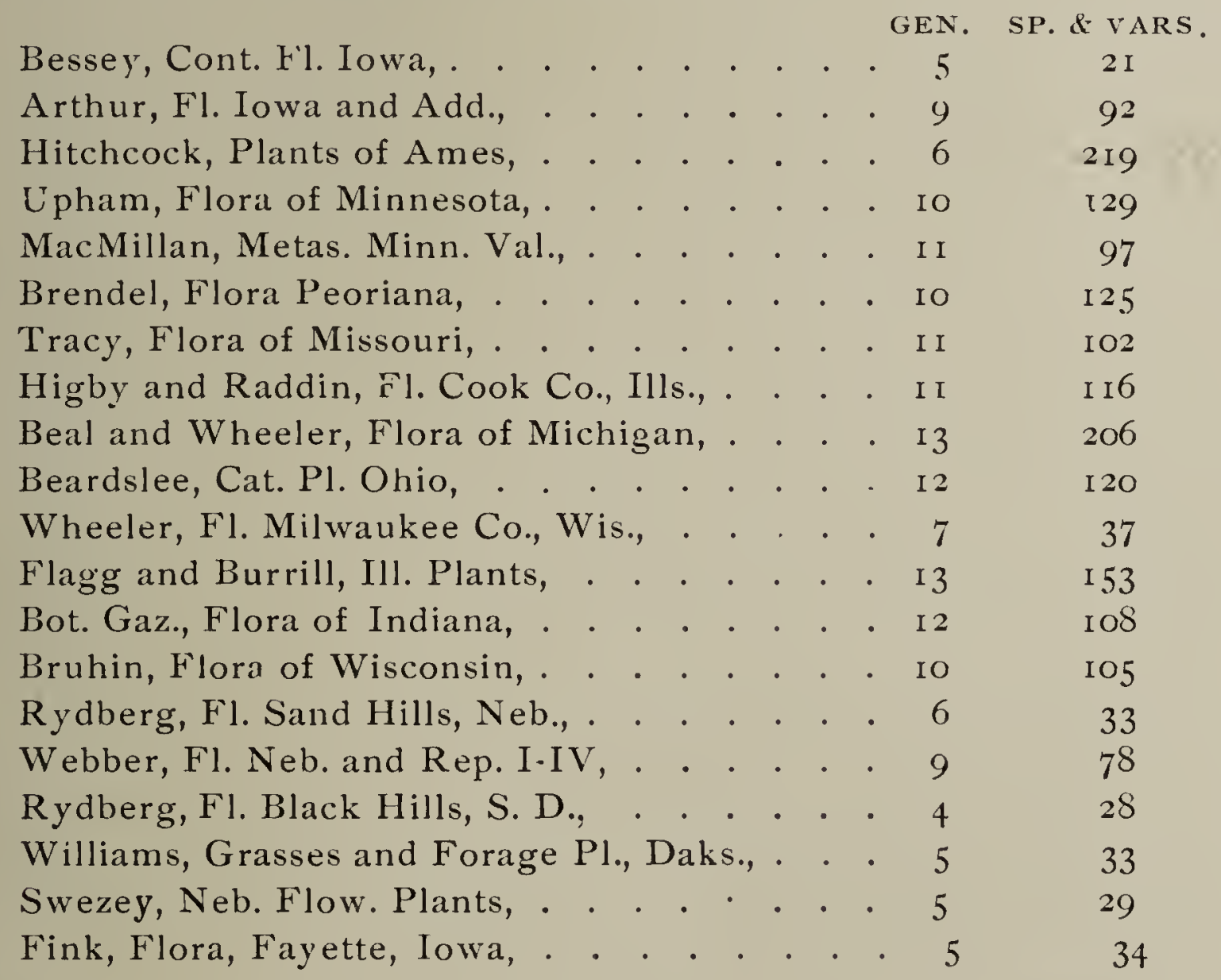


Cyperus L. Sp. Pl., 44 (I753).

A very large genus of annual and perennial sedges, widely distributed in tropical and temperate regions. The species are of little economic value, furnishing a small percentage of inferior pasturage along the margins of ponds and streams and on marshy land.

Species about 650 .

Illustrated Flora, 32 ; Gray's Manual, 6th ed., 25; MacMillan, Metas. Minn. Valley, 9; Arthur, Flora of Iowa, 8; Tracy, Flora of Missouri, I6; Brendel, Flora Peoriana, 9; Webber, Flora of Nebraska, and Rep. I-Iv, II; Williams, Grasses and Forage Plants of the Dakotas, 4; Fink, Flora of Fayette, Iowa, 6.

I. C. diandrus Torr. Cat. N. Y., 9o (ISI9).

Illus. Flora, I. 236, fig. 544; Gray's Man, 6th ed., 569; Hitchcock, Pl. Ames 523; MacMillan, Metas. Minn. Val., 93; Tracy, Fl. Missouri, 90; Brendel, Fl. Peoriana, 6I; Wheeler, Fl. Milwaukee Co., Wis., I86; Rydberg, Fl. Sand Hils, Neb., I84; Fink, Iowa Acad. Sci., Iv, ro5.

Low ground, sandy shores of streams and lakes. Probably throughout the state but not common. Quite variable, closely approaching the next species in some forms.

Muscatine and Ames, Hitchcock; Decorah, I88I, Holway; Fremont County, I894, Fink; Clinton County, is96, Pammel; Moscow, 1894, Barnes \& Miller; Grinnell, Aug., I886, Fohnson.

2. C. rivularis Kunth. Enum., il, 6 (I 837 ).

C. diandrus var. castaneus Torr., Ann. Lyc. N. Y., III, 252 (I836), not Willd. (1798).

Illus. Flora, I, 236, Fig. 545; Gray's Man., 6th ed., 569; Arthur, Fl. Iowa, 33; Hitchcock. Pl. Ames, 523; MacMillan, Metas. Minn. Val., 93; Webber, App. Fl. Neb., 24; Fink, Iowa Acad. Sci. 1v, 105.

Same situations as the last. Varies from a couple of inches to over a foot in height. A beautiful species, the bright, chestnut-colored scales very conspicuous.

Ames, I875, Arthur; Lawler, I89o, Rolfs; Emmet and Dickinson counties, various collections, Cratty; Woodbine, I874, Burgess; Scott and Muscatine counties, frequent, Barnes \& Miller; Charles City, Aug., I875, Arthur. 
3. C. inflexus Muhl. Gram., i6 (I8I7).

C. aristatus Boeckl. Linniea, $\mathrm{xxxv}, 500$ in part (1868), not Rottb., Desc. \& Icon., 23 (1773).

Illus. Flora, I, 273, fig. 549; Gray's Man., 6th ed., 507; Arthur, Cont. Fl. Iowa, II; Hitchcock, Pl. Ames, 523: MacMillan, Metas. Minn. Val., 93: Tracy, Fl. Missouri, 91; Brendel. Fl. Peoriana, 61; Hale, Add. Fl. Wis., 5; Rydberg, Fl. Sand Hills, Neb., 184 ; Rydberg, Fl. Black Hills, S. D., 526; Fink, Iowa Acad. Sci., Iv, 105.

Sandy margins of streams and ponds; throughout. The long, tapering, recurved points of the scales readily distinguish this from any of our other species.

Story county, I886, and Iowa City, I887, Hitchcock; Emmet county, I884, and Dickinson county, I896, C'ratty; Hamilton county, I89 , Rolfs; Fayette county, I894, Fink; Clinton county, I 896, Pummel; Johnson county, I894, Fitzpatrick; Nora Springs, July, I889, and Clear Lake, I889, Fohnson; Scott and Muscatine counties, Barnes \& Miller; Ames, Sept., I897, No. 444, C. C. Ball.

4. C. schweinitzil Torr. Ann. Lyc. N. Y., III, 276 (i836). Illus. Flora, I, 238, fig. 551; Gray's Man., 6th ed., 597: Arthur, Fl. Iowa, 33; Hitchcock, Pl. Ames, 523; MacMillan, Metas. Minn. Val., 92: 'Tracy, Fl. Missouri, 9I ; Brendel, Fl. Peoriana, 88; Bruhin, Fl. Wis., 278; Rydberg, Fl. Sand Ililis, Neb., 183 ; Williams, Grass and Forage Pl. Daks., 41; Fink, Iowa Acad. Sci., 1v, 105.

Sandy margins of streams and lakes; quite variable. Common, at least through the northern half of the state.

Charles City, July, I872, Arthur; Marshalltown, I891, Stczuart; Ames, I889, Hitchcock; Newton, I891, Drezr; Cedar Rapids, 189 I, Pammel; Emmet county, 1882, and Spirit Lake, I896, Cratty'; Fremont county, I888, Hitchcock; Fayette county, I894, Fink; Johnson county, Fitzpatrick; Lynville, Jasper county, July, I888, Norris; Scott and Muscatine counties, Barnes \& Miller.

\section{C. acuminatus Torr. \& Hook. in Torr. Cyp. 435 (1836).}

Illus. Flora, I, 239, fig. 553; Gray's Man., 6th ed., 570; Arthur, Cont. Fl. Iowa, Iv; Tracy, Fl. Mo., 90; Brendel, Fl. Peoriana, 6r; Bruhin, Zwei. Nach. Fl. Wis., 643; Webber, App. Fl. Neb., 24; Rydberg. Fl. Black Hills, S. D., 526. 
Margins of streams; well distributed throughout the state, but not common.

Woodbury county and Sioux City, i 888, Hitchcock; Oquawka, Ills., Patterson; Banks of Wapsipinicon, Scott county, July, I896, and Folletts, Clinton county, Barnes \& Miller; Plymouth county. Arthur, l. c.; Montrose, I883, Ehinger; Jefferson county, I.897, No. 455, Baldwin.

6. C. esculentus $L$. Sp. Pl., 45 (I753). Pl。x.

Illus. Flora, I, 24I, fig. 559; Gray's Man., 6th ed., 57r; Arthur, FI. Iowa,

33; Hitchcock, Pl. Ames, 523; MacMillan, Metas. Minn. Val., 92;

Tracy, Fl. Mo., 9ı; Brendel, Fl. Peoriana, 6ı; Hale, Add. Fl. Wis., 5; Webber, Fl. Neb., 99; Fink, Iowa Acad. Sci., Iv, I05.

Central, eastern and southern portions of the state. The narrow, many flowered spikelets are straw-colored when mature, the leaves a lighter green than those of $C$. strigosus or C.specsiosus. Propagated by its small, edible tubers which make it occasionally troublesome in low, cultivated fields.

Charles City, July, 1875, Arthur; Iowa City and Ames, I889, Hitchcock; Marshalltown, I89I, Stezuart; Fayette county, i893, Fink; Clinton county, i896, Pammel; Clayton county, June, I895, Fitzpatrick; Scott and Muscatine counties, where it is rather frequent in cultivated fields, Barnes \& Miller; Peru, June 20, I897, No. 452, Hollingsworth; Libertyville, I 897, Baldwin; Mt. Pleasant, Oct. I, I 897, Dr. Mitte.

7. C. erythrorhizos Muhl. Gram., 20 (I8I7). Pl. I.

Illus. Flora, I. 241, fig. 560; Gray's Man., 6th ed., 57I; Hitchcock, Pl. Anes, 523; MacMillan, Metas. Minn. Val., 92; Tracy, Fl. Mo., 9r; Brendel, Fl. Peoriana, 6r; Bruhin, Fl. Wis., 278 ; Williams, Grass. and For. Pl. Dakotas, 4I.

Probably throughout the state; banks of streams and margins of lakes. Not before reported from Iowa. The linear spikelets of many very small flowers with their bright, chestnut-colored scales are very pretty objects under the lens.

Estherville, bank of Des Moines River, I881, Cratty; Story county and Iowa City, Hitchcock; Clinton county, i896, Pammel; Scott and Muscatine counties, Barnes \& Miller; Iowa Lake, I897, Pammel \& Cratty. 
8. C. specrosus Vahl. Enum., II, 364 (1806).

C. michauxianus Gray, Man., 5th ed., 554 (1867), not of Schultes (1824).

Illus. Flora, I, 242, fig. 562; Gray's Man., 6th ed., 572; Arthur, Fl. Iowa, 33; MacMillan, Metas. Minn. Val., 91; Tracy, Fl. Mo., 91; Bessey, Cont. Fl. Iowa, I23; Brendel, Fl. Peoriana, 6r; Hale, Add. Fl. Wis., 5: Webber, Fl. Neb., 99; Williams, Grass. and For. Pl. Dakotas, $4^{\text {r. }}$

Low grounds, marshes and margins of streams and ponds. Throughout the state; variable. In marshes often 2 feet high; not as handsome in the dried specimen as many other species of the genus. Within our limits it is often found associated with $C$. erythrorhizos.

Iowa City, Hitchcock; Woodbine, I874, Burgess; Davenport, I889, Hitchcock; Grinnell, I886, Johnson, Scott and Muscatine counties, 1896, Barnes \& Miller; South shore of Iowa Lake, Emmet county, Aug. 27, I897. Cratty; Clinton county, I896, Pammel; Decatur county, I897, Fitzpatrick; Crestun, Sept. 13, 1897, No. 464, E. P. Bettenga; Libertyville, I897, Baldzin.

Note.-C. engelmanni Steud., Syn. Pl. Cyp. 47 (I8.53), has been reported from Iowa, but 1 have been unable to find any specimen of this species in any collection in the state. It is reported by Wheeler in Fl. Milwaukee Co., Wis., I86; by Tracy in Fl. Mo., 90; by Brendel in Fl Peoriana, S8, and by Webber in Fl. Neb., 95. It probably occirs in the southern part of the state, and can be distinguished from the above, to which it is closely related, by its more slender spikelets, and the tips of the scales not reaching to the succeeding one on the same side.

9. 'C. strigosus $L$. Sp. Pl., I, 47 (I.753)'.

Illus. Flora. I, 243, fig. 565; Gray's Man. 6th ed., 57 I Arthur, Fl. Iowa, 33; Hitchcock, Pl. Ames, 523; MacMillan, Metas. Minn. Val., 91; Tracy, Fl. Mo., 91; Brendel, Fl. Peoriana, 6r; Wheeler, Fl. Milwaukee Co., Wis., I86; Rydberg, Fl. Sand Hills, Neb., I83; Fink, Iowa Acad. Sci., IV, 105.

Our commonest and most variable species in low, wet ground, growing from a few inches to two or three feet in height. Perennial by basal corm-like tubers.

Grinnell, Aug., I884, Norris, Fohnson; Iowa City, Hitchcock; Cedar Rapids, I89I, Pammel; Muscatine, Reppert; Emmet county, I896, and Kossuth county, I897, Cratty; Decatur county, Sept., I896, Fitzpatrick; Scott and Muscatine 
counties, I896, Barnes \& Miller; Charles City, Aug., I875, Arthur; Muscatine, 1897, Ball.

The following varieties also occur, in Iowa, specimens of each, determined by Dr. N. L. Britton being in the herbarium of the Iowa Agricultural College at Ames.

io. C. strigosus robustior Kunth. Enum., ir, 88 (i837). Illus. Flora, I, 243 .

Habit and range of the type, but less common. Spikelets nearly an inch long, 10-25 flowered.

Ames and Iowa City, Hilchcock; Woodbine, I87S, Burgess. II. C. strigosus capitatus Boeckl. Linnæa, xxxvi, 347 ( $1869-70)$.

Illut. Flora, I, 243.

Low ground in marshes, rare; not before reported from the state. A very small, slender form, the plants only a few inches tall with the 5-I5 flowered spikelets arranged in capitate clusters. It is possible that this is merely a state of the type produced by a very dry season.

Algona, Hitchcock; Emmet county, in a marsh $1 / 2$ miles east of Armstrong, Aug., I896, Cratty.

i2. C. Strigosus compositus Britton. Bull. Torr. Club, XIII, 2 I 2 ( I 886).

Illus. Flora, I, 243.

Rather rare in swamps or low ground. The umbel very compound, the 4-6 flowered spikelets clustered in cylindrical heads. Plants 6-1 8 inches high.

Charles City, Arthur; Lawler, I89o, Rolfs; Scott county, Barnes \& Miller; Iowa Lake, Emmet county, Aug., I897, Cratty.

I3. C. Filiculmis Vahl. Enum., II, 328 (i806).

Illus. Flora, I, 245, fig. 57I; Gray's Man., 6th ed., 570; Arthur, F1. Iowa, 33;

Hitchcock, Pl. Ames, 523; MacMillan, Metas. Minn. Val., 92; Tracy,

Fl. Mo., 9r; Brendel, Fl. Peoriana, 6r; Bruhin, Fl. Wis., 278; Webber,

Fl. Neb., 99; Fink, Iowa Acad. Sci., rv, ro5.

Sandy soil, margins of streams and lakes; most frequent in the eastern half of the state. Quite variable. 
Ames, I889, Hitchcock; Charles City, I875, Arthur; Cedar Rapids, I89I, Pammel; Iowa City, Hitchock; La Cirosse, Wis., Pammel; Fayette county, I894, Fink; Clinton, I895, Pammel; Cedar Rapids, a peculiar form in general appearance approaching C. schweinitzii Torr., Hitchcock; Scott and Muscatine counties Barnes \& Miller; Hancock county, I88 I, Ehinger; Johnson county, July I 5, I897, Shimek; Muscatine Island, Louisa county, Aug. I, I897, Meyers; Belmond, I897, Pammel.

D U L I C H I U M L. C. Richards. Pers. Syn., I, 65 (I805).

A monotypic genus of the eastern half of North America.

I. D. Arundinaceum (L.) Britton. Bull. Torr. Club, xxi, 29 ( I 894).

D. spathaceum, Pers., Syn., I, 65 (I805).

Illus. Flora, I, 247, fig. 576; Gray's Man ., 6th ed., 573; Arthur, Fl. Iowa, 33; MacMillan, Metas. Minn. Val., 90; Tracy, Fl. Mo., 91; Brendel, Fl. Peoriana, 61; Wheeler, Fl. Milwaukee Co., Wis., I86; Webber, App, Fl. Neb., 24 .

Low, wet places; central and eastern portions of the state; rather rare.

Ames. June, I87I, Arthur; Story county, Hitchcock; La Crosse, Wis., Pammel. In bogs along Skunk River, Jasper county, July 3, I886, Fohnson; Moscow, Muscatine county, I893, and Noels, Scott county, I894, Barnes \& Miller.

E L E OC'H A R IS R. Br. Proc. Nov. Hol., I, 209 (I8Io).

Sedges with simple, leafless culms, bearing single capitate or elongated spikes, the akene surmounted by a tubercle and usually subtended with bristles. Annuals or perennials, abounding in water or wet situations.

Species about Ioo.

Illus. Flora, 22; Gray's Man., 6th ed., 21; MacMillan, Metas. Minn. Val., 7 . Arthur, Fl. Iowa, 5; Tracy, Fl. Mo., 6; Brendel, Fl. Peoriana, 5; Webber, Fl. Neb. and Rep. I-Iv, 6; Fink, Fl., Fayette, Iowa, 3 . 
I. E. atropurpurea (Retz.) Kunth. Enum. II, I5 I (1837). Illus. Flora, I, 250, fig. 582; Webber, App. Fl. Neb., 24; Dr. Britton in Torr. Bull. xviri, 166 .

A widely distributed species of the southern United States and tropical America.

Found growing in wet sand at Fruitland, Muscatine county, by Mr. Reppert. The plant is about $2 \frac{1}{2}$ inches high, the culms wiry, the spikes ovoid, $\mathrm{I} / 2$ lines long by $\mathrm{I}$ line wide. It resembles the eastern $E$. olivacea Torr. but grows from an annual root. Probably very rare within our limits; not before reported from Iowa. Mr. Wm. D. Barnes who communicated the plant to me cites this as a probable example of a southern plant brought to us by the agency of migratory water-fowl which resort to that locality in great numbers.

2. E. ovata (Roth.) R. \&S. Syst., II, I52 (I8I7).

E. obtusa Schultes, Mont., II, 89 (I824).

Illus. Flora, I, 25I, fig. 584; Gray's Man., 6th ed., 574; Arthur, Cont. Fl. Iowa, Iv; MacMillan, Metas. Minn. Val., I02; Tracy, Fl. Mo., 9I; Brendel, Fl. Peoriana, 6r; Bruhin, Fl. Wis., 278; Webber, Fl. Neb., 99; Fink, Iowa Acad. Sci., Iv, I05.

Wet soil, southern and eastern portions of the state. Very variable in regard to height, and size of the spikes.

Ames and Iowa City, Hitchcock; Kellogg, I 877, collector unknown; Keokuk, Hitchcock; Fayette county, 1894, Fink; Moscow, I894, Barnes \& Miller; Appanoose county, July, 1896, and Decatur county, Aug., I898, Fitzpatrick; Grinnell, June, I894, Fohnson; Peru, July 20, I897, No. 393, Hollingsworth; Birmingham, Aug. I5, I897, Baldwin.

Note.-E. engelmanni Steud., Syn. Pl. Cyp., 79 (1855), (E. obtusa var. detonsa Gray) has been collected on the Mississippi bottoms at Oquawka, Ill., by Mr. H. N. Patterson, and probably occurs in the southeastern part of the state. It is also reported from Kansas by Smythe.

3. E. palustris (L.) R. \& S. Syst., II, I5I (I8I7).

Scirpus palustris L. Sp. Pl. 47 (1753).

Illus. Flora, I, 25I, fig. 586; Gray's Man., 6th ed., 575; $\Lambda$ rthur, Fl. Iowa, 33;

Hitchcock, Pl. Ames, 523; MacMillan, Metas. Minn. Val., IoI; Tracy, Fl. Mo., 9r; Bessey, Cont. Fl. Iowa, I23; Brendel, Fl. Peoriana, 6r; Wheeler, Fl. Milwaukee Co., Wis., I86; Webber, Fl. Neb., 99; Rydberg, Fl. Black Hills, S. D., 527; Fink, Iowa Acad. Sci., Iv, I05. 
Everywhere very common in low ground, margins of streams and ponds, and in swamps. Very variable in size, from I foot or less in height, with spikes $2-6$ lines in length, to 4 feet high, with spikes 8 lines long and 3 lines wide.

Ames, various collectors; Emmet county, Cratty; Hamilton county, I891, Rolfs; Fayette county, 1894, Fink; Shelby county, Fitzpatrick; Grinnell, June, I886, Fohnson; Scott and Muscatine counties, Barnes \& Miller; Decatur county, I897, Fitzpatrick; Missouri Valley, June 21, I897, Pammel; Gilbert, July I7, I897, Combs \& Ball.

4. E. Palustris glaucescens (Willd.) Gray. Man., 5th ed., $55^{8}$ ( 1867 ).

Illus. Flora, I, 252; Gray's Man., 6th ed., 575; Upham, Fl. Minn., I 51; Rydberg, Fl. Sand Hills, Neb., I84.

Low, wet ground, eastern half of the state; perhaps often confounded with the type from which it is distinguished by its more slender culms, smaller akene, and narrower and more acute tubercle. Not before reported from Iowa.

Davenport, I889, and Iowa City, Hitchcock.

5. E. acicularis (L.) R. \& $S$.

Scirpus acicuiaris L. Sp. Pl., I, 48 (1753).

Illus. Flora, I, 252, fig. 587 ; Gray's Man., 6th ed., 576; Arthur, Fl. Iowa, 33;

Hitchcock, Pl. Ames, 523; MacMillan, Metas. Minn. Val., Ioo; Tracy;

Fl. Mo., 91; Bessey, Cont. Fl. Iowa, I23; Brendel, Fl. Peoriana, 62;

Bruhin, Fl. Wis., 278; Rydberg, Fl. Sand Hills, Neb., I $8_{4}$; Williams,

Grass. and For. Pl. Daks., 4I ; Fink, Iowa Acad. Sci., IV, IO5.

Very common throughout; edges of streams and ponds and low wet meadows; spikes more loosely flowered than our other species.

Charles City, Aug., 1875, Arthur; Iowa City, Hitchcock; Emmet and Dickinson counties, I896, Cratty; Fayette county, I893, Fink; Ames, I883, Hitchcock; Powesheik county, July, I888, Fohnson; Scott and Muscatine counties, Barnes \& Miller; Kossuth county, I897, Cratty; Missouri bottom near Bartlett, Sept. 20, 1897, Baldzvin; Gilbert, July I 7, I887, No. 438, Combs \& Ball. 
6. E. Wolfir (A. Gray) Britton. Jour. N. Y. Micros. Soc. $\mathrm{v}, \operatorname{IO5}(\mathrm{r} 889$.

Scirpus wolfii Gray. Proc. Am. Acad., x, 77 (1874).

Illus. Flora, 1. 252, fig, 588; Gray's Man., 6th ed., 576; Arthur, Cont. Fl. Iowa, vi; MacMillan, Metas. Minn. Val., 99; Brendel, Fl. Peoriana, 6I.

Low ground on prairies, the culms much compressed, light colored and weak. A rare species, also occurring locally in Illinois and southern Minnesota.

Emmet county, I886, Cratty; Iowa City, Hitchcock.

\section{E. tenuis (Willd.) Schultes.}

Scirpus tenuis Willd, Enum., I, 76 ( I 809).

Illus. Flora, I, 255, fig. 595; Gray's Man., 6th ed., 575; MacMillan, Metas.

Minn. Val., Ioo; Tracy, Fl. Mo., 91; Brendel, Fl. Peoriana, 62; Wheelèr, Fl. Milwaukee Co., Wis., I86.

Probably rare within our limits; not before reported from Iowa. Its perennial habit at once distinguishes the growing plant from E. intermedia (Muhl.) Schultes, with which the dried plant is apt to be confounded when not in mature fruit.

Iowa City, Hitchcock; Grinnell, May, I886, Norris; Decatur county, May 24, I897, probably this, the fruil not matured, Fitzpatrick.

8. E. acuminata (Muhl.) Nees. Linnæa, ix, 294 ( ( 835 ).

E. compressa Sulliv. Sill. Jour., XLII, 50 (I $\left.8_{42}\right)$.

Illus. Flora, I, 255, fig. 595; Gray's Man., 6th ed., 576; Arthur, Fl. Iowa, 33;

MacMillan, Metas. Minn. Val., IoI; Tracy, Fl. Mo., 91; Brendel, Fl.

Peoriana, 6I; Wheeler, Fl. Milwaukee Co., Wis., I86; Rydberg, Fl. Bl. Hills, S. D., 527 .

Low ground, southern and eastern portions of the state. Probably not very common within our limits.

Iowa City, Hitchcock; Grinnell, June, 1894, Fohnson; Scott and Muscatine counties, Barnes \& Miller; Hancock county, I88r, Ehinger; Ames, July, I875, Arthur; Peru, July, I897, No. 395, Hollingsworth.

9. E. intermedia (Muhl.) Schultes. Mant., iI, 9i (I824).

Illus. Flora, I, 255, fig. 597; Gray's Man., 6th ed., 575; Arthur, Fl. Iowa, 33; MacMillan, Metas. Minn. Val., ıoo; Tracy, Fl. Mo., 91; Brendel, Fl. Peoriana, 61; Bruhin, Fl. Wis., 278. 
Low ground, probably rare within our limits. Distinguished from E. tenuis (Willd.) Schultes, which it somewhat resembles, by its annual, fibrous root, smoother akene with persistent bristles.

Story City, I891, Pammel; Charles City, Aug., I875, Arthur.

\section{STE N O P H Y L US Raf. Neog. 4 (I825).}

A genus of about 20 annual or perennial sedges, represented in the northern United States by a single species.

I. S. capillaris (L.) Britton. Bull. Torr. Club, xxi, 3o ( I894).

Fimbristylis capillaris A. Gray. Man., Ist ed., $530\left(\mathrm{IS}_{4} 8\right)$.

lllus. Flora, I, 258, fig. 603; Gray's Man., 6th ed., 578; Arthur, Cont. Fl. Iowa Iv; MacMillan, Metas. Minn. Val., I03; Tracy, Fl. Mo., 92 ; Brendel, Fl. Peoriana, 8s; Hale, Add.Fl. Wis., 5; Webber, A pp. Fl. Neb., 24.

Rare in sand on banks of streams; eastern portion of the state. Readily distinguished from the next growing in similar situations by its very numerous and finely capillary culms.

Fruitland, Muscatine county, Aug., I896, and Noels, Scott county, Barnes \& Miller; bank of Mississippi River at Oquawka, Ills., Patterson.

\section{F I M B R I S T Y L IS Vahl. Enum., II, 285 (I806).}

A large genus with culms leafy below and bearing spikelets in small umbels or capitate heads. It differs from the preceding genus in having the swollen base of the style deciduous.

North America, $\triangle$ or 9 species.

Illus. Flora, 4; Gray's Man., 6th ed., 3; Tracy, F!. Mo., 2; Webber, App. Fl. Neb., I.

I. F. autumnalis (L.) R. \& S. Syst., II, 97 (I8I7).

Scirpus autumnalis L. Mont., II, ISo ( $178 \mathrm{I})$.

Illus. Flora, I, 26o, fig. 6o8; Gray's Man. 578; Tracy, Fl. Mo., 92 ; Brendel, Fl. Peoriana, 62. 
$\mathrm{R}$ are in the eastern part of the state, sandy margins of streams and ponds; variable.

Keokuk, Ehinger; Oquawka, Ills., Patterson; Fruitland, Muscatine county, a form more slender than the type in wet soil. Also from Moscow, a lower, very densely tufted form with minutely papillose-hairy leaves, the spikelets oblong, about 3 lines long, the akene larger. Barnes \& Miller.

Note.-F. castanea (Michx.) Vahl, Enum., II, 292 (I806), (F. spadicea var. castanea Torr.) was collected on the Mississippi bottoms near Oquawka, Ill., Aug., I $88_{4}$, by Mr. H. N. Patterson, and probably occurs on the Iowa side of the river. It is also reported from Nebraska and Missouri.

\section{SCIR PUS L. Sp. Pl., 47 ( I753).}

A large genus of annual or perennial sedges, our species varying in height from a few inches to eight or ten feet. Stems leafy in all the Iowa species except S. lacustris L. where they are reduced to basal sheaths.

Species about 200; 35 or 40 in the United States.

Illus. Flora, 28; Gray's Man., 6th ed., 17; Arthur, Fl. Iowa, 6; MacMillan, Metas. Minn. Val., 5; Tracy, Fl. Mn., 9; Brendel, Fl. Peoriana, 3; Webber, Fl. Neb., and Rep. I-Iv, 9; Williams, Grass and For. Pl. Daks., 5; Fink, Fl. Fayette, Iowa, 2.

I. S. hallit A. Gray. Man., 2nd ed., Add. (1863.)

S. supinus var. hallii A. Gray. Man., 5th ed., 563 (1867).

Illus. Flora, I, 264, fig. 6r 5; Gray's Man., 6th ed, 580; Tracy, Fl. Mo., 92;

Brendel, Fl. Peoriana, 88.

A low, tufted annual, growing in wet soil, and very rare within our limits. Not before reported from Iowa.

Muscatine county, Reppert. I am indebted to Mr. Wm. D. Barnes of Blue Grass for his single specimen for examination.

2. S. americanus Pers. Syn., I, 68 (i805).

S. triangularis (Pers.), MacMillan, Metas. Minn. Val., 99 (I892).

S. pungens Vahl. Enum., II, 255 (1806).

Illus. Flora, I, 255, fig. 6I8; Gray's Ma11., 6th ed., 579; Arthur, Cont. Fl.

Iowa, vi; Hitchcock, Pl..Ames, 523; MacMillan, Metas. Minn. Val., 99;

Tracy, Fl. Mo., 92; Brendel Fl. Peoriana, 62; Bruhin, Fl. Wis., 278;

Webber, Fl. Neb., 99; Rydberg, Fl. Bl. Hills, S. I)., 526. 
Rather rare in swamps and along the edges of ponds. Probably throughout the state.

Ames, 1885 , and Davenport, 1889, Hitchcock; Walled Lake, r889, Bessey; Powesheik county, June, I885, Fohnson; Scott and Muscatine counties, Barnes \& Miller; Granite, Lyon county, June, I897, Shimek.

3. S. lacustris $L$. Sp. Pl., I, 48 (1753).

S. validus Vahl. Enum., II, 268 ( ISO6).

Illus. Flora, I, 266, fig. 623; Gray's Man., 6th ed., 58o; Arthur, Fl. Iowa. 33;

Hitchcock, Pl. Ames, 523; MacMillan, Metas. Minn. Val.. 98; Tracy, Fl. Mo., 92 ; Bessey, Cont. Fl. Iowa, I23; Brendel, Fl. Peoriana, 62;

Wheeler, Fl. Milwaukee Co., Wis., I86; Rydberg, Fl. Sand Hills, Neb., I84; Rydberg, Fl. Bl. Hills, S. U., 526; Fink, Iowa Acad. Sci., Iv, Io5.

Our most common species; shallow water, margins of streams and lakes. Varies greatly in the size of its spikes and panicle, the culm from $1 / 4$ to $\mathrm{I}$ inch in diameter at the base. The leaves of this species are reduced to basal sheaths.

Ames, 1884, Hitchcock; Emmet county, 189o, and Spirit Lake, 1896, Cratty; Monticello, 1876, Bessey; Lawler, 1876, Rolfs; Charles City, Arthur; Greene, I891, Miss Price; Fayette county, 1894, Fink; Powesheik county, June, I895, Fohnson; Allamakee county, 1897, Pammel; Scott and Muscatine counties, Barnes \& Miller; Kossuth county, July 21, ı897, Pammel.

4. S. Fluviatilis (Torr.) Gray, Man, ist ed., 527 (1848).

S. maritimus var. fluviatilis Torr., Ann. Lyc. Iv, N. Y., III, 324 (1836).

Illus. Flora, I, 268, fig. 62S; Gray's Man., 6th ed., 58I; Arthur, Cont. Fl. Iowa, rr; Hitchisik, Pl. A nะ;, 5:3; MacMillan. Metas. Minn. Val., 98; Tracy, Fl. Mo., 92 ; Brendel, Fl. Peorıana, 88; Bruhin, Fl. Wis., 278 ; Rydberg, Fl. Sand Hills, Neb., IS 4 ; Williams, Grass. and For. Pl. Daks., 42 .

Marshes, central, and northern portions of the state, less common than the preceding. A very coarse plant with numerous leaves, one-half inch or more in width, and large, triangular black akenes, 2 lines long.

Ames, 1885, and Carnsforth, Hitchcock; Emmet and Kossuth counties, Cratty; Ames, 1877, Arthur; Jasper county, I886, Fohnson. 


\section{S. atrovirens Mull. Gram., 43, (I8I7).}

Illus. Flora, I, 269, fig. 630; Gray's Man., 6th ed., 581 ; Artbur; Fl. Iowa, 33; Hitchcock, Pl. Ames, 523;Mac Millan, Metas. Minn. Val., 97; Tracy, Fl. Mo., 92; Bessey, Cont. Fl. Iowa, I23; Fink, Iowa Acad. Sci., IV, ro5: Brendel, Fl. Peoriana, 62; Wheeler, Fl. Milwaukee Co., Wis., I86; Webber, Fl. Neb., 99.

Throughout the state; very common in low ground or swamps. A broad-leaved species with very numerous small spikelets in dense capitate clusters. The var. pallidus Britton has been found in Minnesota and Nebraska and is to be sought in the northwestern part of the state.

Woodbine, 1874, Burgess; Ames, I886, Hitchcock; Muscatine, Reppert; Fayette county, I894, Fink; Shelby county, June, I894, Fitzpatrick; Webster county, I89I, Hitchcock; Grinnell, July, 1895, Fohnson; Emmet and Kossuth counties, I897, Cratty; Scott and Muscatine counties, Barnes \& Miller; Charles City, Arthur; Boone, July, I897, Steele; Birmingham, Aug., I897, No. 453, Baldzin; Kossuth county, Aug. 21, I897, Pammel; Nevada, July 2, I897, Vernon; Mount Pleasant, Oct. I, I897, Dr. Mitte.

\section{S. lineatus Mich. Fl. Bor. Am., I, 32 (I8o3).}

Eriophorum lineatum Benth. \& Hook., Gen. Pl., i I I, I,052 (I883).

Illus. Flora, I, 270, fig. 635; Gray's Man., 6th ed., 582; Arthur, Fl. Iowa. 33; Hitchcock, Pl. Ames, 523; MacMillan, Metas. Minn. Val., 96; Tracy, Fl. Mo., 92 ; Brendel, Fl. Peoriana, 62; Bruhin, Fl. Wis., 278.

Low ground, margins of streams and in swamps; not common. This and the following species are often referred to Eriophorum from which genus they differ principally in having the bristles to the akenes much shorter.

Ames, Hitchcock; Clinton, I896, Ball; Story county, June, I886, Fohnson; Scott and Muscatine counties, Barnes \& Miller; Decatur county, July 2, I896, Fitzpatrick; Fort Dodge, July 5, I897, Shimek; Peru, July 20, 1897, No. 394, Hollingsworth; Lebar, July 5, I897, Sample.

7. S. cyperinus (L.) Kunth. Enum., it, i70 (1837).

Eriophorum cyperinum L. Sp. Pl. 2nd ed., 77 (1762). 
Illus. Flora, I, 271, fig. 636; Gray's Man., 6th ed., 582; Arthur, Fl. Iowa, 33;

Hitchcock, Pl. Ames, 524; MacMillan, Metas. Minn. Val., 96; Brendel, Fl. Peoriana, 88; Wheeler, Fl. Milwaukee Co., Wis., 'r86: Rydberg, Fl.

Bl. Hills, S. D., 527; Fink, Iowa Acad. Sci., Iv, I05.

Habitat and range similar to the preceding from which it differs in having the spikelets in capitate clusters, ${ }_{36}$ and the bristles to the mature fruit much longer. A variable plant.

Iowa City, Hitchcock; Fayette county, I894, Fink; Jasper county, Aug., 1885, Fohnson; Scott and Muscatine counties, Barnes \& Miller; Charles City, Arthur.

\section{E R I O PH OR U M L. Sp. Pl. 52 (I 753).}

A small genus of perennial bog sedges restricted to the northern hemisphere. The perfect flowers are disposed in solitary, capitate or umbelled spikes, and are furnished;with a perianth of few or numerous bristles which are much elongated in fruit and very conspicuous, whence the popular name, Cotton-Grass.

Species about Io.

Illus. Flora, 7; Gray's Man., 6th ed., 5; $\Lambda$ rthur, Fi. Iowa, 2; MacMillan, Metas. Minn. Val., 5; Tracy, Fl. Mo., I; Brendel, Fl. Peoriana, 2; Web• ber, Fl. Neb., and Rep. I-IV, 2.

I. E. polystachyon L. Sp. Pl. 52 (I753).

Illus. Flora, I, 273, fig. 641; Gray's Man., 6th ed., 583; Arthur, Cont. Fl. Iowa, III; Hitchcock, Pl. Ames, 524; MacMillan, Metas. Minn. Val., 95; Bessey, Cont. Fl. Iowa, I23; Brendel, H1. Peoriana, 88; Wheeler,

Fl. Milwaukee Co., Wis., I86; Fink, Iowa Acad. Sci., Iv, I05.

Swamps, throughout the northern and eastern portions of the state. Quite variable in regard to width of leaves, size of spikes, and length of bristles. The latter are usually a white, but forms were collected by the author in Emmet county with the bristles slightly russet-tinged, and a similar form was collected by Prof. B. Fink in Fayette "county. The color, though similar, is much lighter than that of E. russeolum Fries. 
Ames, June, I870, Arthur; Emmet and Kossuth counties, numerous collections, Cratty; Fremont county, I894, Fink; Rock Creek tp., Jasper county, April Io and May 29, I896, Fohnson; Eldridge, Scott county, Barnes \& Miller.

2. E. GRACILE Koch. Cat. II, 259 (I80o).

E. gracile var. paucinervium Eng., Gray's Man., 2nd ed., 502 ( $185_{2}$ ).

Illus. Flora, I, 273, fig. 642; Gray's Man., 6th ed., 583; Arthur, Cont. Fl.

Iowa, v; MacMillan, Metas. Minn. Val., 94; Tracy, Fl. Mo., 92 ; Brendel, Fl. Peoriana, 62; Hale, Add. Fl. Wis., 5; Rydberg, Fl. Sand Hills, Neb., I84.

A slender bog species with spikes one-half the size of those of the preceding species, the bristles shorter. Our plant is what was formerly called the var. paucinervium Eng. The plant is also common in northern Europe.

Emmet county, May, I883, Cratty; Clarion, Wright county, May, i886, Rev. E. P. Childs.

H E M I C A R P H A Nees. \& Arn. Ed. New. Phil. Jour., xviI, 263 ( I 834 ).

Low, tufted sedges, closely related to Scirpus. About 3 species, of which 2.occur in the United States, the other in the trupics.

I. H. micrantha (Vahl.) Britton. Bull. Torr. Club., xv, IO4 (I888).

H. subsquarrosa Nees., in Mart., II, pt. I, 6I (I843).

Illus. Flora, I, 275, fig. 646; Gray's Man., 6th ed., 583; Arthur, Cont. Fl. Iowa, III; Hitchcock, Pl. Ames, 524; MacMillan, Metas. Minn. Val., 90; Tracy, Fl. Mu., 9r; Brendel, Fl. Peoriana, 6r ; Hale, Add. Fl. Wis., 5.

Wet, sandy soil; known only from the central and eastern portions of the state. A small, inconspicuous plant, easily overlooked by any but a careful observer. Sometimes confounded with Cyperus inflexus Muhl.

Iowa City, I887, Waterloo, I889, and Story county, rititchcock; Scott and Muscatine counties, Barnes \& Miller.

Notes.-I. Rhynchospora alba (L.) Vahl. and R. capillacea Torr. will probably yet be found in Iowa. The former species is reported from Minnesota, Illinois, and Kansas; the latter from Minnesota, Illinois, Kansas, and South Dakota. 
2. Cladium mariscoides (Muhl) Torr. Ann. Lyc. N. Y., II, 372 (1836), is credited to Iowa in Gray's Manual, 6th ed., 586 , and in the Illustrated Flora, $\mathrm{I}, 28 \mathrm{I}$. I have been unable to find an Iowa specimen of this plant in any collection in the state, nor can one be found in herbaria of the State University of Minnesota, the Missouri Botanical Gardens, the Gray herbarium, nor the herbarium of the Columbia University, New York City. Dr. Britton writes me that he took the Iowa range of the plant from Gray's Manual. It is very doubtful whether the plant has been detected within our limits, but subsequent research may yet bring it to light. Mr. A. A. Heller writes me from Minneapolis that they have Minnesota specimens in the State University herbarium. It is also reported from Wisconsin by Bruhin, and from Illinois by Brendel.

S C L E R I A Berg: Kongl. Acad. Sv. Handl., xxvi, I42 ( 765 ).

A large genus of some Ioo species, of which number Io occur in the eastern United States. Annuals or perennials.

Illus. Flora, 6; Gray's Man., 6th ed., 63; Arthur, Fl. Iowa, I; MacMillan, Metas. Minn. Val., 2; Tracy, Fl. Mo., I.

I. S. triglomerata Michx. Fl. N. A., il, I68 ( 1803 ).

Illus. Flora, I, 282, fig. 663; Gray's Man., 6th ed., 586; Arthur, Fl. Iowa, 33; MacMillan, Metas, Minn. Val., I05; Tracy, Fl. Mo., 92; Brendel, Fl. Peoriana, 62; Bruhin, Fl. Wis., 278.

Rare in the central, eastern, and southern portions of the state; low ground and thickets. The conical, bright white akenes are exposed in the mature plant.

Charles City and Elmira, I889, Hitchcock; Grinnell, June, I886, Fohnson; Wild Cat Den, Muscatine county, Barnes \& Miller; Charles City, I88I, Arthur; Decatur county, in flower, June 8, and in fruit July 2, I897, Fitzpatrick.

Note-Scleria verticillata Muhl. has been reported from Minnesota, Illinois, and Kansas, and Prof. L. H. Pammel tells me he has collected it near La Crosse, Wisconsin. It probably occurs in the eastern part of our state.

\section{A REX L. Sp. Pl., 972 (I753).}

A vast and difficult genus which contains about two-thirds of all our sedges. The unisexual, monœcious or diœcious flowers present little variation, hence the specific characters 
are mostly founded on the scales, mature fruit, and the character and disposition of the spikes, and even here the diversity is so small when compared with the number of species as to render the genus an exceedingly difficult one for the student. In height our species are from a few inches to about four feet. Most of these plants grow somewhat scattered, interspersed with the grasses; some are extensively stoloniferous, forming patches, while others grow in large and dense tufts. The greater number prefer damp situations, growing in marshes and swales, or along the margins of ponds and streams. Some occur only in timber, while a few delight in a very dry soil and assist in forming a scant covering for sterile knolls and hillsides.

Dr. C. E. Bessey in the report of the Iowa Agricultural College for 187 I published the first Contribution to the Flora of Iowa, in which is given a short list of the sedges then known to the state. In the Flora of Iowa, a catalogue of the flowering plants prepared by Dr. J. C. Arthur for the Centennial Commission, is given a more complete list of these plants. To this latter publication Dr. Arthur made several additions, and Prof. A. S. Hitchcock, formerly of Ames, gave some additional species in a paper published in the Bulletin of the Torrey Botanical Club, and in his catalogue of the Plants of Ames. The number of species and varieties of the genus Carex noted in these publications is as follows:

$$
\begin{aligned}
& \text { Arthur, Cont. Fl. Iowa, . . . . . . . I I (I876), } 39
\end{aligned}
$$

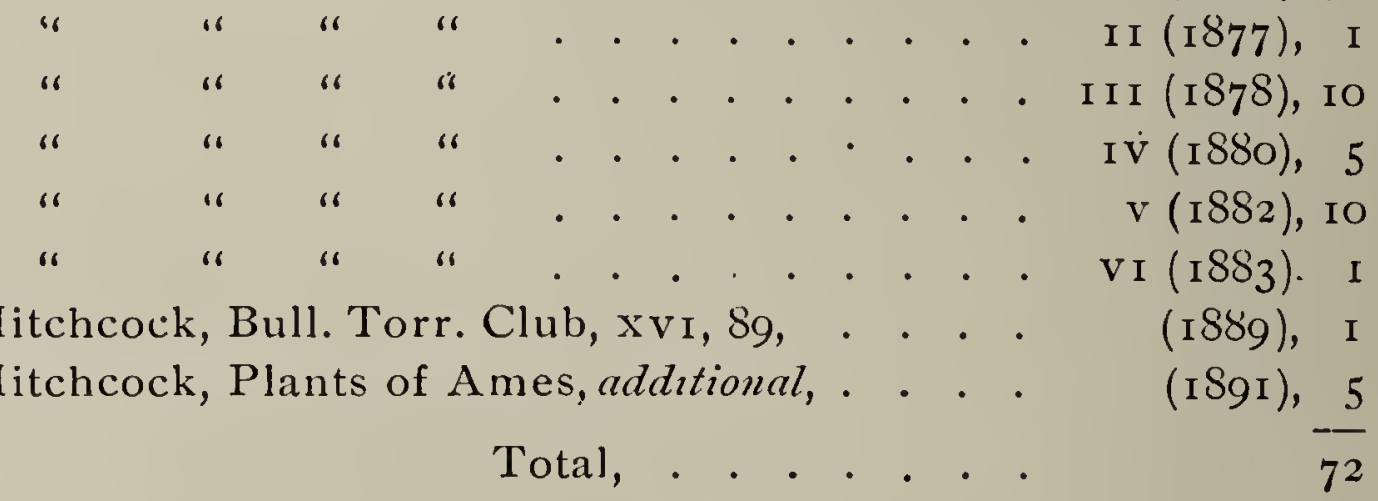

This number should be somewhat reduced as several of the varieties included in the above estimate are no longer recognized. 
The following species of the Iowa flora are also natives of Europe, and it is a noticeable fact that they are mostly high northern forms:

Carex stenophylla Wahl.

Carex chordorrhiza Linn. f.

Carex filiformis L.

Carex riparia W. Curtis.

Carex fusca All

Carex limosa $\mathrm{L}$.

Carex teretiuscula Good.

The genus contains over I, ooo species, of which number North America, north of Mexico, contains over 300.

Illus. Flora, 20.5; Gray's Man., 6th ed., I33. Species and varieties catalogued in Arthur, Cont. Fl. Iowa, I-VI, 66; Mac Millan, Metas. Minn. Val., 60; Tracy, Fl. Mo., 72: Bessey, Cont. Fl. lowa, I5; Brendel, Fl. Peoriana (including the state), 76; Smythe, Pl. Kansas, 67; Upham, Fl. Minn., 89; Bruhin, Ver. FI. Wis., 69; Webber, Fl. Neb. and Rep. I-Iv, 45; Rydberg, Fl. Bl. Hills, S. D., I9; Williams, Grass. and For. Pl. Daks., I9: Fink, Fl. Fayette, Iowa, 19.

I. C. intumescens Rudge. Linn. Trans., vil, 97 (I804).

Illus. Flora, I, 293, fig. 675; Gray's Man., 6th ed., 592; Arthur, Fl. Iowa, 34 ; Hitchcock, Pl. Ames, 524; MacMillan, Metas. Minn. Val., I29; Tracy, Fl. Mo., 93; Wheeler, Fl. Milwaukee Co., Wis., i87.

Rare in low ground. This probably includes all of the Iowa plants heretofore referred to C. folliculata L. This latter species is yellowish colored, especially the fertile spikes, the perigynia less inflated, and probably does not range farther west than Michigan. C. intumescens Rudge is green throughout, the perigynia much inflated.

Ames, Arthur; Story county, Hitchcock; Shelby county, July, I895, Fitzpatrick.

2. C. Asa-grayi Bailey. Bull. Torr. Club , xx, 427 (i893).

C. grayi Carey, Sill. Jour., 2nd ser., Iv, 22 ( 1847 ), not C. grayana Dew. (I834).

Illus. Flora, I, 293, fig. 576; Gray's Man., 6th ed., 592; Arthur, Cont. Fl. Iowa, III; Hitchcock, Pl. Ames, 524 ; Brendel, Fl. Peoriana, 63 ; Bruhin, Zwei. Nach. Fl. Wis., 643 . 
A very striking plant, well distributed throughout the southern and eastern portions of the state. The perigynia crowded in globose heads, otherwise much resembling C. intumescens Rudge.

Johnson county, I894, and Keokuk, I895, Shimek; Ames, Hitchcock; Richland tp., Jasper county, July 4, I884, the hispid form, Norris, and I886, Fohnson; Clinton, Scott, and Muscatine counties, frequent, Barnes \& Miller; Appanoose county, July 4, I889, Fitzpatrick.

3. C.. Lupulina Muhl. Schk. Riedg., il, 54 (i8o6).

Illus. Flora, I, 294, fig. 678; Gray's Man., 6th ed, 593: Arthur, Fl. Iowa, 34; Hitchcock, Pl. Ames, 524; MacMillan, Metas. Minn. Val., I29; Tracy, Fl. Mo., 93; Brendel, Fl. Peoriana, 63; Wheeler, Fl. Milwaukee Co., Wis., 187; Bot. Surv. Neb., IV., 45; Fink, Iowa Acad. Sci., Iv, I05.

Margins of swamps; throughout, but not plentiful. The more common form has the spikes peduncled (var. pedunculata Dew.). C. lupuliformis Sartwell, is reported trom Minnesota and possibly occurs within our limits.

Emmet county, south shore of Iowa Lake, I896, Cratty, Johnson county, I894, Shimek, and Iowa City, I887, Hitchcock; Fayette county, I894, Fink, Mississippi bottoms, La Crosse, Wis., I887, Pammel; Ames, I886, Hitchcock; Jasper county, July 4, I884, and May, I886, Fohnson; Clinton, Scott and Muscatine counties, Barnes \& Miller; Charles City, Aug., 1875, Arthur; Johnson county, July, 1897, Misses Finch \& Cavanagh; Keokuk, June I, I897, Shimek; Ames, July I894, Stewart.

4. C. monile Tuck. Enum. Meth. 20 (I843).

Illus. Flora. I, 297, fig. 688; Gray's Man. 6th ed., 594; Arthur, Cont. Fl. Iowa, v; MacMillan, Metas. Minn. Val., I28; Tracy, Fl. Mo., 94; Brendel, Fl. Peoriana, 63; Wheeler, Fl. Milwaukee Co., Wis., IS7.

Very low ground, growing in dense tufts; the whole plant light colored, especially the fertile spikes.

Emmet county, I887, Cratty; Iowa City, a form much resembling C. utriculata Boott, Hitchcock; Richland tp., Jasper county, May 29, I886, Norris; Moscow, Muscat ine county and Noels, Scott county, Barnes \& Miller. 
5. C. tuckermani Dezu. Am. Jour. Sci., xilix, 48 (1845). Illus. Flora, I, 298, fig. 689; Gray's Man., 6th ed., 594; Tracy, Fl. Mo., 95; Brendel, Fl. Peoriana, 88 ; Upham, Supl. Fl. Minn., 49; Bruhin, Fl., Wis., 280 .

Low swampy ground, rare; not before reported from lowa. Grinnell, collected about I887, by Prof. H. W. Norris, and now in the herbarium of the Iowa Agricultural College. Its southern range recorded in our text books is New Jersey, Michigan, and Minnesota. The author has a specimen in his herbarium collected in Illinois many years ago by Dr. S. B. Mead, and it is reported from Missouri by Prof. T'racy.

6. C. Retrorsa Schwein. Ann. Lyc. N. Y., I, 70 (IS24).

Illus. Flora, I, 298, fig. 69I; Gräy's Man., 6th ed., 595; Arthur, Cont. F1 Iowa, v; MacMillan, Metas. Minn. Val., r27; Brendel, Fl. Peoriana, 88; Hale, Add. Fl. Wis., 5; Rydberg, Fl. Bl. Hills, S. D., 528; Fink, Iowa Acad. Sci., IV, I05.

Low ground in woods and along the margins of streams and sloughs; northern half of the state, rare. This is sometimes found growing with C. Iupulina Muhl. between which hybrids have been found in New York and Michigan and probably occur within our limits.

Estherville, I881, and Iowa Lake, I896, Cratty; Fayette county, I895, Miss Ona M. Rounds.

7. C. Lurida parvula (Paine) Bailey. Bull. Torr. Club, $\mathrm{xx}, 4 \mathrm{I} 8$ ( I 893 ).

C. tentaculata var. parvula Paine, Cat. Oneida Pl., I05 (I865).

Illus. Flora, I, 297; Hitchcock, Pl. Ames, 524.

Sloughs, very rare, Ames, I886, Hitchcock. This is the $C$. lurida of Hitchcock's Plants of Ames, 524, a specimen of which is now in the Iowa Agricultural College herbarium.

"Low-(8-16 in. high), very slender, with one or two spikes which are half or less the size of those in the type, sessile, or very nearly so; peryginia not more than half the size of those in the common form." Prof. L. H. Bailey in Bull. Torr. Club. l. c. 
8. C. hystricina Muhl. Willd. Sp. Pl., iv, 282 (i805).

Illus. Flora, I, 300, fig. 695; Gray's Man., 6th ed., 596; Arthur, Fl. Iowa, 34 ; Mac Millan, Metas. Minn. Val., I27; Tracy, Fl. Mo., 93; .Higley \& Raddin, Fl. Cook Co., Ills., I31; Bessey, Cont. Fl. Iowa, I24; Bruhin, Fl. Wis., 28o; Rydberg, Fl. Sand Hills, Neb., 184; Webber, Fl. Neb., 98.

Margins of streams and ponds; rather common throughout. C. pseudo-cyperus L. has been reported from this state, but specimens which I have seen so labelled I consider forms of the above.

Charles City, June, I875, Arthur; Estherville, I882, and Spirit Lake, July 29, I896, Cratty; Johnson county, 1887 , Hitchcock, and I894, Shimek; Spirit Lake, July 24, I883, Arthur; Grinnell, June, I885, Norris, and I886, Fohnson; Scott and Muscatine counties, Barnes \& Miller; Granite, June, I897, Shimek.

9. C. comosa Boott. Linn. Trans., xx, il 7 ( 1846 ).

C.pseudo-cyperus var. comosa Boott, Bot. Cal. II, 252 ( 1880 ).

C. pseudo-cyperus var. americana Hochst., Herb. Unio. Itin. (I837).

Illus. Flora, I, 30I, fig. 698; Gray's Man., 6th ed., 596; Arthur, Cont. Fl.

Iowa, v; MacMillan, Metas. Minn. Val., I26; Brendel, Fl. Peoriana, 63; Bruhin, Fl. Wis., 28o; Bot. Surv. Neb., III, 16.

Central and northern portions of the state; sloughs and margins of ponds. The large, nodding, comose spikes render this a very conspicuous plant.

Emmet county, I89I, Cratty; Cedar Rapids, Hitchcock; borders of lagoons along Cedar River, Muscatine county, Barnes \& Miller.

Io. C. squarrosa $L$. Sp. Pl., iI, 973 (I753).

Illus. Flora, 3or, fig. 700; Gray's Man., 6th ed., 596; Arthur, Cont. Fl. Iowa, III; MacMillan, Metas. Minn. Val., I26; Tracy, Fl. Mo., 94; Brendel, Fl. Peoriana, 63; Bruhin, $Z$ wei. Nach. Fl. Wis., 643; Webber, App. Fl. Neb., 23.

Rare in swamps; differs from the following species, which has generally been considered a synonym, in its lighter green color, narrower leaves, rarely more than 2 lines wide, and linear-oblong akene. Widely distributed throughout the Misssissippi valley. 
Appanoose county, July, I896, Fitzpatrick; near Skunk River, Jasper county, July 3, I886, Norris.

II. C. Typhinoides Schwein. Ann. Lyc., I, 66 ( 1824).

C. squarrosa Gray's Man., 6th ed., 596 (1890), in part.

C. squarrosa var. typhinoides Dewey, Am. Jour. Sci., XI, 3 I6 (I\$26).

- Illus. Flora I, 302, fig. 701.

This species, not before reported from Iowa, closely resembles C. squarrosa L. from which it is distinguished by its darker green leaves, 4 to 5 lines wide, and the broader akene which is 3 angled, ovoid elliptic, with concave sides It occurs in swamps in the eastern part of the state, and includes many of the Iowa forms heretofore referred to the preceding species.

Fredericksburg, Chickasaw county, Miss Hozve; banks of the Wapsipinicon, Scott county, July, I896, and Clinton and Muscatine counties, usually growing with C.asa-grayi Bailey, Barnes \& Miller; Mississippi bottoms, Oquawka, Illinois, Patterson.

\section{I2. C. Trichocarpa Muhl. Willd. Sp. Pl., iv, 302 (I805)}

C. trichocarpa var. imberbis Gray's, Man., 5th ed., 597 (1867).

C. trichocarpa var. dezveyi Bailey, Bot. Gaz., x, ( 1883 ),

C. trichocarpa var. laviconica (Dew.) Hitchcock. Trans. St. Louis Acad. Sci., 524 (1891).

Illus. Flora, I, 302, fig. 702; Gray's Man., 6th ed., 598; Arthuı, Cont. Fl. lowa, Iv; Hitchcock, Pl. Ames, 524; MacMillan, Metas. Minn.Val., I24; Tracy, Fl. Mo., 94; Brendel, Fl. Peoriana, 63; Webber, Pl. Neb., 98.

Sloughs and margins of ponds and streams; common and very variable. We have besides the type the forms previously called var. imberbis and var. deweyi, of which the latter at least, seems worthy of varietal recognition.

Estherville, Emmet county, June I8, I882, the pubescent form, Cratty; Iowa City, Hitchcock; Johnson county, I894, Shimek; Ames, I88o, Bessey, and r886, Hitchcock; West Davenport, I895, and Muscatine county, the glabrous form, Barnes \& Miller; Shelby county, r894, a form with pubescent perigynia, but the long, wide-spreading teeth like those 
of the next species, Fitzpatrick; Poweshiek county, I885, Norris, and I886, Fohnson; Granite, Lyon county, June, I897, a form approaching the next species, and Keokuk, June I, I897, a very slender form with smooth peryginia, Shimek; Ames, May 22, I877, Arthur.

I3. C. ARistata R. Br. Rich. Bot. App., 751 (1823).

G. trichocarpa var. aristata Bailey, Bot. Gaz., x, 293 (1885).

Illus. Flora, I, 302, fig. 703; Gray's Man., 6th ed., 598; Hitchcock, Pl. Ames' 524, and Bull. Torr. Club., xvi, 70; MacMillan, Metas. Minn. Val., 124; Tracy, Fl. Mo., 92; Bruhin, Fl. Wis., 280; Williams, Grass. \& For. Pl. Daks., 42.

Margins of ponds and streams; probably throughout the state but not common. This and the preceding species seem to run together.

Emmet county, I878, Cratty; Story county, Hitchcock; Hamilton county, I884, Rolfs; Johnson county, I894, Fitzpatrick; High Bridge, Dallas county, July 6, I897, and Keokuk, June I, I897, Shimiek. The latter approaches the preceding species.

I4. C. Riparia $W$. Curtis. Fl. Lond., iv, Pl., 60 (I82 I).

Illus. Flora, I, 303, fig. 704; Gray's Man., 6th ed., 598; Arthur, Cont. Fl. Iowa, Iv; Hitchcock, Pl. Ames, 524: MacMillan, Metas. Minn. Val., 124; Tracy, Fl. Mo., 94; Brendel, Fl. Peoriana, 63; Bruhin, Fl. Wis, 280 .

Sloughs, probably throughout the state, but not very plentiful. The perigynia dark colored and polished at maturity. So far as I have observed this species it rarely flowers or fruits.

Grinnell, 1877, Fones; Emmet county, 1878, Cratty; Richland tp., Jasper county, May, 1886, Fohnson; Story City, June 7, 1897, No. 422, Pammel \& Beyer.

I5. C. Shortiana Deze. Am. Jour, Sci., xxx, 6o( 1836 ). Pl. II.

Illus. Flora, I, 303, fig. 706; Gray's Man., 6th ed., 596; Tracy, Fl. Mo., 94 ; Brendel, Fl. Peoriana, 62; Webber, Fl. Neb., 98.

Rare in moist woods and thickets, eastern part of the state. Not before reported from Iowa. A very distinct species. 
Ravines at Wild Cat Den, Muscatine county. June, I895. Barnes \& Miller; Keokuk, June I, I897, Shimek.

Note.-In Upham's Flora of Minnesota, p. I5s, Garex houghtoni Torr Cyp., $4^{1} 3(1836)$ is credited to this state.- "Council Bluffs, Iowa, Geyer.' Search has been made in the herbaria of the University of Minnesota and" of the Missouri Botanical Gardens for an Iowa specimen, but without suc-

cess. I have been unable to find Prof. Upham's authority for the statement. This species is reported from Minnesota, Wisconsin, Kansas, and Nebraska.

r6. C. Lanuginosa Michx. Fl. N. A., il, i 75 (i803).

C. filiformis var. latifolia Boeckl. Linn., $\mathrm{xLI}, 309$ (1875).

G. filiformis var. lanuginosa B. S. P. Prelim. Cat. N. Y., 63 (1888).

Illus. Flora, I, 305, fig. 711; Gray's Man., 6th, ed. 597; Arthur, Fl. Iowa, 34; Hitchcock, Pl. Ames, 524; MacMillan, Metas. Minn. Val., 125; Bessey, Cont. Fl Iowa, 24 ; Brendel, Fl. Peoriana 63; Rydberg, Fl. Sand Hills, Neb., I85: Williams, Grass. \& For. Pl. Daks. 42.

Low ground around marshes; throughout the state. The spikes are usually longer than those of $C$. filiformis $\mathrm{L}$. which it much resembles.

Emmet county, i878, Cratty; Ames, i886, and Hancock county, Hitchcock; Shelby county, May, 1894, Fitzpatrick; Grinnell, r885, Norris; Scott and Muscatine counties, Barnes \& Miller; Missouri Valley, June 2 I, I897, a very tall, loosely flowered form with spikes I $1 / 2$ inches long, Pammel.

I7. C. filiformis $L$. Sp. Pl., ir. 976 ( I753).

Illus. Flora, I, 305, fig. 712 ; Gray's Man., 6th ed., 597; Hitchcock, Pl. Ames, 524; MacMillan, Metas. Minn. Val., 125; Tracy, Fl. Mo., 93; Brendel, Fl. Peoriana, 63; Hale, Add. Fl. Wis., 5; Webber, Fl. Neb. 98.

Rare in bogs. This and a few other sedges, grasses, and aquatic mosses form by their long, interlacing roots the tough sod which covers the surface of the quaking bogs in the northwestern portion of the state. This sedge flowers and fruits here only under the most favorable conditions of moisture and temperature. Also a native of northern Europe.

Emmet county, r878, Cratty; Ames, Hitchcock; Grinnell, I 885, Norris.

I8. C. Fusca All. Fl. Ped. Ir, 269 ( I 785 ).

C. buxbumii Wahl. K. Acad. Handl. xxrv. 163 ( 1803 ).

Illus. Flora, I, 307, fig. 718; Gray's Man., 6th ed., 599; Arthur, Fl. Iowa, 34;

Mac Millan, Metas. Minn. Val., I23; Brendel, Fl. Peoriana, 62. 
Not rare in low ground around sloughs; a beautiful species, the purple scales being very conspicuous. It also is a native of northern and central Europe.

Emmet county, I878, Cratty; Ames, Hitchcock; Charles City, Arthur; Grinnell, May, I886, Norris; Noels and Eldridge, Scott county, I895, Barnes \& Miller; High Bridge, Dallas county, July 6, I897, a slender form 2 feet high, Shimek; Story City, June 7, 1897, No. 421, Pammel \& Beyers.

I9. C. stricta Lam. Encyc. Meth., III, 387 ( I789).

Illus. Flora, I, 308, fig. 719; Gray's Man., 6th ed., 599; Arthur, Fl. Iowa, 34 ; Hitchiock, Pl. Ames, 524; MacMillan, Metas. Minn. Val., I23; Tracy, Fl. Mo., 95; Bessey, Cont. Fl. Iowa, 123; Brendel, Fl. Peoriana, 62; Wheeler, Fl. Milwaukee Co., Wis., I $S_{7}$; Rydberg, Fl. Black Hills, S. D., 527 ; Fink, Iowa Acad. S'ci., IV, 105.

Sloughs and margins of ponds and streams throughout; common and very variable.

Fayette county, I895, Fink; Johnson county, I893, and Cedar Rapids, I895, Shimek; Ames, Hitchcock; Emmet county, Cratty; Charles City, Arthur; Iowa City, Hitchcock; Grinnell, I886, Norris; Decatur county, May, I897, probably this, the plant in flower only, Fitzpatrick; Spirit Lake, June, 25, I88i, Arthur; Marshalltown, May, r897, Ball.

20. C. stricta angustata Bailey in Gray's Man., 6th ed., 600 ( I 890).

C. augustata Boott, in part. Hook. Fl. Bor. Am. II, 2 I 8 ( $\left.18_{4} \mathrm{O}\right)$,

Illus. Flora, I, 2o8; Bailey in Gray's Man., I. c.; Smythe, Pl. Kansas, 23;

Williams, Grass. \& For. Pl. Daks., 43.

Swales, central and eastern portions of the state; distinguished by its stricter habit, longer and more slender spikes, and narrow scales.

Eldridge, Scott county, June, I895, frequent; Barnes \& Miller; Johnson county, May, I895, Shimek.

2r. C. haydeni Dew. Am. Jour., 2nd ser., xvili, IO3 ( I 854).

C. aperta Carey in Gray's Man., Ist ed., 547 (i $8_{4} 8$ ), not Boott ( $18_{40}$ ).

C. stricta var. decora Bailey, Bot: Gaz., xin, 85 (1888).

Illus. Flora, I, 308, fig. 970; Gray's Man., 6th ed., 60o; Arthur, Fl. Iowa, 34;

Tracy, Fl. Mo., 92 ; Brendel, Fl. Peoriana, 88; Hale, Add. Fl. Wis., 5 ;

Williams, Grass. \& For. Pl. Daks., 43. 
Margins of ponds and streams; well distributed, but most common in the eastern half of the state. This and the two preceding are very variable in regard to height of plant, length of spikes, and comparative length of scales and perigynia.

Emmet county, i878, Cratty; Fayette county, is95, Fink; Johnson county, I895, Shimek; Charles City, Arthur; Iowa City, Hitchcock; Grinnell, I885, Norris; Scott and Muscatine counties, Barnes \& Miller.

Note.-Carex aquatilis Wahl. has been reported from Iowa, (Fink, Proc. Iowa Acad. Sci., IV, IO5) but there is considerable doubt regarding the identification, as the plänts, specimens of which are in my herbarium, are in the early flowering state. It is more likely a form of C. stricta Lam. Mature fruiting specimens of the plant are very much desired.

22. C. limosa L: Sp. Pl., II, 977 (I753).

Illus.1Flora, I, 313, fig. 734; Bailey in Gray's Man., 6th ed., 602; Arthur, Cont.

Fl. Iowa, v; MacMillan, Metas. Minn. Val., I2 I; Brendel, Fl. Peoriana, 62 ; Hale, Add. Fl. Wis., 5 ; Bot. Surv. Neb., III, 5.

Very rare in bogs; the nodding spikes on filiform peduncles give this sedge a very graceful appearance. Also a native of northern Europe.

Emmet county, in a large marsh on the n. e. $1 / 4$, sec. I3, Armstrong Grove tp., June, x878, Cratty.

23. C. Davisir Schruein. \& Torr. Mon. Car., 326 (I825).

Illus. Flora, I, 3I8, fig. 75I; Gray's Man., 6th ed., 605; Arthur, Fl. Iowa, 34; Hitchcock, Pl. Ames, 525; MacMillan, Metas. Minn. Val., I 2o; Tracy, Fl. Mo., 92 ; Brendel, Fl. Peoriana, 62; Hale, Add. Fl. Wis., 5.

Quite common in woods in the central and eastern portions. Several specimens of this plant have been seen in Iowa collections labelled C. miliacea Muhl. (now C. prasina Wahl:). 'I'his latter species may, however, yet be found within our limits, having been reported from Ramsey county, Minnesota (Kossube).

Johnson county, I894, Shimek, and I895, Fitzpatrick; Ames and Iowa City, Hitchcock; Jasper county, I886, Norris; Noels, Scott county, and Moscow and West Liberty, Muscatine county, Barnes \& Miller; Keokuk, June I, I897, Shimek. 
24. (.. Longirostris Torr. Schwein. Ann. Lyc. N. Y., I, 7 I (I824).

Illus. Flora, I, 319, fig. 752; Bailey in Gray's Man., 6th ed., 603; Arthur,

Fl. Iowa, 34; MacMillan, Metas. Minn. Val., I2r; Bessey, Cont. Fl. Iowa, 124; Brendel. Fl. Peoriana, 63; Bruhin, Fl. Wis., 280: Webber, Fl. Neb., 98; Rydberg, Fl. Bl. Hills, S. D., 528.

Common in woods; a very distinct and graceful species.

Charles City, June, I875, Arthur; Clinton county, I878, Butler; Emmet county, various collections, Cratty; Fayette county, I895, Fink; Ames, Hitchcock; Jasper county, May, I886, Norris; Big Rock, Scott county, Barnes \& Miller.

25. C. grisea Wahl. K. Acad. Handl, xxiv, I54 ( I803).

Illus. Flora I, 321, fig. 759; Gray's Man., 6th ed., 605; Arthur, Fl, Iowa,

34; Hitchcock, Pl. Ames, ; 525; MacMillan, Metas. Minn. Val., 120;

Tracy, Fl. Mo., 93; Bessey, Cont. Fl. Iowa, I24; Brendel, Fl. Peoriana.

62; Webber, Fl. Neb., 98.

Rich woods, probably throughout the state.

Ames and Iowa City, Hitchcock; Charles City, I885, Arthur; Lynnville, Jasper county, May, I886, Norris; bank of Wapsipinicon, Scott county, I895, Barnes \& Miller.

26. C. amphibola Steud. Syn. Pl. Cyp., 234 (1855). Pl. III.

C. grisea var. angustifolia Boott, Ill., 34 ( 1858 ).

Illus. Flora, I, 321, fig. 760; Bailey in Gray's Man., 6th ed., 605.

Northern and eastern portions of the state; rather rare in moist soil, especially in woods along streams. Leaves I to 2 lines wide, being much narrower than those of the preceding species which it much resembles. Not before reported from Iowa.

'Emmet county, rare, I88o, Cratty; Scott county, I895, frequent, Barnes \& Miller.

27. C. granularis Muhl. Willd. Sp. Pl., iv, 279 (1805).

Illus. Flora, I, 322, fig. 763; Gray's Man., 6th ed., 605; Arthur, Cont. Fl.

Iowa, IV; MacMillan, Metas. Minn. Val., I 20; Tracy, Fl. Mo., 93;

Brendel, Fl. Peoriana, 62; Wheeler, Fl. Milwaukee Co., Wis. 187 ; Bot.

Surv. Neb., IV, 45 .

Central and southeastern; not common. 
Clinton county, I878, Butler; Johnson county, I894, Shimek. The staminate spike of the latter specimen prominently stalked, leaves 2-4 lines wide, the lower, fertile spike, distant.

28. C. Crawir Dezvey. Am. Jour. Sci., 2nd ser., II, 246 $(\mathrm{I} 846)$. Pl. iv.

Illus. Flora, I, 323, fig. 764; Bailey in Gray's Man., 6th ed., 606; MacMillan, Metas. Minn. Val., I I9; Hale, Add. Fl. Wis., 5; Rydberg \& Shear, Bull. No. 5, U. S. Dept. Agricul., 4I; Higley \& Raddin, Fl. Cook. Co., Ills. I33.

Prairies, rare; preferring rather moist ground. The whole plant, light colored, especially the wide leaves of the sterile shoots which are produced very freely from the stolons. Not before reported from Iowa.

Emmet county, I $1 / 2$ miles northeast of Armstrong, June, I 884 , Cratty. This is the only station known in the state but it probably occurs elsewhere in the northern portion along with C. meadii Dew., which is found in similar situations. Prof. Fitzpatrick collected a sedge in flower April 29, 1894, in Shelby county, which may prove to be this species.

29. C. conoidea Schkuhr. Ried, Nacht., 67 (I806).

Illus. Flora, I, 325, fig. 770; Bailey in Gray:s Man., 6th ed., 607; MacMillan, Metas. Minn. Val., I19; Tracy, Fl. Mo., 93; Brendel, Fl. Peoriana, 88.

Probably very rare within our limits; not before reported from Iowa.

Prairies near Noels, Scott county, May, I895, Barnes \& Miller. I also refer here an immature specimen collected by Dr. Arthur at Charles City in 1875 .

3o. C. Oligocarpa Schkuhr. Ried, Nacht., 58 (i8o6).

Illus. Flora, I, 32.5, fig. 77I; Gray's Man., 6th ed, 607: Arthur, Cont. Fl. Iowa, III; Tracy, Fl. Mo., 94; Brendel, Fl. Peoriana, 62; Bruhin, Zwei. Nach., Fl. Wis., 644 .

Rare in woods and thickets; central and eastern portion of the state. Leaves about I line wide, the sheaths smooth.

Hickory Grove, Scott county, May I2, r896, Barnes \& Miller; Rock Creek twp., Jasper county, May.29, 1886, Norris; Marshalltown, i897, Pammel.

IV-4 $3 \mathrm{E}$ 
3I. C. hitchcockiana Deze. Am. Jour. Sci. x. 274 (i 826 ).

Illus. Flora, I, 325, fig. 772; Bailey in Gray's Man., 6th ed., 607; Tracy, Fl.

Mo., 95; Brendel, Fl. Peoriana, 62; Bruhin, $Z$ wei. Nach., Fl. Wis., 643.

Not before reported from Iowa, and probably rather rare within our limits. It much resembles the preceding species, from which it is distinguished by its wider leaves and pubescent sheaths.

Richland twp., Jasper county, May 29, r886, Norris; High Bridge, Dallas county, July 6, I897, Shimek; in woods south of Iowa Lake, Aug. 29, I897, Pammel \& Cratty.

32. C. meadir Dezey, Sill. Jour. xuIII, 90 ( 1842 ).

C. tetanica var. meadii Bailey, Syn. Car. i 8 (I8So).

Illus. Flora, I, 327, fig. 776; Gray's Man., 6th ed., 609: Arthur, Fl. Iowa, 34; Hitchcock, Pl. Ames, 525; MacMillan, Metas. Minn., Val., i IS; Tracy, Fl. Mo., 93; Brendel, Fl. Peoriana, 62; Bruhin, Fl. Wis., 279; Webber, Fl. Neb., 98; Williams, Grass and For. Pl. Daks., 43.

Common on prairies, well distributed throughout the state. This sedge is of considerable value for pasturage, being greedily eaten by cattle. An attenuate form of this collected by the author in Emmet county in 1882 , and by F. W. Johnson in Poweshiek county, is the Carex meadii var. bebbii (Olney) Arthur, Cont. Fl. Iowa, V, 67 (1884). It seems to be only an occasional state caused by the plants growing among tall grasses in lower ground. The typical C. tetanica Schk., though reported from Iowa, has probably not yet been collected within our limits. Specimens so labelled in the I. A. C. herbarium are referred to $C$. meadii Dew. by Prof. Bailey. Emmet county, 1878, Cratty; Chariton, Shepherd; Ames and Iowa City, Hitchcock; Johnson county, May, I895, Fitzpatrick; Grinnell, May 25, I885, Norris, and i886, Fohnson; Scott and Muscatine counties, I893, common, Barnes \& Miller; Decatur county, May, I895, Fitzpatrick; Hancock county, June, r875, Arthur.

\section{C. laxiflora Lam. Ency. Meth. ili, 392 (I789).}

Illus. Flora, I, 327, fig. 777; Gray's Man., 6th ed., 607; MacMillan, Metas. Minn. Val., I19; Tracy, Fl. Mo., 93; Brendel, Fl. Peoriana, 62; Bruhin, Fl. Wis., 279; Webber, Fl. Neb., 98; Fink, Proc. Iowa, Acad. Sci., Iv, I05. 
Woods, less common than the following variety. Not before reported from Iowa.

Iowa City, I895, Shimek; Fayette, I895, Fink; Johnson county, I895, Fitzpatrick; Scott and Muscatine counties, Barnes \& Miller; Decatur county, May, I897, Fitzpatrick; Keokuk, June I, I897, Shimek; Marshalltown, May I, I 897 , Pammel; Ames, May 26, I897, a form very close to the next, Combs \& Pammel.

34. C. laxiflora blanda (Dew.) Boott. Ill. Car. 37 $\left(\mathrm{I} 85^{8}\right)$.

C. blanda Dewey, Am. Jour. Sci. x, 45 ( 1826 ).

C. laxiflora var. strictula Carey, Gray's Man., 2nd ed., 524 (1852).

Illus. Flora, I, 327; Gray's Man., 6th ed., 607; Arthur, Fl. Iowa, 34; Tracy,

Fl. Mo., 93; Rydberg, Fl. Bl. Hills, S. D., 52S; Higley \& Raddin, Fl.

Cook Co., Ills., I34.

The most common form of the species; in woods, probably throughout the state.

Charles City, June, I875, Arthur; Johnson county, I894, Shimek; Jasper county, I886, Fohnson; Emmet county, I885. Cratty; Scott and Muscatine counties, Barnes \& Miller; Des Moines, May 15, 1897, L. H. \& Emma Pammel.

35. C. digitalis copulata Bailey, Mem. Torr. Club, I, 47 (I889). Pl. V.

Illus. Flora, I, 328; Gray's Man., 6th ed., 6o8; Beal \& Wheeler, Fl. Mich., I 53 .

Rare in the southeastern part of the state, not before reported from Iowa.

Ravines at Wild Cat Den, Muscatine county, I896, Barnes \& Miller. This extends its range several hundred miles to the westward, it having heretofore been reported only from Michigan and Southern Ontario. It is very probable that $C$. digitalis Willd. occurs in the state. It is a smaller plant, with very narrow leaves $\mathrm{I}-2$ lines wide.

36. C. albursina Sheldon, Bull. Torr. Club, xx, 284 ( 1893 ).

C. laxiflora var. latifolia Boott. Ill. Car. ( $\left.\mathrm{I}_{5} \mathrm{~S}\right)$ not C. latifolia Moench.

Illus. Flora, I, 329, fig. 78I; Gray's Man., 6th ed., 607; Arthur, Fl. Iowa, 34;

Hitchcock, Pl. Ames, 524; Tracy, F1. Mo., 93.

IV $-4 \quad 3 \quad \mathrm{E} 2$ 
Moist, rich woods; common in the central, southern and eastern portions of the state. Our widest-leaved species, the plants often a foot high, with leaves 4-Io lines wide. Though long considered a variety of C. laxiflora Lam., it seems to be worthy of specific rank. The name albursina, given to it by Mr. E. P. Sheldon, is in allusion to White Bear Lake, Minnesota.

Clinton county, 1878, Butler; Big Grove twp., Johnson county, 1894, Shimek; Kellogg, r876, Fones; Ames, Hitchcock, Peters; Wild Cat Den, Muscatine county, and Allen's Grove, Scott county, Barnes \& Miller; Richland twp., Jasper county, May, I886, Norris: High Bridge, Dallas county, July 6, I897, Shimek; Dallas Center, I897, a leaf specimen only, but probably this, Rhinehart.

Note.-C. plantaginea Lam. Encyc. III, 392 (I 789 ), has been reported from Iowa, but $I$ have been unable to find any authentic Iowa specimen. It closely resembles $C$. albursina Sheldon, in general appearance, but flowers before the dark green leaves are produced. It is reported from Wisconsin and Illinois.

37. C. setifolia (Dezu.) Britton. Illus. Flora, i, 332, fig. $790($ I 896$)$.

C. eburnea Boott. Hook. Fl. Bor. Am. Ir, 226 ( 1840 ).

C. alba var. setifolia Dew. Am. Jour. Sci., Ir, 3 I6 (1826).

Illus. Flora, 1. c.; Bailey in Gray's Man., 6th ed., 610; Arthur, Fl. Iowa, 34; Hitchcock, Pl. Ames, 525; MacMillan, Metas. Minn. Val, II8; Tracy, Fl. Mo., 93; Webber, Fl Neb., 98.

Rare in woods, preferring rather dry, sloping, and well shaded ground; the fruit black and shining when fully matured, and not falling till late in the autumn.

Clinton county, I872, Butler; Estherville, Emmet county, Iowa, I882, and Armstrong, Aug. 31, I897, Cratty; Jackson county, I 894, Shimek; Ames, Bessey, Hitchcock.

38. C. richardsoni R. Br. Richards, App. (Frank.) Journal, 75I (I823).

Illus. Flora, I, 332, fig. 792; Gray's Man., 6th ed., 6ro; Arthur, Cont. Fl. Iowa, Iv; MacMillan, Metas. Minn. Val., Ir 7 ; Tracy, Fl. Mo., 94; Brendel, Fl.Peoriana, 62; Hale, Add. Fl. Wis., 5; Rydberg, Fl. Bl. Hills, S. D., 527 . 
A very rare sedge occurring in dry ground.

Grinnell, I876, name of collector unknown, a single plant only in the I. A. C. herbarium.

39. C. pedunculata Muhl. Willd. Sp. Pl., iv, 222 (i805.)

Illus. Flora, r. 333, fig. 793; Bailey in Gray's Man., 6th ed., 6ro; Arthur, Cont. Fl. Iowa, III; MacMillan, Metas. Minn. Val., i 7 . Brendel, Fl. Peoriana, SS; Hale, Add. Fl. Wis., 5; Fink, Proc. Iowa Acad. Sci., Iv, 105 .

Dry ground in woods; rather rare in the southern and eastern portions of the state.

Clinton county, April 18, 1878, Butler; Fayette county, I895, Fink.

40. C. Pedicellata (Dezu.) Britton, Mem. Torr. Club, v, (I894).

C. communis Bailey, Mem. Torr. Club, I, 4 I (I889).

C. varia var. pedicellata Dew. Am. Jour. Sci., xI, I62 ( I 826).

C. varia Dew. Am. Jour. Sci., XI, IO2 (I826) not Muhl. (I805).

Illus. Flora, I, 333, fig. 794; Gray's Man., 6th ed., 612; Upham, Fl. Minn., I 57 ; Brendel, Fl. Peoriana, 87; Tracy, Fl. Mo., 95.

Rare in dry soil, eastern portion of the state; not before reported from Iowa. This species much resembles $C$. pennsylvanica Lam. but unlike the latter is not stoloniferous, the fertile spikes loosely flowered, and the whole plant taller and less strict in habit. This is the C.varia of Gray's Manual, 5th ed., p. 692, and of most catalogues published previous to I89o. The true $C$. varia Muhl. (C'. emmonsii Dew.) ought to be found within our limits.

Wild Cat Den, Muscatine county, 1893 , and Scott county, June, r897, Barnes \& Miller; Muscatine, I897, Ball.

41. C. Pennsylvanica Lam. Encyc. III, 388 (I789).

Illus. Flora, I, 333, fig. 795; Bailey in Gray's Man., 6th ed., 612; Arthur, Fl. Iowa, 34; MacMillan, Metas. Minn. Val., 117 ; Hitchcock, Pl. Ames, 525; 'Tracy, Fl. Mo., 94; Brendel, Fl. Peoriana, 62; Wheeler, Fl. Milwaukee County, Wis., I $8_{7}$; Rydberg, Fl. Sand Hills, Neb., I $8_{5}$; Williams, Grass and For. Pl. Daks., 43 .

High prairies and woods; the most common and the earliest of our sedges, the flowers appearing in April, the fruit a 
month later. Strongly stoloniferous, forming small patches, and furnishing considerable early pasturage.

Emmet county, I 878 and many later collections, Cratty; Fayette county, I895, Fink; Johnson county, 1875, Shimek; Charles City, May, I874, Arthur; Ledyard, Kossuth county, July, I897, Pammel; Iowa City, I887, Hitchcock; Ames, I891, Rolfs; Grinnell, I886, Norris; Scott and Muscatine counties, Barnes \& Miller; Decatur county, May, I897, Fitzpatrick. Prof. C. E. Bessey in June, I875, collected at Ames what I take to be a late flowering form of this species, with the strict leaves much exceeding the culm. The same form in flower was collected by Prof. B. Shimek in Lyon county, June, I897. Both these may prove to be something else, but further observations and more complete material are necessary.

42. C. pubescens Muhl. Willd. Sp. Pl., iv, 28 I (I805).

Illus. Flora, I, 336, fig. So2; Gray's Man., 6th ed., 613; Arthur, Cont. Fl. Iowa, v; Hitchcock, Pl. Ames, 525; MacMillan, Metas. Minn. Val., i 6 ; Tracy, Fl. Mo., 95; Brendel, Fl. Peoriana, 62; Wheeler, Fl. Milwaukee Co., Wis., 187 .

Rare in moist woods, central and southeastern portions of the state.

Iowa City, I887, Hitchook; Jasper county, I885, Norris; Scott and Muscatine counties, infrequent, Barnes \& Miller.

43. C. Jamesil Schwein. Ann. Lyc., N. Y., I, 67 (1824).

C. steudellii Kunth., Enum., II, 4 So (I 837 ).

Illus. Flora, I, 337, fig. So7; Gray's Man., 6th ed., 613: Swezey's Flow. Pl.

Neb., 15: Higley \& Raddin, Fl. Cook Co., Ills., i 36.

Rare in dry, rich woods and thickets, eastern portion of the state; not before reported from Iowa. An inconspicuous, grass-like species, the few-flowered spikes hidden among the leaves, and easily overlooked by any but an acute observer.

Wilton and Wild Cat Den, Muscatine county, June, I895, Barnes \& Miller.

44. C. Chordorrhiza Limn. f. Supl. 4I4 (I78I).

Illus. Flora, I, 34I, fig. S17; Bailey in Gray's Man., 6th ed., 614; Arthur, Cont. Fl. Iowa, v; MacMillan, Metas. Minn. Val., ıı6; Brendel, Fl. Peoriana, 88; Bruhin, Fl. Wis., 279. 
Very rare in cold bogs. The long creeping rootstocks each send up numerous culms to the height of 10 to 20 inches. This is an example of a high northern plant which barely comes within our limits. Also in northern Europe.

Emmet county, in a bog two miles north of Armstrong June, I 878 , the only locality known in the state, Cratty.

45. C. Stenophylla Wahl. K. Acad. Handl. ser. 2, xxiv, I 42 ( $\left.\mathrm{ISO}_{3}\right)$. Pl. vi.

Illus. Flora, I, 34I, fig. S9I; Gray's Man., 6th ed., 6I4; Arthur, Cont. Fl. Iowa, v, No. S6oa; MacMillan, Metas. Minn. Val., Ir5; Webber, Fl. Neb., 9S: Rydberg, Fl. Bl. Hills, S. D., 527; Shimek, Proc. Iowa Acad. Sci, IV, 74 .

Very dry ground on gravelly knoils. This plant, also a native of northern and central Europe, here finds its eastern limit in the United States. It ranges from Iowa to Minnesota, Nebraska, Kansas, Colorado and northward. So far as known it is the only strictly western species of the genus occurring within our limits. This is the C. siccata of Arthur's Cont. Fl. Iowa, v, ( IS82).

Estherville, June, I882, in very dry ground, forming a dense patch on school-house block, the station since destroyed; Lyon county, Aug. I, I896, very old plants, the perigynia turned black, slightly larger than in the Emmet county plant, Shimek. In June, I897, Prof. Shimek again collected this plant in the same locality, growing with Buffalo Grass (Bulbilis dactyloides ( Nutt.) Raf.

46. C. conjuncta Boott. Ill. Car., I 22 (r862).

Illus. Flora, I, 342, fig. S22; Gray's Man., 6th ed., 6I4; Arthur, Cont. Fl. Iowa, III; Hitchcock, Pl. Ames, 525; MacMillan, Metas. Minn. Val., I 5 ; Tracy, Fl. Mo., 93; Brendel, Fl. Peoriana, 62: Bruhin, Zwei. Nach. Fl. Wis., 643 .

Rare in woods, central and southern portions of the state. Johnson county, I895, Shimek; Story county, Hitchcock; Kellogg, June 1876 , collector unknown . 
47.

C. stipata Muhl. Willd. Sp. Pl. IV, 253 (I805).

Illus. Flora, I, 343, flg. 823; Gray's Man., 6th ed., 6I4; Arthur, Fl. Iowa, 33: MacMillan, Metas. Minn. Val., I 5; Tracy, Fl. Mo., 94; Brendel, Fl. Peoriana, 62; Wheeler, Fl. Milwaukee Co., Wis., I87; Rydberg, Fl. Sand Hills, Neb., 185; Williams, Grass. and For. Pl. Daks., 43; Fink., Proc. Iowa Acad. Sci., IV, I05.

Wet marshy ground, usually in woods; common throughout. The plants are very weak when growing in water, but in drier ground they are less flaccid, with narrower leaves.

Emmet county, 1882 , Cratty; Fayette county, r895, Fink; Iowa City, Hitchcock; Shelby county, 1894, and Johnson county, I895, Fitzpatrick; Jasper county, May, r886, Norris; Scott and Muscatine counties, Barnes \& Miller; Ames, Bessey; Keokuk, June I, '1897, Shimek.

48 C. crus-corvi Shuttlew. Kunze, Riedg., Suppl. I28 ( 1844$)$.

Illus. Flora, I, 343, fig. 824; Bailey in Gray's Man., 6th ed., 614; Arthur,

Cont. Fl. Iowa, II ; MacMillan, Metas. Minn. Val., II 5; Tracy, Fl. Mo., 92; Brendel, Fl. Peoriana, 62; Hale, Add. Fl. Wis., 5; Webber, Fl. Neb., 98 .

Low ground, southeastern section of the state; one of the most conspicuous species of the genus, and rather rare within our limits.

Clinton county, I878, Butler; Page county, 1888, Hitchcock; borders of Muscatine slough, Reppert; Muscatine Island, Louisa county, Aug. 7, r897, Shimek \& Meyers.

49. C. Teretiuscula Good. Trans. Linn. Soc., il, I67 ( I794.)

Illus. Flora, I, 344, fig. 827; Bailey in Gray's Man., 6th ed., 6r 4 ; Arthur, Cont. Fl. Iowa, Iv; MacMillan, Metas. Minn. Val., I14; Brendel, Fl. Peoriana, 62; Rydberg, Fl. Sand Hills, Neb., I 85 .

Rare in bogs; northern and central portions of the state. Also common in northern Europe.

Emmet county, I878, Cratty; Ames, I88o, Bessey; Grinnell, I877, Fones. 
50. C. Teretiuscula prairea (Dezu.) Britton. Illus. Flora, I, 344 ( I 896$)$.

C. teretiuscula var. ramosa Boott. Ill. Car., I45 (I867), not C'ramosa Schk. (1806).

Illus. Flora, l.c.; Bailey in Gray's Man., 6th ed., 615; MacMillan, Metas.

Minn. Val., I 13 ; Bruhin, Fl. Wis., 278 .

With the type, and probably more widely distributed. As it occurs with us it is usually coarser than the typical plant, the compound spike heavier. Not before reported from Iowa.

Estherville, Emmet county, June 25, I88I, Cratty; Grinnell, May, 1886, Norris; Story City, June 7, I897, Pammel \& Beyers; Granite, Lyon county, June, r897, Shimek; Armstrong, I897, Cratty.

51. C. Gravida Bailey. Typ. Car. 5 ( I889).

C. cephaloidea Auc. Am. in part, not of Dewey ( $18_{40}$ ).

C'. gravida var. laxifolia Bailey, Typ. Car. 6 (IS89).

Illus. Flora, I, 345, fig. 829; Bailey in Gray's Man., 6th ed., 6r 5; Arthur, Fl. Iowa, 33 (as C'. cephaloidea); MacMillan, Metas. Minn. Val., I 3 ; Webber, Fl. Neb., 98 .

Low ground, woods and prairies; common throughout, and quite variable. Most of the specimens found in the upper Mississippi Valley and referred to C. cephaloidea previous to I 890 belong here. In rich, moist soil in woods the plants are often 2 feet or more in height, the spikes very large and heavy, the foliage lax (var. laxifolia Bailey). In poorer soil or on the open prairies the plants are smaller and more strict in habit. C. alopecoidea Tuck. has been reported from this state, but the specimens so labelled in the I. A. C. herbarium are a lax form of the above species.

Emmet county, I878, and many later collections, Cratty; Iowa City, I893-4, Shimek; Ames, Hitchcock; Grinnell, I886, Norris; Scott and Muscatine counties, Barnes \& Miller; High Bridge, Dallas county, July 6, 1897 , and Grand River, June, I89o, Shimek; Spirit Lake, June 24, I88 I, Arthur; Marshalltown, I897, Pammel. 


\section{C. vulpinordea Michx. Fl. N. Am., il, I69 (I803).}

Illus. Flora, I, 345, fig. 830; Gray's Man., 6th ed, 615: Arthur, Fl. Iowa, 33;

Hitchcock, Pl. Ames, 525; MacMillan, Metas. Minn. Val., I13; Tracy, Fl. Mo., 95; Bessey, Cont. F1. Iowa, 123: Brendel, Fl. Peoriana, 62; Wheeler, Fl. Milwaukee Co., Wis., I87; Williams, Grass. and For. Pl. Daks., 42; Fink, Iowa Acad. Sci., IV, 105.

Very common in low, wet ground, the fruit a greenish brown when mature; quite variable in regard to size, usually growing in large, dense tufts, sometimes one or two feet in diameter. It is more common in ground that is occasionally flooded with water, but also occurs in quite dry soil along roadsides and in neglected places.

Johnson county, I894, Shimek; Emmet county, I878, and Spirit Laké, I896, Cratty; Fayette county, I895, Miss Ona M. Rounds; Greenfield, I892, Stewart; Ames and Iowa City, Hitchcock; Webster City, I89I, Pammel; Hamilton county, IS9I, Rolfs; Lucas county, Shepherd; Winneshiek county, July, I896, Fitzpatrick; Jasper county, May, I886, Norris; Johnson county, July, I897, a very slender form, Misses Finch \& Cavanagh; Muscatine Island, Louisa county, Aug. I, I897, Shimek \& Meyers; Fort Dodge, July 5, I897, Grand River, June, I89o, and Granite, Lyon county, June, I897, Shimek; Colo, July 6, I897, Vernon; Ledyard, Kossuth county, July 21, I897, Pammel; Missouri Valley, June 2I, I897, and Belmond and New Albin, I897, Pammel; Boone, I897, Steele; Le Claire, I897, Rolfs; Scott and Muscatine counties, Barnes \& Miller.

53. C. xanthocarpa Bicknell. Bull. Torr. Club, xx, 22 (1896). Pl. vir.

Illus. Flora, I, 345, fig. $\$_{3}$.

This species has not heretofore been reported west of Ohio. In general appearance it quite closely resembles the preceding but differs from it in having the culms much longer than the leaves, the bracts much shorter and inconspicuous, the larger ovate-elliptic perigynia a bright yellow. Our specimens have the perigynia wider than the figure in the Illus- 
trated Fiora. Prof. Bailey, to whom I sent a specimen, kindly verified my determination.

Peru, Madison county, July 2, I897, D. E. Hiolingsworth; Buffalo, Scott county, June 6, Ir.95, in dry sandy grass-land, growing in dense lufts, 3 to 4 feet high; also at Blue Grass in dry meadows, infrequent, Barnes \& Miller.

54. C. sartwelli Dew. Sill. Jour. xlin, 90 ( 1842$)$.

C. disticha Gray's Man., 5th ed., 574 (I867) not Hudson.

Illus. Flora I, 346, fig. 833; Gray's Man., 6th ed., 615; A rthur, Fl. Iowa, 33; Hitchcock, Pl. Ames, 525; MacMillan, Metas. Minn. Val., II3; Bessey, Cont. Fl. Iowa, I24; Brendel, Fl. Peoriana, 62; Webber, Fl. Neb., 98; Williams, Grass. and For. Pl. Daks., 43.

Low prairies, not common. The plant is usually diœcious with us, the fertile and sterile plants growing in separate patches. It seems to be very tenacious of life, several patches in the author's door-yard flowering and perfecting fruit every year in the hard packed soil along with knotweed (Polygonum aviculare L.). The plant varies from 6 to Io inches in height on higher ground, to 2 feet high in moister situations.

Emmet county, various collections, Cratty; station not given, but probably Ames, I87 I, Bessey; Noels and Blue Grass, Scott county, I894, Barnes \& Miller.

55. C. Rosea Schkuhr. Nacht. xv, I79 (I806).

Illus. Flora, I, 347, fig. 835; Bailey in Gray's Man., 6th ed., 6I6; Arthur,

Fl. Iowa, 33; MacMillan, Metas. Minn. Val., I 2 ; Bessey, Cont. Fl.

Iowa, I24; Tracy, Fl. Mo., 94; Brendel. Fl. Peoriana, 62; Bruhin, Fl.

Wis., 278; Webber, Fl. Neb., 98; Fink, Proc. Iowa Acad. Sci., Iv, 105.

Very common throughout in woods, and occasionally on low prairies. In the latter situation the plants grow in larger stools, are more slender and lighter colored, the spikes smaller. In deep, rich woods the plants are a darker green throughout.

Charles City, July, I875, Arthur; Iowa City, I889, Hitchcock; Emmet county, I896, Cratty; Johnson county, I895, Shimek; Fayette county, 1895, Fink; Shelby county, I895, and Decatur county, I897, Fitzpatrick; Grinnell, I885, Norris; Scott and Muscatine counties, Bames \& Miller; High 
Bridge, Dallas county, July 6, I897, Shimek; Marshalltown, May I, I897, No. 384, Pammel.

56. C. rosea radiata Dezu. Sill. Jour. x, 276 ( I 826 ).

Illus. Flora, I, 347; Gray's Man., 6th ed., 6r6; MacMillan, Metas. Minn. Val., I I2; Tracy, Fl. Mo., 94; 94; Upham, Fl. Minn., 49; Higley \& Raddin, Fl. Cook County, Ills., I36.

Rare, drier ground in woods. Almost capillary, spikes fewer, the 3 or 4 perigynia ascending. Not before reported from Iowa.

Johnson county, I895, Shimek; Ames, I875, Bessey; Iowa City, 1887, Hitchcock; Emmet county, Aug. 28, I897, Craity; Fort Dodge, July 5, I897, Shimek.

57. C. sparganioides Muhl. Willd. Sp. Pl. iv, 237 ( I805).

Illus. Flora, 1, 348, fig. 839; Gray's Man., 6th ed., 616; Arthur, Fl. Iowa, 33; Hitchcock, Pl. Ames, 525 ; Tracy, Fl. Mo., 525; Bessey, Cont. Fl. Iowa, I24; Brendel, Fl. Peoriana, 62; Wheeler, Fl. Milwaukee County, Wis., 187 .

Low ground, central, eastern and southern portions of the state; rather rare.

Charles City, June I, I875, Arthur; Ames, Hitchcock; Poweshiek county, July, I888, Norris; Scott and Muscatine counties, Barnes \& Miller; Decatur county, May. 24, I897, Fitzpatrick; Keokuk, June I, and High Bridge, Dallas county, July 5, I897, Shimek.

58. C. cephaloidea Dew. Rep. Pl. Mass., 262 ( 1840 ).

Illus. Flora, r, 348, fig. 840 ; Bailey in Gray's Man., 6th ed., 617.

Rare, usually in quite dry ground.

Swale near Le Claire, Scott county, i896, Barnes \& Miller. Determined by Prof. L. H. Bailey. This is the first time so far as known to me that the true plant has been detected within our limits. Nearly all the western plants heretofore referred to this species belong to C. gravida Bailey.

59. C. cephalophora Muhl. Willd. Sp. Pl. iv, 220 (1805).

Illus. Flora, I, 349, fig. 84I; Gray's Man., 6th ed., 617; Arthur, Fl. Iowa, 33: Hitchcock, Pl. Ames, 525: MacMillan, Metas. Minn. Val., III; Tracy, Fl. Mo., 93; Bessey, Cont. Fl. Iowa, I24; Brendel, Fl. Peoriana, 62 ; Hale, Add. Fl. Wis., 5 ; Fink, Proc. Iowa Acad. Sci., rv, ro6. 
Dry ground, common except in the northern portions of the state; a very pretty species, the plant a pale green, especially the small spikes.

Ames, June, I875, Arthur; Johnson county, I894, several collections, Shimek; Fayette county, I895, Skinner; Story county, Hitchcock; Muscatine, I89o, Reppert; Scott and Muscatine counties, Barnes \& Miller; Louisa county, Aug. I, I897, Shimek \& Meyers.

6o. C. Leavenworthil Dew. Am. Jour. Sci., 2nd ser., in, $246($ I 846$)$.

C. cephalophora var. ang gustifolia Boott. Ill. Car. 123 (1862).

Illus. Flora, I, 349, fig. 842; Gray's Man., 6th ed., 61 7.

Probably rare in the southwestern portion of the state. Not before reported from Iowa. This much resembles the preceding species, from which it is distinguished by its smaller size, very slender culms, and much narrower leaves, $1 / 2$ to $\mathrm{I} / 2$ lines wide. The heads and perigynia are smaller than those of $C$. cephalophora. So far as is known to the author, this species does not occur east of the Mississippi river. The range heretofore given is from Missouri and Arkansas to Texas.

Shelby county, May I I, I895, Fitzpatrick. My thanks are due Prof. Bailey for verifying my determination of this plant.

6I. C. sterilis Willd. Sp. Pl. iv, 208 (1805).

C. sterilis var. excelsior Bailey. Bull. Torr. Club, $\mathrm{xx}, 425$ (IS93).

Illus. Flora. I, 350, fig. 844; Gray's Man. 6th ed., 6I8; Arthur, Fl. Iowa, 33; Tracy, Fl. Mo., 95; Brendel, Fl. Peoriana, 62.

Moist soil, eastern portion of the state, rare.

Railroad track near Buffalo, Scott county, I895, Barnes \& Miller. 'I'his plant, the spikes large and approximate, differs from the type in having the perigynia much broader, I line long by $2 / 3$ line wide, and rounded or sometimes slightly cordate at the base. Prof. Bailey, who refers it to his var. excelsior, says, "very like C. atlantica." A similar form, but greener and 2 feet tall, was collected at Keokuk June I, I897, by Prof. Shimek, who also collected the typical form at High 
Bridge, Dallas county, July 6, I897. All specimens seen have the spikes contiguous.

62. C. interior Bailey. Bull. Torr. Club, xx, 426 (i893).

C. stcllulata var. scirpoides Boott. Ill. Car. (1858).

Illus. Flora, I, 350, fig. 849; Arthur, Fl. Iowa, 33; MacMillan, Metas. Minn.

Val., III; Rydberg, F1. Sand Hills, Neb., I85; Fink, Proc. Iowa Acad. Sci., IV, Io6.

Low ground, probably throughout the state.

Emmet county, I882, Cratty; Fayette county, I894, Fink; Scott county, I892, Barnes \& Miller; Grinnell, I885, Norris, and I886, Fohnson.

63. C. deweyana Schzuem. Ann. Lyc., N. Y., I, 65 ( 1864). Illus. Flora, I, 354, fig. 856; Gray's Man., 6th ed., 6rg; Arthur, Cont. Fl. Iowa, v; MacMillan, Metas. Minn. Val., IIO; Rydberg, Fl. Bl. Hills, S. D., 528 .

Dry ground in woods; a very pretty and delicate species, closely resembling $C$. bromoides Schkuhr, from which it is distinguished by its nerveless perigynia and oblong spikes. Dr. Arthur kindly loaned me his original specimen for examination.

Spirit Lake, June 21, I88I, Arthur.

Note.-C. bromoides Schkuhr, has been reported from Iowa, but I have been unable to find a specimen in any of the collections examined. It is reported by Prof. Tracy in his Flora of Missouri, p. 92, and by Bruhin in his Flora of Wisconsin, p. 278 .

64. C. muskingumensis Schwein. Ann Lyc., N. Y., I, 3 I 2 $(1825)$.

C. arida Schwein. and Torr. Ann. Lyc., N. Y., I, 3 I 2 (1825).

Illus. Flora, I, 355, fig. 68 I ; Gray's Man., 6th ed., 620; Arthur, Fl. Iowa, 33;

Hitchcock, Pl. Ames, 525; MacMillan, Metas. Minn. Val., Iog; Tracy,

Fl. Mo., 92; Brendel, Fl. Peoriana, 62; Bruhin, Fl. Wis., 279.

Woods, eastern and central, not infrequent; a large sedge, with crowded leaves on the sterile shoots, which with the long, narrow, cylindrical spikes give the plant an appearance strikingly distinct from any of our other carices.

Ames, Hitchcock; banks of Wapsipinicon river, Scott county, July 8, 1896, Barnes \& Miller; Jasper county, May, 
I886, Norris; woodlands along the Mississippi river, Clinton and Muscatine counties, Barnes \& Miller; Grinnell, I877, Fones; Ames, July r, I897, Stewart.

65. C. tribuloides Wahl. K. Acad. Handl. xxiv, 145 ( 1803$)$. Pl. viII.

C. lagopodoides Schkuhr, Nacht., 20 (1806).

Illus. Flora, I, 356, fig. 862; Gray's Man., 6th ed., 620; Arthur, Fl. Iowa, 34; MacMillan, Metas. Minn. Val, Io8; Bessey, Cont. Fl. Iowa, I24; Brendel, Fl. Peoriana, 62; Hale, Add. Fl. Wis., 5; Fink, Proc. Iowa Acad. Sci., IV, 106.

Low ground, usually near timber; probably throughout the state but not plentiful.

Ames and Grinnell, July 4, i 886, Fohnson; Eldridge, Scott county, June, July, I897, Barnes \& Miller; Johnson county, July, r897, Misses Finch \& Cavanagh; Keokuk, June I, I897, Shimek; Montrose, Sept., I883, Arthur.

66. C. Tribuloides bebbil (Olney) Bailey. Typ. Car., 55 ( I889).

C. bebbii Olney. Exsic. II, I2 (I870).

Illus. Flora, I, 356; Bailey in Gray's Man., 6th ed., 620; MacMillan, Metas. Minn. Val., I09; Brendel, Fl. Peoriana, 88; Webber, Fl. Neb., 98; Rydberg, Fl. Bl. Hills, S. D., 528; Fink, Proc. Iowa Acad. Sci., IV, Io6.

Very low ground, sloughs and margins of ponds and lakes; growing in dense tufts, the spikes clustered in a dense head. Not before reported from Iowa.

Emmet county, one mile east of Armstrong, July, I895, Cratty. Two forms occur; one with more slender culms, 6 to 12 inches high, the spikes about 3 lines long; the other 2 feet high, stouter, with the spikes a third larger. An imperfect specimen collected by Mr. Skinner in 1895 at Fayette probably belongs here.

67. C. tribuloides monillformis (Tuck.) Britton. Illus. Hlora, I, 356 ( 1896.$)$

C. scoparia var. moniliformis Tuck. Enum. Meth., I7 ( $8_{43}$ ).

C. tribuloides var. reducta Bailey. Proc. Am. Acad., xxin, i I8 (i886).

lllus. Flora, 1. c.; Gray's Man., 6th ed., 620; Fink, Proc. Iowa Acad. Sci., IV, 106. 
Southern and eastern. Not before reported from Iowa. The species and these two varieties, though widely distributed throughout the state, are probably rather rare.

Johnson county, I888, Miss Linder; Fayette county, I894, Fink; Spirit Lake, June 2I, I88r, Arthur.

68. C. scoparia Schkuhr. Riedgr. Nacht., 20 (I806).

Illus. Flora, I, 356. fig. 863; Bailey in Gray's Man., 6th ed., 620; Arthur, Fl.

Iowa, 33; MacMillan, Metas. Minn. Val., ıoS; Brendel, Fl. Peoriana, 62; Hale, Add. Fl. Wis., 5; Bot. Surv. Neb., III, I6; Fink, Proc. Iowa Acad. Sci., IV, 106.

Woods, probably throughout the state, but reported only from the eastern half. Very variable like the rest of the group.

Penn twp., Johnson county, I893, Cedar Rapids, r894, and Davenport, I895, Shimek; Charles City, July, I875, Arthur; Eldridge, Scott county, I897, Barnes \& Miller.

69. C. Cristatella Britton. Illus. Flora, i, 357 (I896).

C. cristata Schwein. Ann. Lyc. N. Y., I, 66 (IS24) not Clairv. (ISII).

C. straminea var. cristata Tuck. Enum. Meth., I8 (1843).

C. lagopodioides var. cristata Carey; Gray's Man., Ist ed., 545 ( $\mathrm{I}_{4} 8$ ).

Illus. Flora, 1. c., fig. 865; Gray's Man., 6th ed., 620; Arthur, Fl. Iowa, 34; Hitchcock, Pl. Ames, 525; MacMillan, Metas. Minn. Val., Io9; Tracy, Fl. Mo., 93; Brendel, Fl. Peoriana, 62; Bruhin, Fl. Wis., 278; Webber, App. Fl. Neb., 23.

Low ground along streams, margins of lakes, and edges of woods. Throughout but not plentiful.

Emmet county, rare, Aug., I89o, Cratty; Ames, Hitch-. cock; Scott and Mascatine counties, Barnes \& Miller; Decatur county, I897, Fitzpatrick; Mt. Pleasant, Oct. I, I887, Dr. Mitte.

70. C. Feenea Willd., Enum. 957 (i 809 ).

C. adusta Gray's Man., 5th ed., 580 ( IS67), not of Boott.

Illus. Flora, I, 357; fig. 867; Gray's Man., 6th ed., 62I; MacMillan, Metas. Minn. Val., I08; Brendel, Fl. Peoriana, 88.

Rare on moist prairies, central and eastern parts of the state.

Eldridge, Scott county, June, I897, Barnes \& Miller. Re- 
garding this collection Prof. Bailey writes. Mr. Barnes: "Very like C. silicea Olney." Ames, June 14, I897, (fide Boott); Belmond, I897, a doubtful form with the inner face smooth, Pammel.

7i. C. fenea perplexa Bailey; Mem. Torr. Club, i, 27 ( 1889 ).

Illus. Flora, I, 357; Bailey in Gray's Man., 6th ed., 62I.

Rare on prairies; not before reported from Iowa.

Buffalo, Scitt county, June, 1896, Barnes \& Miller. Cæspitose in habit, the culms $1 \frac{1 / 2}{2}$ to 3 feet high, spikes 3 to 6 , more aggregated larger and more truncate at the base than in type, the perigynia not strongly nerved on the outer face, and smooth or very obscurely nerved on the inner. Spirit Lake, June 24, 1881, Arthur. This latter is the C. adusta of Arthur's catalogue. It seems to be identical with the Scott county plant which was determined by Prof. Bailey.

72. C. straminea Willd. Schkuhr. Riedgr. 49 (180r).

Illus. F'lora, 1, 3.58, fig. 86\%; Bailey in Gray's Man., 6th ed., 62 I ; A rthur, Cont.

Fl. lowa, iı ; MacMillan, Metas. Minu. Val., ıo6; Tracy, Fl. Mo., 94;

Brende!, Fl. Peoriana, 62; Rydberg, Fl. Sand Hills Neb., ${ }_{85}$; Fink, Proc. Iowa Acad. Sci., Iv, Io6.

Woods and prairies; the typical plant seems to be rather scarce. This and the related species and varieties run together inextricably, and form a most perplexing group.

Fayette county, 1895, Fink; Scott county, June, I897, Barnes \& Miller; Emmet county, a form common on dry prairies with stiffer culms, to to 20 inches high, and larger spikes and perigynia, clo ely approaching C. festucacea Willd., Cratty; Decatur county, July, I897, Fitzpatrick; Granite, Lyon county, June, I897, Shimek; Spirit Lake, June 4, I88I, Arthur.

73. C. straminea mirabilis (Dez.) Tuck. Enum. Meth., I8 ( I 843$)$.

C. mirabilis Dew. Sill. Jour, $\mathrm{xxx}, 63(1836)$.

Illus. Flora, I, 358; Bailey in Gray's Man., 6th ed., 62 I: Macdillan, Metas.

Minn. Val., I07; Upham, Supl. Fl. Minn., 49; Vebber, Fl. Neb., 98. 
Rare in low ground; central portion of the state.

Ames, June I, 1877, Arthur, and another colleciion, Fohnson; Poweshiek county, July 4, I886, Fohnson; Charles City, July, i875, Arthur.

74. C. Tenera Dezu. Am. Jour. Sci., vili, 97 (I824).

C. straminea var. aperta Boott, Ill. Car. I 20 ( IS62).

C. straminea var. tenera Bailey, Bot. Gaz. $\mathrm{x}, 3 \mathrm{~S}_{\mathrm{I}}$ (1885).

Illus. Flora, I., 358. fig. 87o; Gray's Man., 6th ed., 622; Bruhin, Zwei. Nach.

Fl. Wis., 643; Williams, Grass and For. Pl. Daks., 43; Higley \& Raddin,

Fl. Cook Co., Ills., i38.

Rare in low ground.

Spirit Lake, June 2 I, I88I, Arthur; Emmet connty, „S84, Cratty; Johnson county, May 28, I894, Shimek; Ames, Carver; Jasper county, I886, Norris.

Part of the above are not typical, but seem best referred here. The perigynia are broader than would appear from the figure in the Iilustrated Flora. In the Emmet and Johnson county plants the spikes are 3 to 5 , light colored, the upper two usually contiguous. Dr. Arthur cullected a large form at Ames which appears to connect this with the next.

75. C. festucacea Willd. Sp. Pl., iv., 242 (1825).

C. straminea var. brevior Dew. Sill. Jour. XI., I 58 . ( I 826 ).

Illus. Flora, I., 359, fig. 87 I Gray's Man., 6th ed., 622; Arthur, Fl. Iowa, 34, and Cont. Fl. Iowa, v.; MacMillan, Metas. Minn. Val., Io6; Bruhin, Zwei, Nacht, Fl. Wis, 643; Webber, App. Fl. Neb., 23; Williams, Grass \& For. Pl. Daks., 43; Higley. \& Raddin, Fl. Cook Co., Ills., I38.

Common on prairies everywhere throughout the state; very variable.

Chrrles City, June 29, I875, Arthur; Lyon county, I896, and Johnson counny, I894-5, Shimek; Iowa Clty, I889, Hitchcock; Hamilton county, I89 I, Rolfs; Lucas county, Shepherd; Emmet county, i896, Cratty; Ames, i897, Arthur; Eldridge, June, i897, Barnes \& Miller; Spirit Lake, i881, Arthur; Decatur county, Aug., I897, Fitzpatrick; Lyon county, I897, and Keokuk, June I, 1897, Shimek; Charles City, June, I874, Arthur; Des Moines, May 17, г897, L. H. \& Emma Pam- 
mel; Fort Dodge, July 5, I 897 , Shimek; Missouri Valley, June 2 I, I897, a form approaching the next species, Pammel.

A form collected by Prof. Hitchcock at Amés is labeled "var. brevior, approaching var. alata" by Prof. L. H. Bailey. Similar forms were collected at Charles City by Dr. Arthur, and at Eldridge, Scott county, June, I897, by Messrs. Barnes \& Miller. This latter plant is the C. straminea var. fermuginea Bailey, Bull. Torr. Club, xx., 42 I (I893).

76. C. alata Torr. Ann. Lyc. N. Y., III., 396 (i826).

C. straminea var. alata Bailey. Cat. Car., ( $\left(\mathrm{IS}_{4}\right)$.

Illus. Flora, I., 359, fig. 872; Gray's Man., 6th ed. 622; Hitchcock, Pl. Ames, 525; Higley \& Raddin, Fl. Cook Co., Ills., I3 8 .

Low ground, rare within our limits: The specimens have the perigynia slightly narrower, the beak a little longer than in the eastern plant.

Ames, Hitchcock; a specimen in the I. A. C. herbarium labelled "Iowa, June 23, I87 I, Bessey;" Grinnell, June, I886, an intermediate form which I refer here, Norris.

77. C. Bicknelli Britton. Illus. Flora, I., 360, fig. 874 $(1896)$.

C. straminea var. crawii Boott, Ill. Car. I2 I (I862), not C. crawii Dew. ( $\left.\mathrm{I} \mathrm{S}_{4} 6\right)$, which is an accepted species.

Illus. Flora, 1. c.; Bailey in Bull. Torr. Bot. Club., xx., 42I; Arthur, Flora Iowa, 34, no. SSI ; Rydberg, Fl. Bl. Hills, S. D., 527.

Rare and uncharacteristic with us. The broadly winged perigynia shell off very easily when mature. Usually but few plants are found in a place, and those very loosely tufted.

Emmet county, I878, Cratty; Johnson county, I894, Shimek, and Ames, June I6, I877, Arthur. The two latter I refer here with some hesitation. Keokuk, June I, I897, a form with the beak one-half the length of the body of the perigynium, Shimek.

78. C. sychnocephala C'arey. Sill. Jour., ser. 2, IV., 24 ( $\mathrm{IS}_{47}$ ). Pl. Ix.

Illus. Flora, r., 360, fig. 875; Gray's Man., 6th ed., 622; MacMillan, Metas,

Minn. Val., I06; Bruhin, $Z$ wei, Nach. Fl. Wis., 643; Beal \& Wheeler, Fl. Mich., I 57 . 
Rare in sloughs and on the margins of ponds and lakes. Not before reported from Iowa. This sedge usually grows in dense tufts, erect, 6 to 18 inches high, but numerous clumps with prostrate culms 2 feet long were found growing with the type one mile east of Armstrong, July, 1896 . This plant seems to thrive best on land which is flooded during the spring.

Emmet county, July I2, I89 I, Cratty; Spirit Lake, July 30, I896, Cratty \& Shimek.

\section{APPENDIX.}

Since the manuscript for this paper was placed in the hands of the printer considerable material, illustrating geographical distribution, has been received which it is desirable to include. Owing to a misunderstanding regarding the scope of the paper, a considerable amount of material belonging to the genera preceding Carex, was not placed in my hands in time to insert the data in the proper place in the body of the paper. The greater portion of the material here used was collected by Prof. Shimek of the Iowa State University, and by Prof. C. R. Ball of the State College of Agriculture, to both of whom I am deeply indebted for the generous assistance they have so freely given me.

It has been found necessary to withhold a small amount of material for further study and observation.

$$
\text { P. } 3 \text { I } 8 \text {. }
$$

Cyperus rivularis Kunth; Forest City, I895, and Johnson county, July, r895, Shimek.

$$
\text { P. 3I9. }
$$

C. inflexus Muhl.; Johnson county, Sept. I894, Shimek.

$$
\text { P. } 3 \text { I9. }
$$

C. schweinitzii Torr.; Muscatine, Oct., I 896, Clear Lake, Cerro Gordo county, July, I896, and Johnson county, I894, Shimek; Jackson county, I895, P. Bartsch; Winneshiek county, 
H. Goddard; Vinton, June, I898, Ball; Muscatine, Aug., I897, a peculiar form closely approaching $C$. filiculmis in general appearance.

$$
\text { P. } 3 \text { I9. }
$$

C. acuminatus Torr. \& Hook.; Sioux City, rritchcock.

$$
\text { P. } 320 \text {. }
$$

C. esculentus L.; Iowa City, Hitchcock; Clayton county, June, I895, and Des Moines county, Aug., I 895, Paul Bartsch; Hamburg, I898, Shimek; Ames, July, ı897, Ball; Lebanon, July, I8g8, Ball \& Sample.

$$
\text { P. } 32 \mathrm{I} \text {. }
$$

C. speciosus L.; Johnson connty, ז889, Miss Linder; Lyon county, Aug., I896, Shimek; Van Buren county, July, I 898 , Ball.

$$
\text { P. } 32 \text { I. }
$$

C. strigosus L.; Forest City, July, I896, Shimek; Des Moines county, Paul Bartsch.

$$
\text { P. } 322 \text {. }
$$

C. strigosus compositus Britton; sandy river bottoms, Johnson county, Sept., I894, Shimek.

$$
\text { P. } 322 \text {. }
$$

C. filiculmis Vahl.; Keokuk, July, I895, and Johnson county, July, I895, Shimek; Winneshiek county, June, I895, H. Goddard.

P. 324 .

Eleocharis ovata (Roth.) R. \& S.; Lyon county, June, I897, Shimek.

$$
\text { P. } 324 \text {. }
$$

E. palustris (L.) R. \& S.; Spirit Lake, Aug.; I896, and Davenport, I 895 , Shimek; Pottawattamie county, June 3, I $897, \mathcal{F}$. E. Cameron.

$$
\text { P. } 325 \text {. }
$$

E.acicularis (L.) R. \& S.; Lake Edwards, Hancock county, I 895, Johnson county, I 895, Forest City, July, I896, Cedar Rapids, June, I894, and Rock Rapids, Aug., I896, Shimek. 
P. 326.

E. temis (Willd.) Schultes; Iowa City, Macbride; Lyon county, June, I897, Shimek.

$$
\text { P. } 328 .
$$

Scirpus americanus Pers.; Ames, June, I897, Meeker \& Ball. P. 329 .

Scirpus lacustris L.; Clear Lake and Hancock county, July, I896, Shimek; Mt. Pleasant, 7. H. Mills; Pottawattamie county, June, I897, F. E. Cameron; Albin, July ı, I898, Ball.

$$
\text { P. } 329 .
$$

S. fluviatilis (Torr.) Gray; Hancock county, July I7, I896, Shimek; Ames, June, I898, Ball \& Sample.

$$
\text { P. } 330 \text {. }
$$

S. atrovirens Muhl.; Mt. Pleasant, July 7, i 898, Muscatine, July 4, I898, and Vinton, June, I898, Ball; Rock Rapids, I896, Forest City, July I7, I896, Mason City, July, I896, Iowa City, June, I894, Keokuk, July, I895, and Grand River, June, I89o, Shimek; Mt. Pleasant, F. H. Mills; Winneshiek county; June I3, I896, H. Goddard.

$$
\text { P. } 33 \text {. }
$$

S. lineatus Mich.; Minerva, June, I898, and Van Buren county, Ball; Wilsonville, July 7, ı895, H. C. Taylor; Cedar Rapids, Hitchcock.

$$
\text { P. } 33^{2} \text {. }
$$

Hemicarpha micrantha (Vahl.) Britton; sandy river bottoms, Johnson county, Sept., I894, Shimek.

$$
\text { P. 333. }
$$

Scleria triglomerata Mich; Monroe county, July I3, I898, Ball.

$$
\text { P. } 336 .
$$

Carex Iupulina L.; Keokuk, July, I895, Shimek; Dubuque, July I7, I895, Paul Bartsch.

$$
\text { P. } 336 \text {. }
$$

C. monile Tuck.; Story City, June 4, I898, Ball. 
P. 338 .

C. comosa Boott; Muscatine, Sept., I892, Shimek. A peculiar form with the two upper spikes nearly sessile.

P. 339 .

C. typhinoides Schwein.; Dubuque, July i7, i895. Paul Bartsch.

$$
\text { P. 339. }
$$

C. trichocarpa, Muhl.; Vinton, June 29, i898, Ball.

P. 340 .

C. shortiana Dew.; Muscatine, July 4, I898, Ball; Keokuk, July 5, i 895 , Shimek.

$$
\text { P. 34I. }
$$

C. lanuginosa Mich.; Story City, June, I 898, Ball \& Sample.

$$
\text { P. } 343 \text {. }
$$

C. dazisii Schwein. \& Torr.; Ames, June, r898, Ball.

$$
\text { P. } 344 \text {. }
$$

C. longirostris Torr.; Mason City, July 7, I896, Shimek.

$$
\text { P. 344. }
$$

C. grisea Wahl.; Garwin, Juné 29, I898, and Ames, June 20, I898, Ball.

$$
\text { P. } 346 \text {. }
$$

C. hitchcockiana Dew.; Keokuk, Jaly 5, i895, and Johnson county, May, I894. Shimek. The latter plant has the leaves as well as the sheaths pubescent, the perigynia scabrous. A specimen of this from the same locality, collected later in the season would be interesting.

\section{P. 347 .}

C. laxiffora blanda (Dew.) Boott; Forest City, July i 7, I\&96, Shimek.

$$
\text { P. } 347 \text {. }
$$

C. albursinu Sheldon; Jackson county, Aug., I894, Shimek.

$$
\text { P. } 349 \text {. }
$$

C. pennsylianica Lam.; Ames, i898, Ball.

$$
\text { P. } 352 \text {. }
$$

C. stipata Muhl.; Cedar Rapids, May r 5, r 898, Shimek. 


$$
\text { P. } 353 \text {. }
$$

C. grazida Bailey; Lebanon, July i I, i 898, Ball.

$$
\text { P. } 354 \text {. }
$$

C. ílpinoidea Mich.; Ames, June 20, I898, Minerva, June, I 898, Muscatine, July, 1898 , and Vinton, June, I898, Ball; Davenport, Forest City, July I8, I896, Rock Rapids, Lyon county, Aug. 5, I898, and Mason City, July 6, 1896, Shimek.

$$
\text { P. } 354 \text {. }
$$

C. xanthocarpa Bicknell. What I take to be this species was collected by Prof. Shimek at Cedar Rapids, June 7, I894. The lower branch is one in. long; otherwise much like the type.

\section{P. 355 .}

C. rosea Schk.; Cedar Rapids, May I 5, I 896, Shimek; Garwin, June 29, 1898 , Ball.

$$
\text { P. } 356 \text {. }
$$

C. rosea radiuta Dew ; Lebanon, July I I, I 898, Bull \& Sample; Ames, June, I898, nearly this, Ball \& Sample.

$$
\text { P. } 356 \text {. }
$$

C. sparganioides Muhl.; Iowa City, I 894, Shimek; Ames, June 3, I 898, Bull.

$$
\text { P. } 356 \text {. }
$$

: C. cephalophora Muhl.; Ames, June, I898, Ball \& Sample.

$$
\text { P. } 358 \text {. }
$$

C. muskingumensis Schwein.; Muscatine, Sept, I896, Shimek.

$$
\text { P. 359. }
$$

C. tribuloides Wahl.; Ames, June, I898, Ball. Prof. Shimek. collected near Mason City a form intermediate between this and C. tribuloides bebbii.

$$
\text { P. } 359 \text {. }
$$

C. tribuloides moniliformis (Tuck.) Britton; Ames, June 20, i $89 \mathrm{~S}$, Ball.

$$
\text { P. } 360 \text {. }
$$

C. sroparia Schk.; Vinton, June 29, I898, Ball. 


$$
\text { P. } 360 \text {. }
$$

C. cristatella Britton; Vinton, June 29, I898, Ball.

$$
\text { P. } 360 \text {. }
$$

C. adusta Boott. Prof. Shimek collected at Rock Rapids, Lyon county, Aug., I896, what appears to be this species. Further observation is needed.

C. fonea Willd on p. 360.

$$
\text { P. } 362 \text {. }
$$

C. tenera Dew.; Forest City, July I8, I896, nearly this, Shimek.

$$
\text { P. } 362 \text {. }
$$

C.festucacea Willd.; Cedar Rapids, May I 5, I896, and Rock Rapids, Augr., I896, Shimek; Monroe county, July, I898, Ball.

$$
\text { P. } 363 \text {. }
$$

C. bicknellii Britton; Ames, June 2 I, I898, Ball.

\section{SUMMARY.}

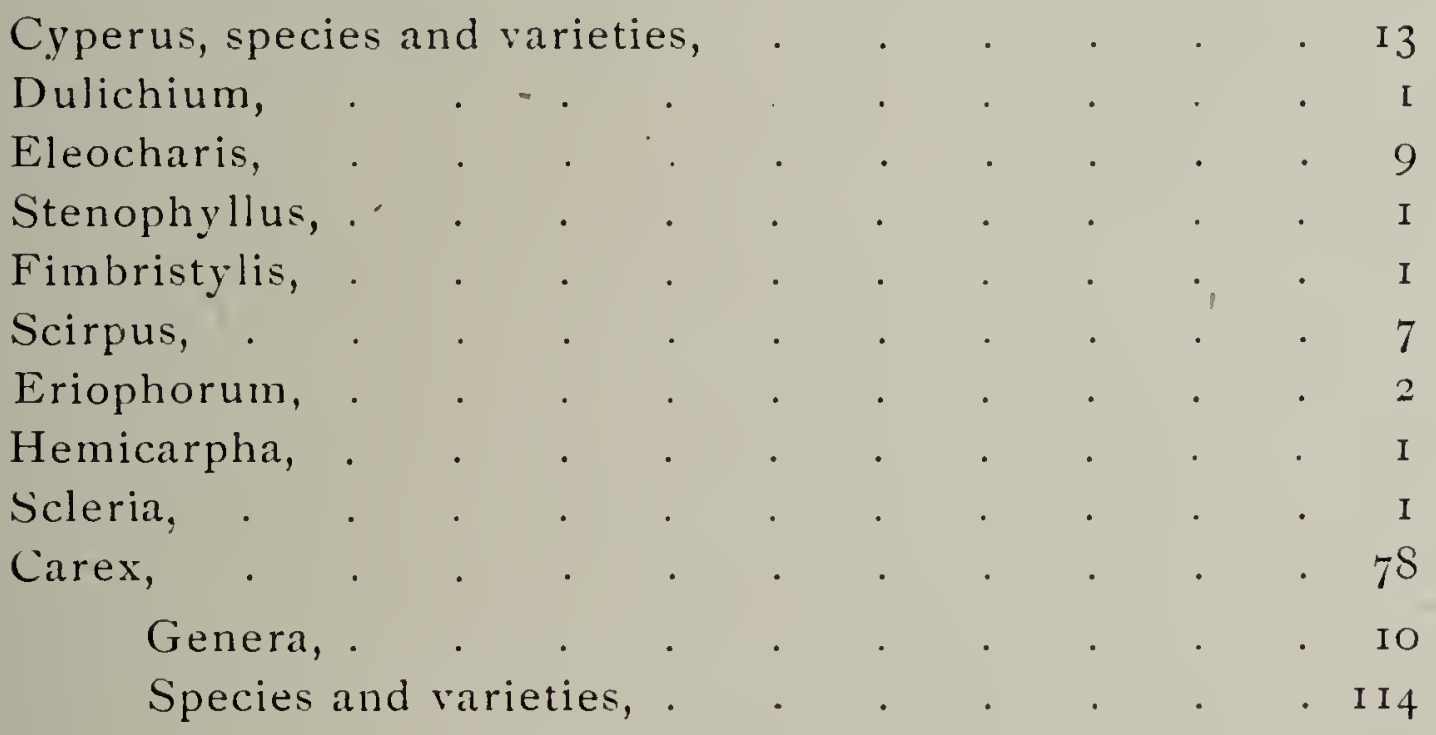


Table showing the sedge flora of Iowa and the neighboring states from which each species and variety has been reported:

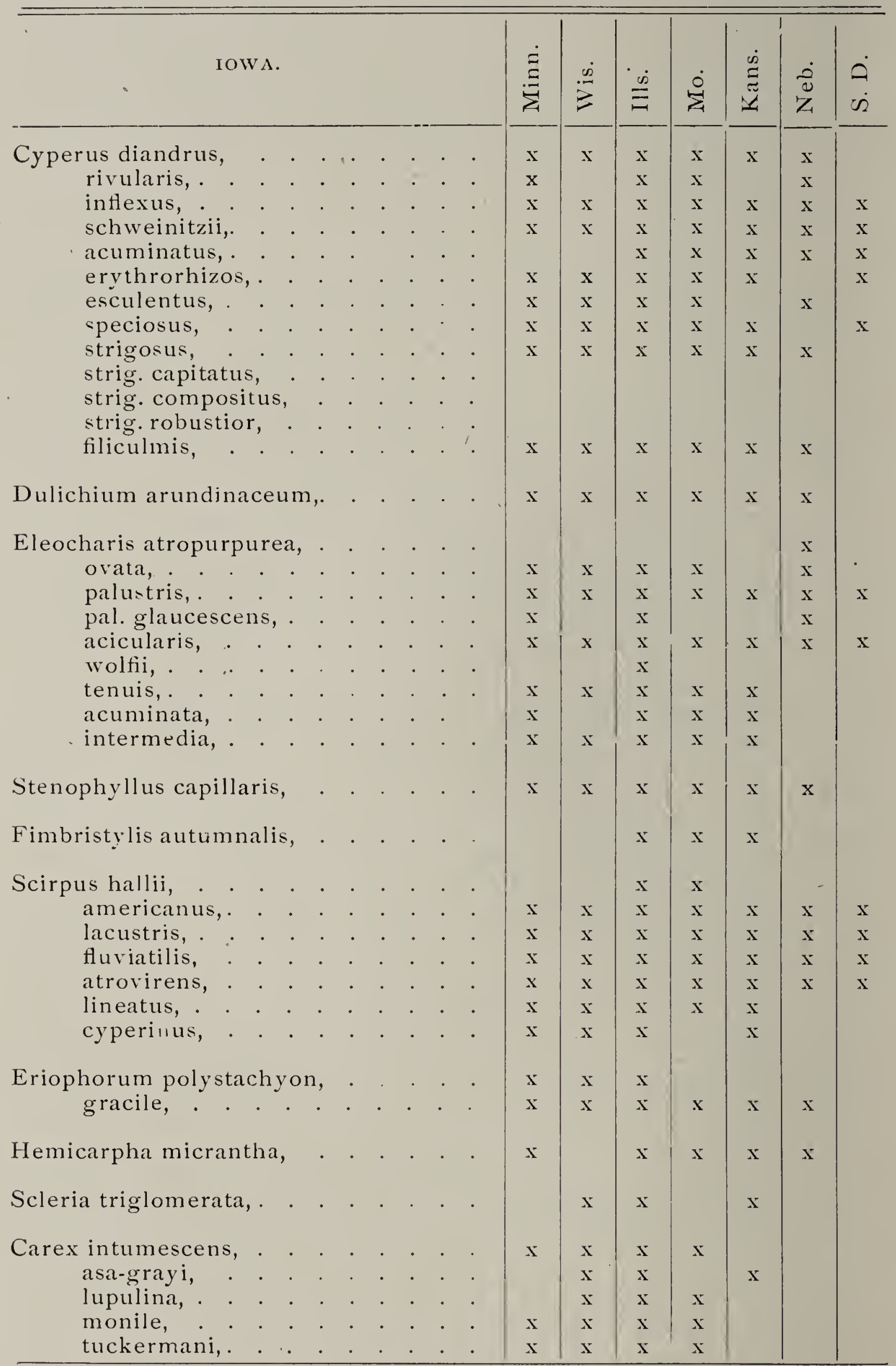




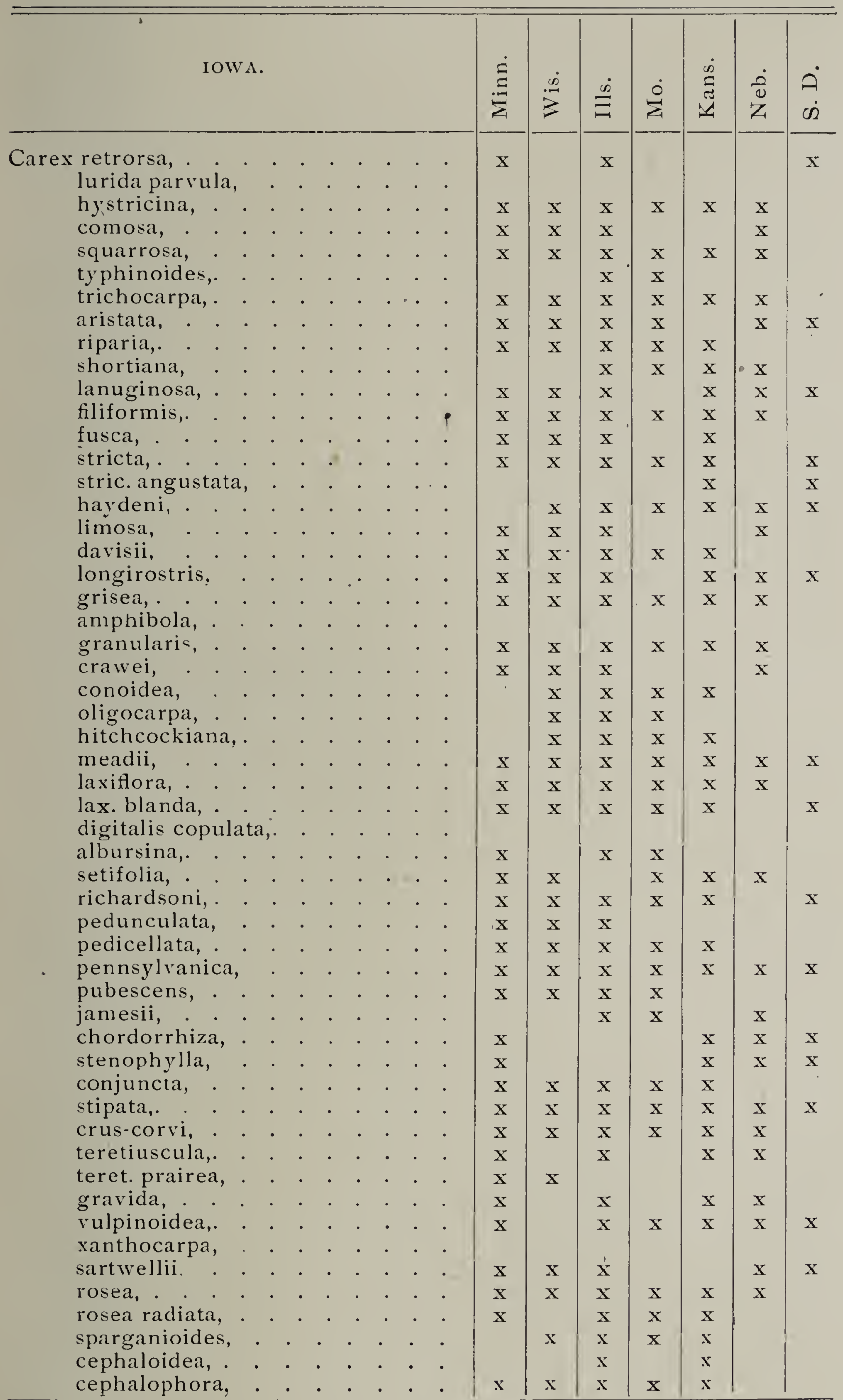




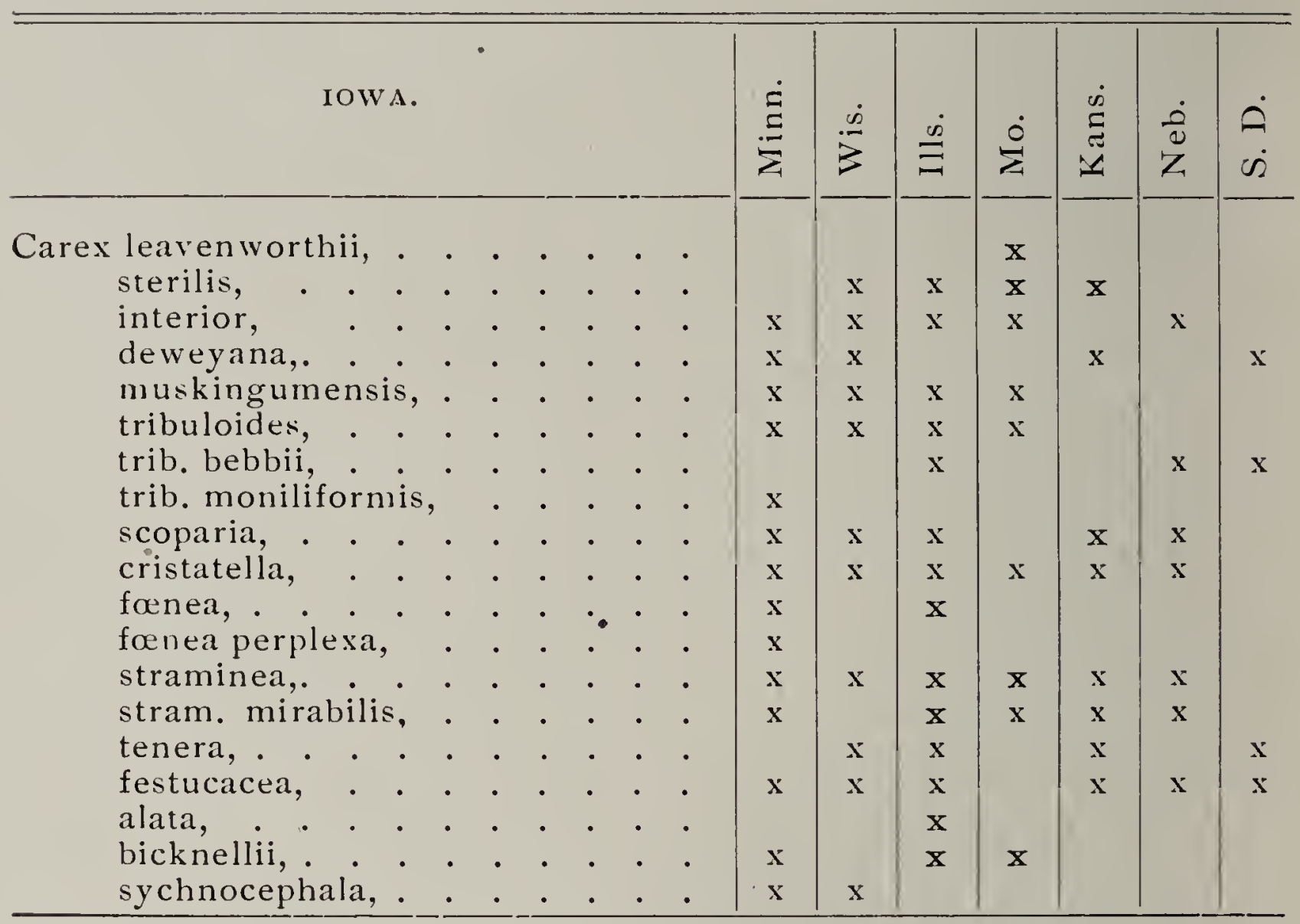

From the above table the following statements are deduced:

Species common to the whole group . . . . . Io Iowa species reported from Minnesota. . . . . 89

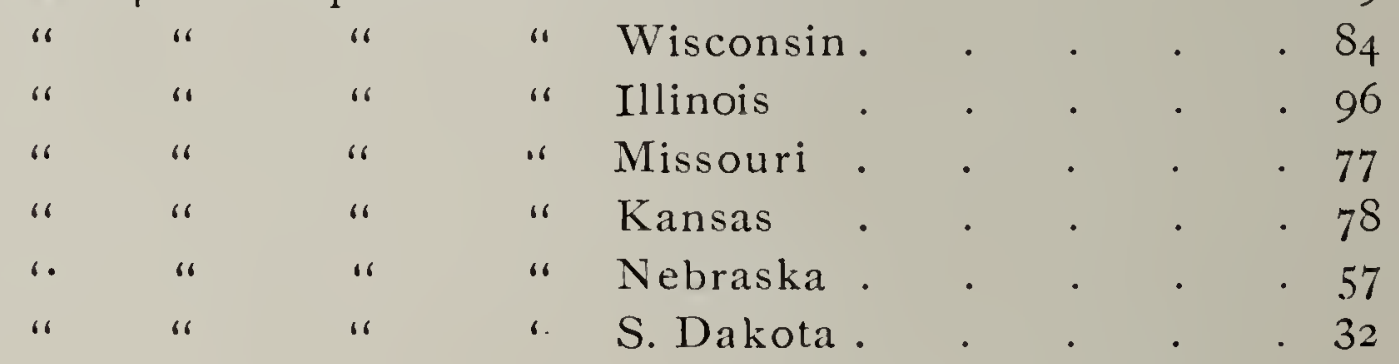

Per cent. of Iowa sedges in Minnesota. . . . . 78

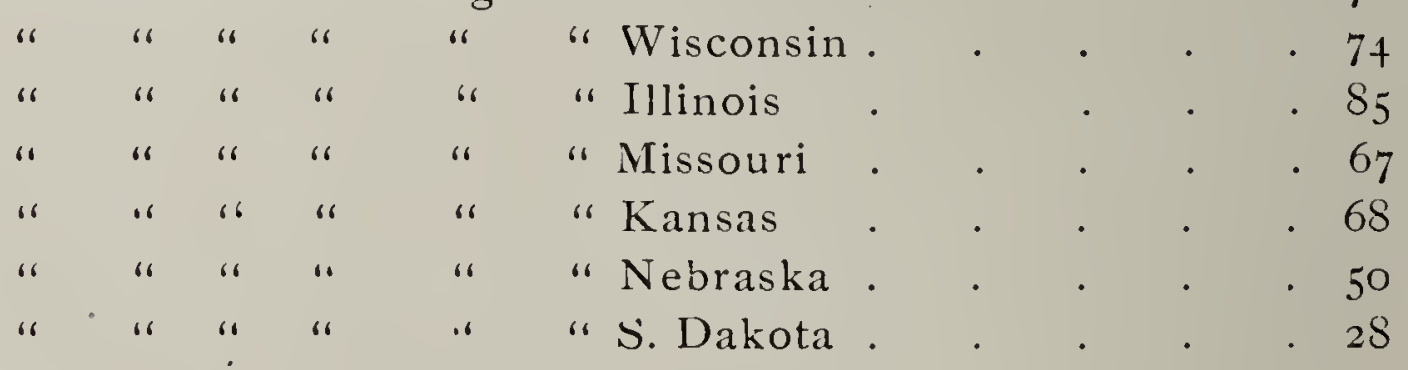




\section{INDEX.}

[SYNONYMS IN ITALICS.]

CAREX adusta Gray. . 333, 360, 369 alata 7 orr. . . . . 363 albursina Sheldon. . 347,367 amphibola Steud. . . . 344 aperta Boott . . . . 342 aquatilis Wahl. . . . . 343 arida Schwein. \& Torr. $35^{\circ}$ aristata $\mathrm{R} . \mathrm{Br} . \quad \cdot \quad \cdot 34 \mathrm{O}$ asa-grayi Bailey. . . . 335 bicknellii Britton . 363,369 blanda Dew. . . . . . 347 bromoides Schkukr. . $35^{8}$ buxbaumii Wahl. . . $34 \mathrm{I}$ cephaloidea Dew. . . . 356 cephalophora Muhl. $\quad 356,368$ cephalophora angustifolic

Boott . . . . 357 chordorrhiza Limn.f. $\quad 350$ communis Bailey. . . . 349 comosa Boott . . 338, 367 conjuncta Boott . . . . $35 \mathrm{I}$ conoidea Schkulur. . . 345 crawei Deurey. . . . 345 cristata Schwein. . . . 360 cristatella Britton . $\quad 360,369$ crus-corvi Shuttlew. . . $35^{2}$ davisii Schw. \& Torr. 343,367 deweyana Schwein. . $35^{8}$ digitalis copulata Bailey. 347 distieha Huds. . . . . 355 eburnea Boott . . . 348 festucacea Willd. . 362, 369 flliformis $L$. . . . . . $34 \mathrm{I}$ fil. latifnlia Bøckl. . . . 34 I fil. lanuginosa Michx. . . 34 I fœnea Willd. . . . . 360
Carex fonea perplexa Bailey 361 fusca $A l l$. . . . . . . 341 granularis Muhl. . . 344 gravida Bailey . $\quad 353,368$ grav. laxifoliu Bailey . . 353 grayi Carey. . . . . 335 grisea Wahl. . . . 344, 367 gris. angustifolic Boott . 344 haydeni Dew. . . . . $34^{2}$ hitchcockiana Dezw. $\quad 346,367$ houghtonii Torr. . . . $34^{\mathrm{I}}$ hystricina Muhl. . . $33^{S}$ interior Bailey . . . $35^{8}$ intumescens Rudge. . 335 jamesii Schwein. . . 350 lagopodioides Schkuhr. $\quad 359$ lanuginosa Michx. . 341,367 laxiflora Lam. . . . 346 laxiflora blanda Boott. 347,367 lax. latifolia Boott . . . 347 lax. striatula Boott . . . 347 leavenworthii Dew. . 357 limosa L. . . . . . 343 longirostris Torr. . $\quad 344,367$ lupulina $M$ Mull. . . 336, 366 lurida parvula (Paine)

Bailey . . . . . 337

meadii Dew. . . . . . 346 meadii bebbii (Olnel)

Arthur . . . . 346 mirabilis Dew. . . . $36 \mathbf{I}$ monile Tuck. . . . 336,366 muskingumensis $S c h .358,368$ oligocarpa Schkuhr. . . 345 pedicellata (Dew.) Britton 349 pedunculata $M$ uhl. . 349 
CAREx pennsylranica Lam. 349, 367 pseudo-cyperus L. . 338 pseudo-cyp.comosa Boott . 338 pseudo-cyp. americana

Hoch. . . . . 338 pubescens Muhl. . . 350 retrorsa Schwein. . . 337 richardsoni R. Br. . 348 riparia $W$. Curtis . . 349 rosea Schkuhr. . . 355,368 rosea radiata Dew. 356,368 sartwellii Dew. . • 355 scoparia Schkuhr. . $\quad 360,368$ setifolia (Dev.) Britton . $34 \mathrm{~S}$ shortiana Dew. . . 340, 367 sparganioides $M$ L squarrosa $L$. . . . 338 squarrosa typhnoides

Dewey . • . • • 339 stellulata scirpoides Boott 358 stenophylla Wahl. . . 35I sterilis Willd. . . . . 35 . steudellii Kunth. . . 350 stipata $M n h l . . \quad$. 352,367 straminea Willd. . . . $3^{61}$ stram. mirabilis (Dew.)

Tuck. . . . . . $3^{6 \mathrm{I}}$ stram. alata Bailey. • . 363 stram. aperta Boott . . 362 stram. brevior Dew. . . 362 stram. crawei Boott . . 363 stram. tenera Bailey. . . 362 stricta Lam. . . . . 342 stricta angustata Bailey. $3 t^{2}$ stricta decora Bailey. . 342 sychnocephala Carey. $\quad 363$ tenera Deru. . . . 362, 369 teretiuscula Good. . $\quad 352$ ter. prairea (Dew.) Brit-

ton. . . . . . . 353 ter. ramosa Boott . . . 353 tetanica meadii Bailey. 346 tribuloides Wahl. . 359,368 trib. bebbii (Olney) Bai-

ley. . . . . . . 359 trib. moniliformis (Tuck.)

Brilton . . . $359,3^{68}$
Carex trib. reducta Bailey - 359 trichocarpa $M u h l . \quad$. $3.39,367$ trach. aristata ( $\mathrm{R} . \mathrm{Br}$.)

Bailey • . . . 340 trich. dewey Bailey. • . 339 trich. imberbis Gray . . 339 trich.lceviconica (Dew.)

Hitch. . . . . 339 tuckermani Dew. . . . 337 typhinoides Schrvein. 339,367 vulpinoidea Mich. $\quad 354,368$ xanthocarpa Bicknell. 354,368 Cladium mariscoides ( $M / u h l$.) Torr. . . . . . 333

Cyperus. . . . . . . . 318 acuminatus $T$.d $H . \quad 319,365$ aristatus Bœckl. . . 319 diandrus Torr. . . . 318 dian. castaneus Torr. - $3 \mathrm{IS}$ erythrorhizos $M$ Mhl. . 320 esculentus $L$. . . $\quad 320,365$ filiculnis Vahi. . 322,365 inflexus $M u h l .: \quad 319,364$ michauxianus Gray. • . $32 \mathrm{I}$ phymatodes Muhl. • . 320 rivularis Kunth. . $\quad 318,364$ schweinitzii Torr. 319,364 speciosus $L$. . . $\quad 321,365$ strigosus $L$. . . $\quad 321,365$ strig. capitatus $B$ acckl. $\quad 322$ strig. compositus Brit. 322,365 strig. robustior $K u n t h . \quad 3^{22}$

Dulichilu. . . . . . . 323 arundinaceum $\left(L_{.}\right)$

Britt. . . . . . 323 spathaceum Pers. . . . 323

Eleocharis. . • • . • 323 acicularis $(L)$.$R \& S .325,365$ atropurpurea (Retz.)

Kunth. . . . . . 324 acuminata (Muhl.) Nees. 326 compressa Sulliv. • . 326 engelmanni Steud. • . 324 intermedia $(M I h h l$.

Schultes. . . . . 326 ovata (Roth.) R. \& $S .324,365$ palustris (L.) R. \& $S .324,365$ 
Eleocharis pal. glaucescens

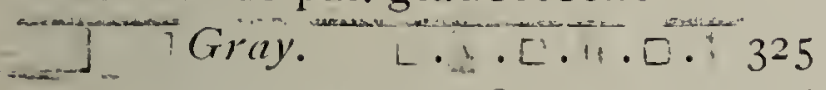
tenuis (Willd.) Schult. 326, 366 wolfii Gray'. . . . 326

ERIOPHOR UM.

cyperinum 5

gracile Koch. . . . . 332

lineatum Benth. \& Hook. 330 polystachyon $L$. . . 33 I

HEMICARPHA. . . . . . 332 micrantha (Vahl.) Brit.332, 366 subsquarrosa Nees. . . 335

Fimbristylis. . . . . . $\quad 327$ autumnalis (L.) R. de S. 327 capillaris A. Gray . $\quad 327$ castanea (Wich.) T'ahl. . $32 \mathrm{~S}$

RHYNCHOSPORA.

332 alba (L.) Vahl. . . . 332 capillacea (Mich.) Vahl. . 332
Scirpus. • . . . . . $\quad 328$

americanus Pers. . 32S, 366 atrovirens $M$ Iull. . $\quad 330,366$ cyperinus (L.) Kunth. . 330 fluviatilis (Torr.) Gray.329, 366 hallii Gray' • . . . . 328 lacustris $L$. . . 326,366 lineatus Michx. . . 330, 366 pungens Vahl. . . . . 328 supinus hallii Gray. . . $32 \mathrm{~S}$ tenuis (IVilld.) • . . . 326 triangularis (Pers.) Mac-

Millan.. . . . 328 validus Vabl. . . . 329

Scleria. . . . . . . . 333 triglomerata Michx. 333,366 Steñophyllus. • • • • 327 capillaris (L.) Britton. . 327 


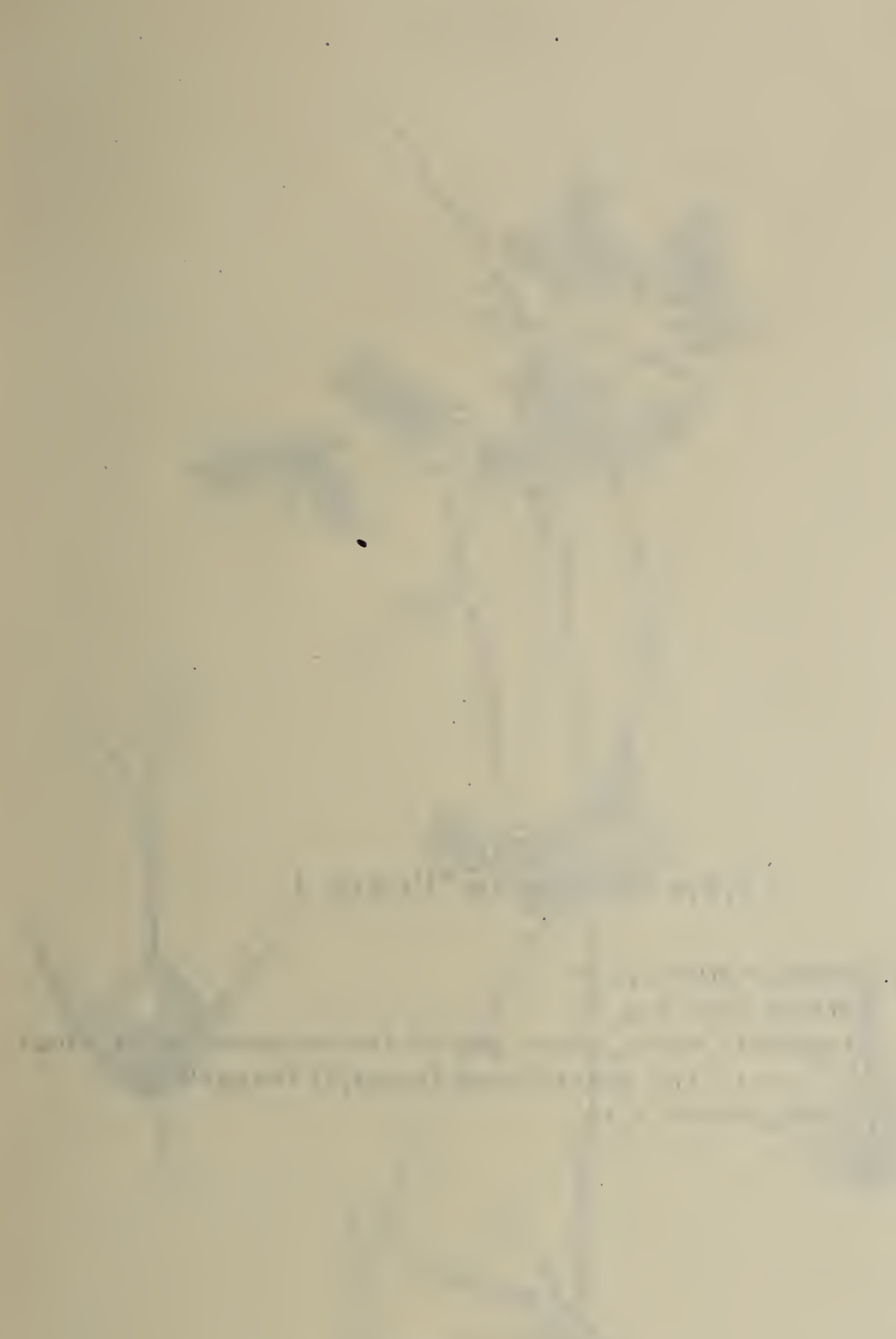


\section{Explanation of Plate I.}

Cyperus erythrorhizos Muhl., p. 320.

Whole plant $\times \frac{1}{2}$.

Immature akene, with a pair of the detached rachis wings. $X$ i2. (The mature akene is sharply triangular.)

A single scale $X$ i 2 . 
PLATE 1.

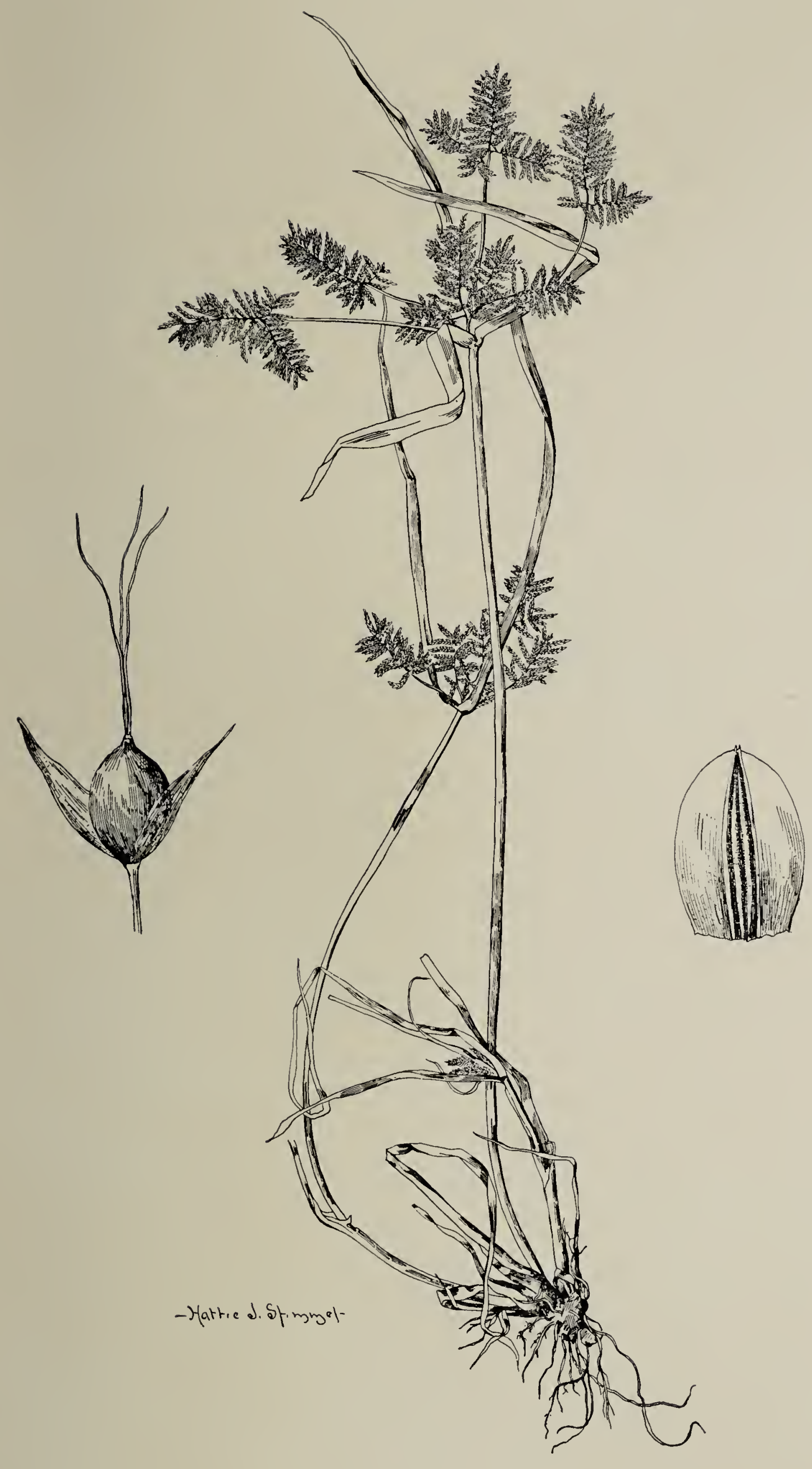




\section{LIBRARY \\ OF THE \\ UNIVERSITY OE ILLNDIS}



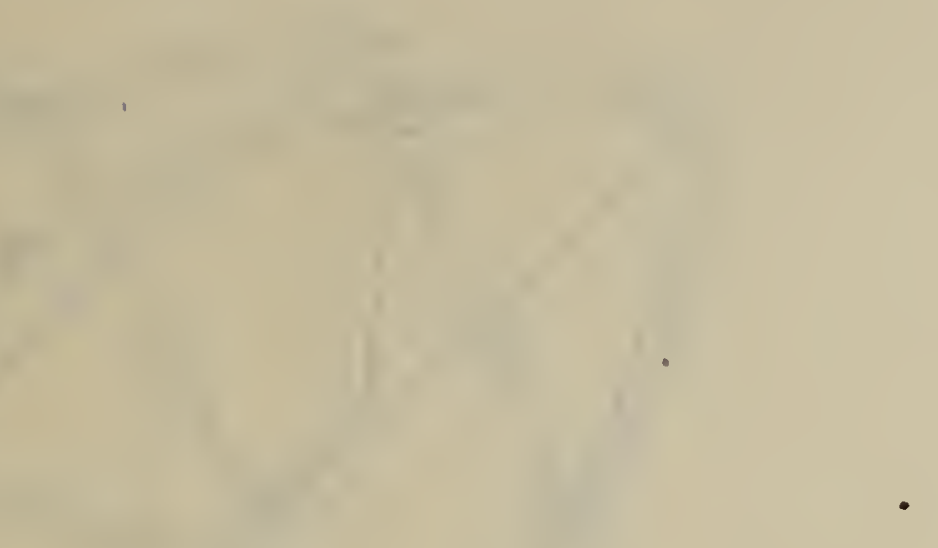

$N=\frac{10}{20}$

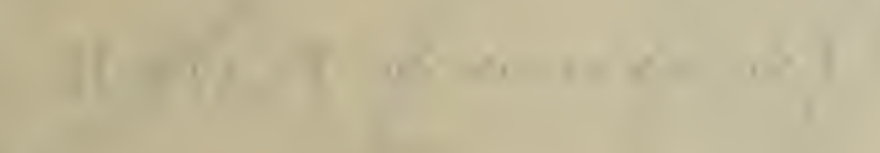

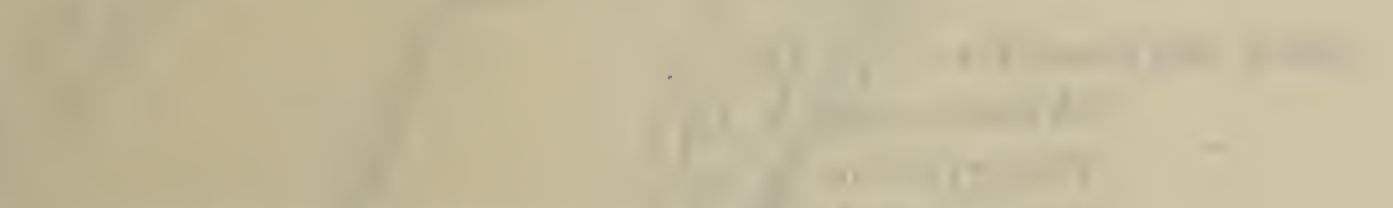

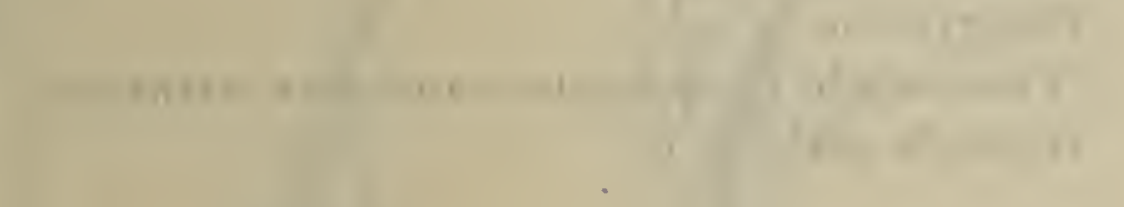

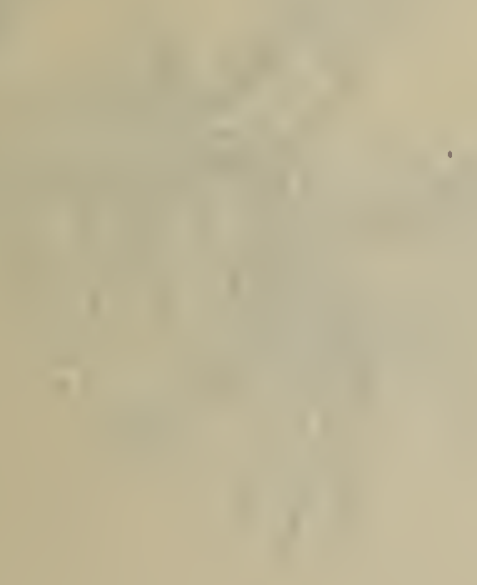




\section{Explanation of Plate II.}

Carex shortiana Dew., p. $34^{\circ}$.

Whole plant $\times \stackrel{5}{5}$.

Perigynium $\times$ il.

(This should show slight transverse wrinkles.)

A single scale $X$ I I. 
PLATE II.

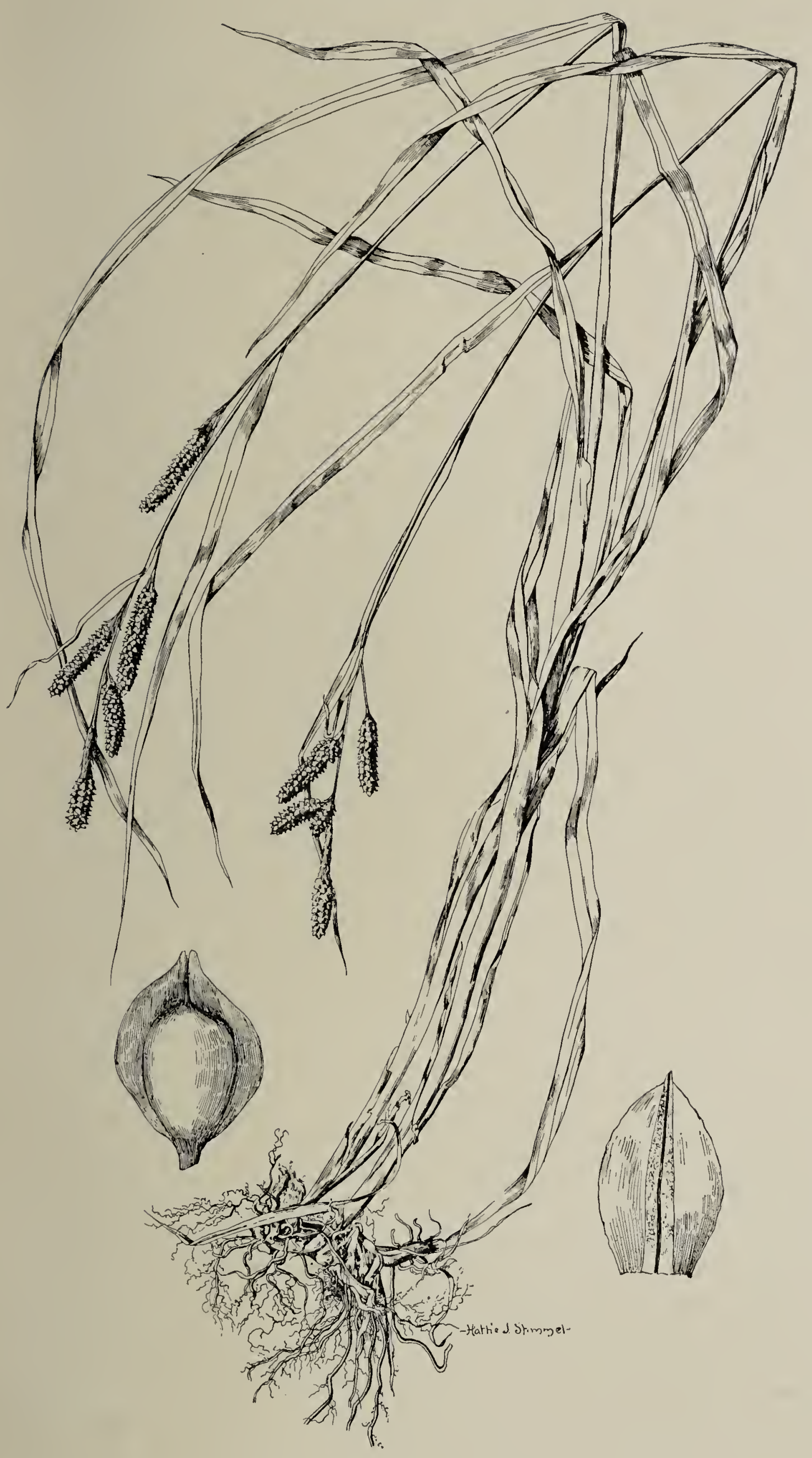


LIBRARY

OF THE

UNIVERSITY OF ILLINOIS 


\section{.}




\section{Explanation of Plate III.}

Carex amphibola Steud., p. 344.

Whole plant $x \frac{1}{3}$.

Perigynium and scale, each $\times 9$. 
PLATE III.

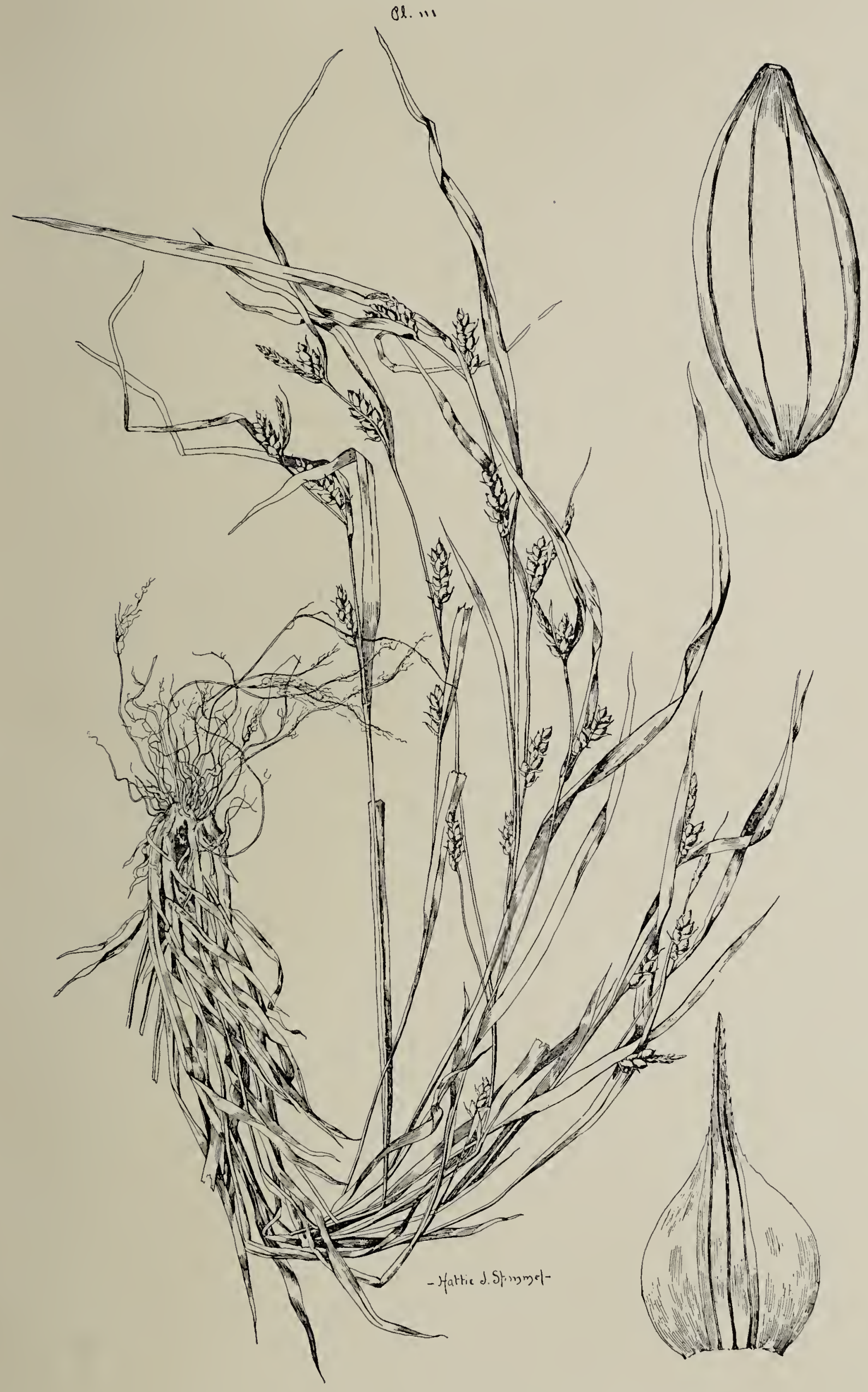


LiBRARY

OF THE

UNIVERSITY OF ILLINOIS 


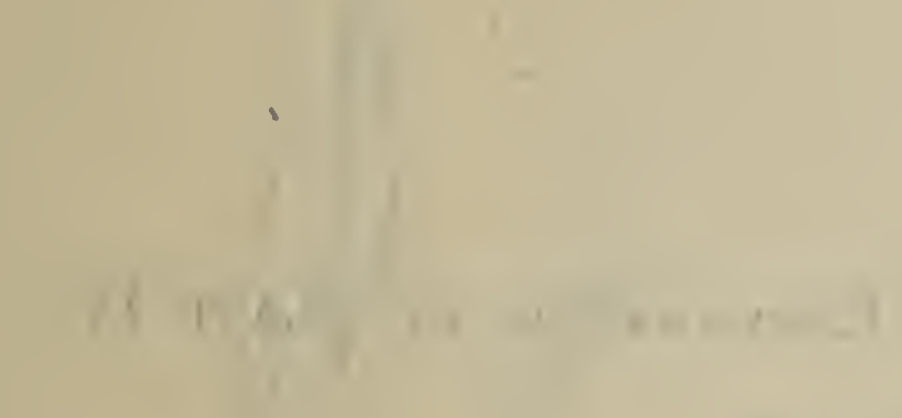

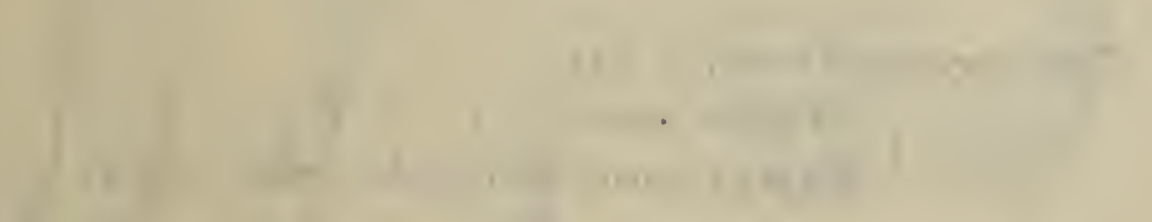


Explanation of Plate IV.

Carex crawei Dew., p. 345 .

Whole plant $\times \frac{1}{2}$.

Perigynium and scale, each $\times 12$. 


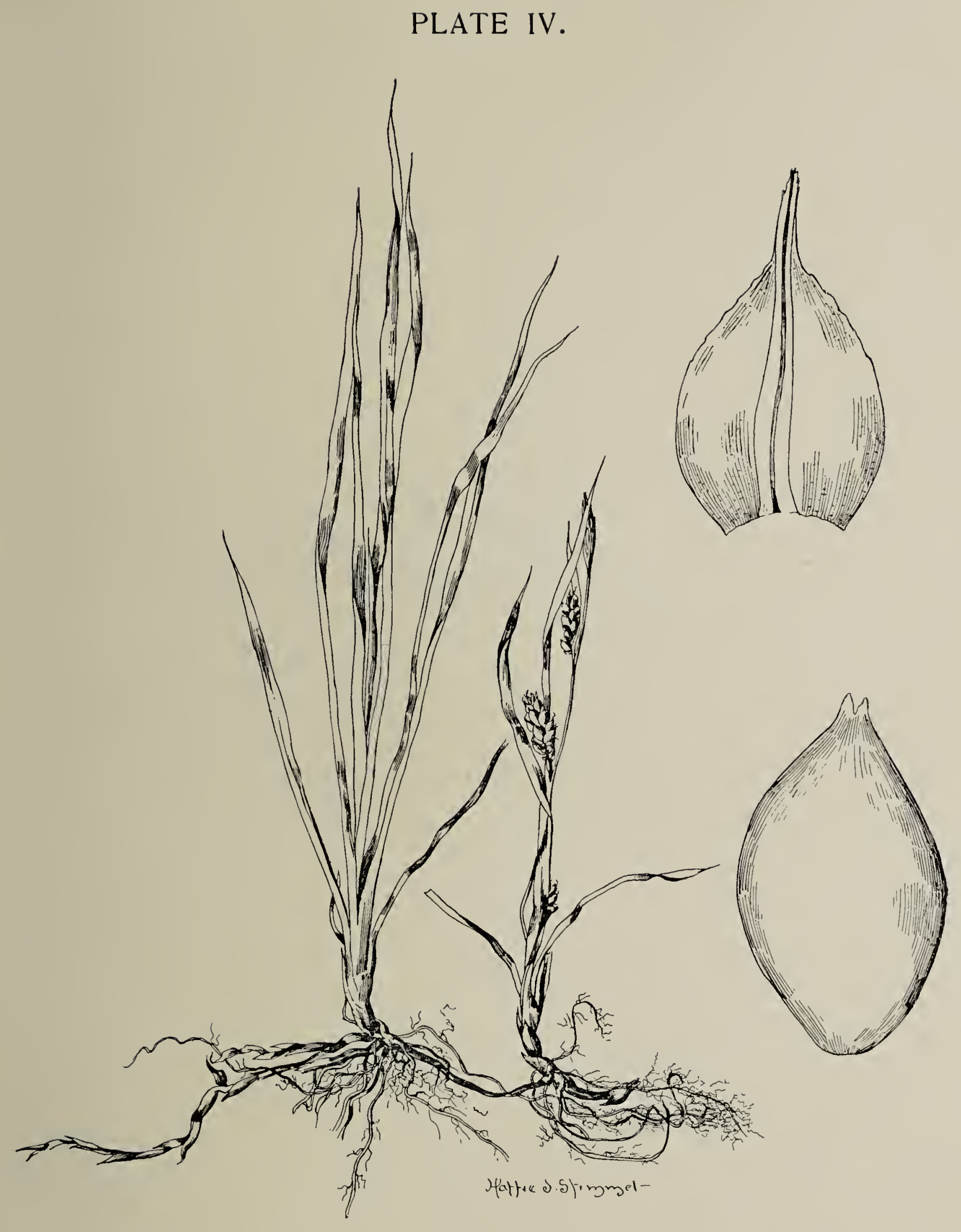




\section{IIBRARY \\ OF THE \\ UNIVERSTY OE ILLWOIS}



Explanation of Plate V.

Carex a gitalis copulatı Bailey, p. 347 .

Whole plant $\times \frac{2}{}$.

Perigı nium and scale, each $\times$ is. 
PLATE V.

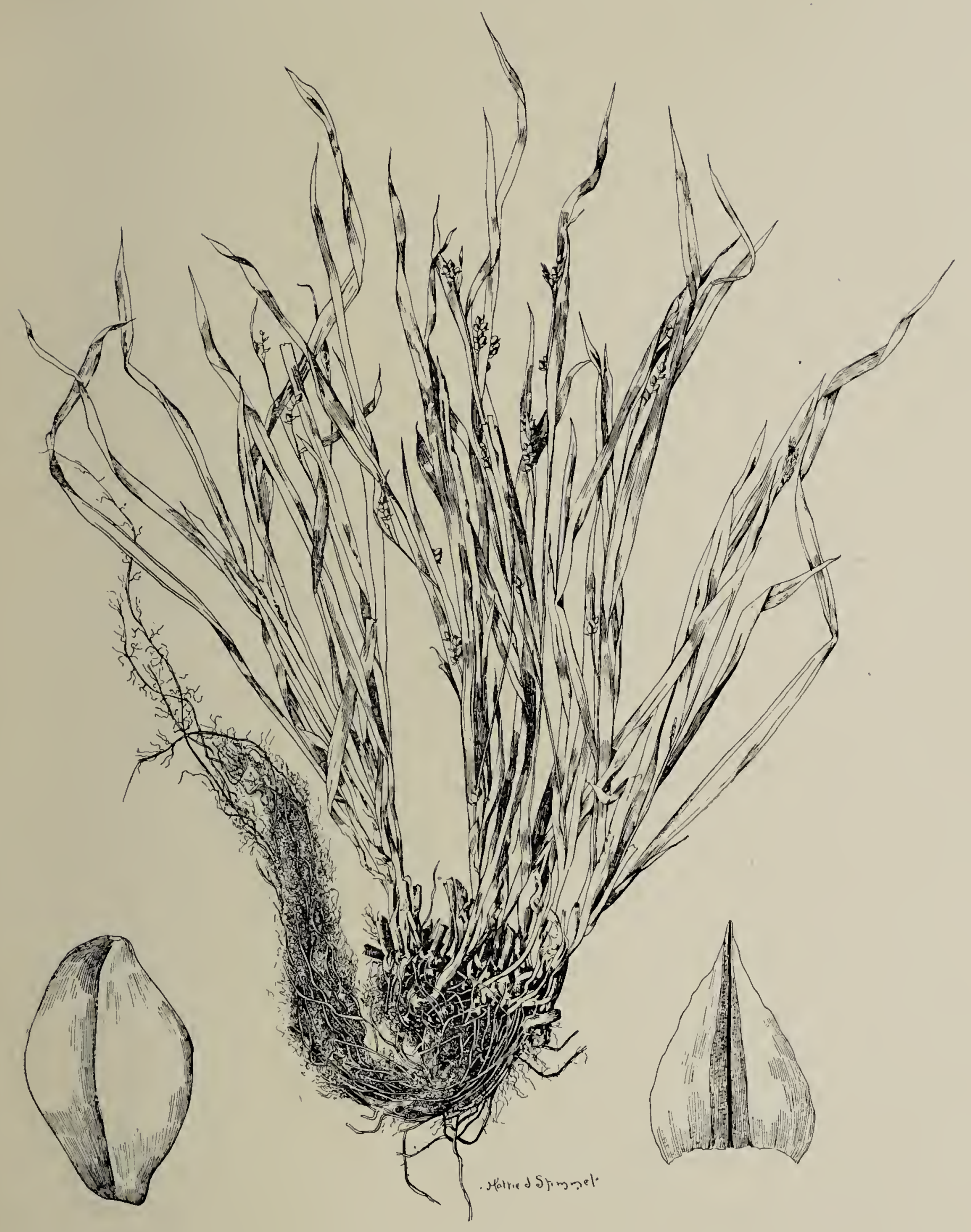




\section{LIBPARY \\ OF THE \\ UNIVERSITY OF ILLIMOIS}




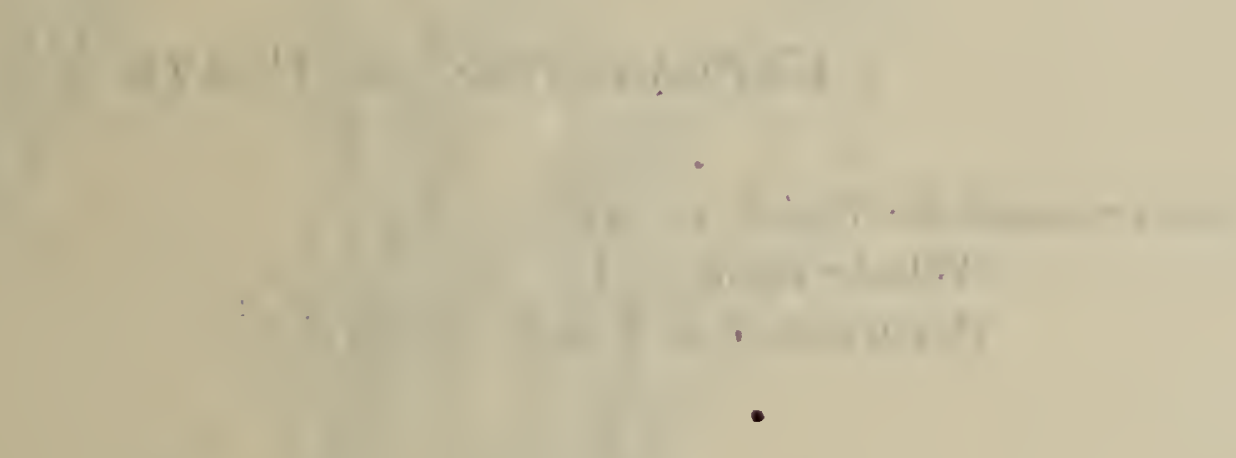


Explanation of Plate VI.

Carex stenophylla Wahl., p. 35 I.

Whole plant $\times \frac{2}{3}$.

Perigynium and scale, each $\times 16$. 
PLATE VI.

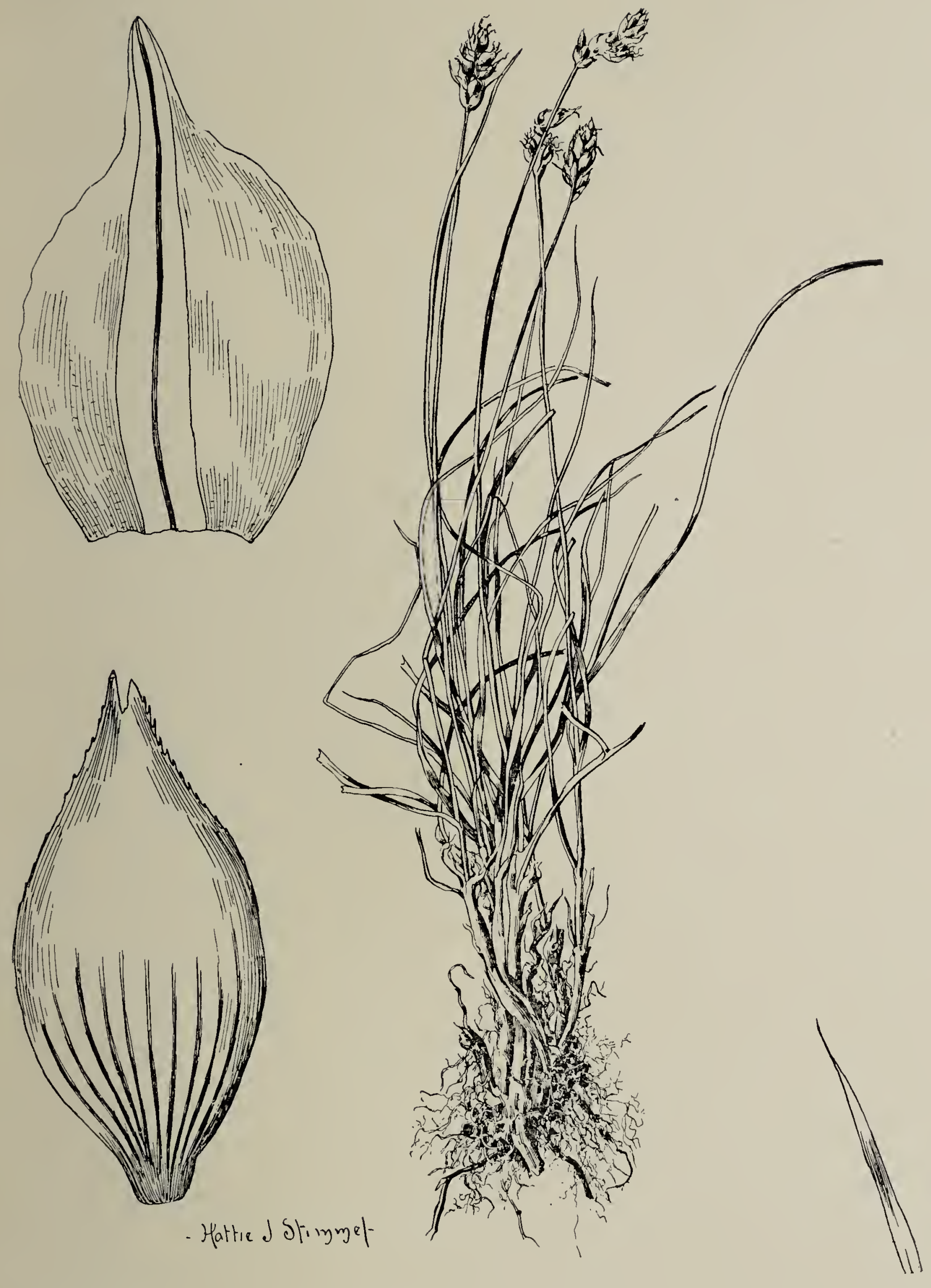




\section{LIBRARY \\ OF THE \\ UNVERSITY OF ILLMUIS}




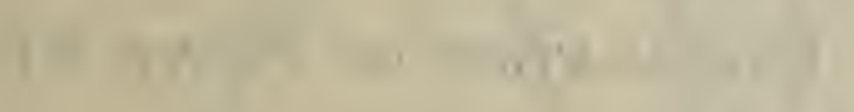

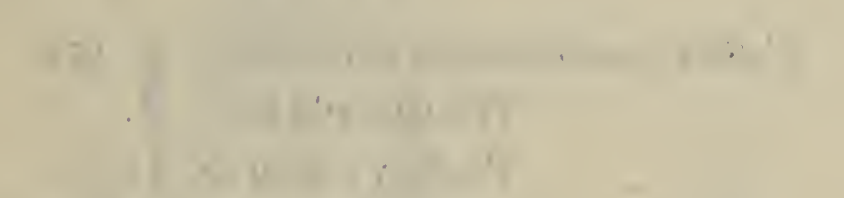

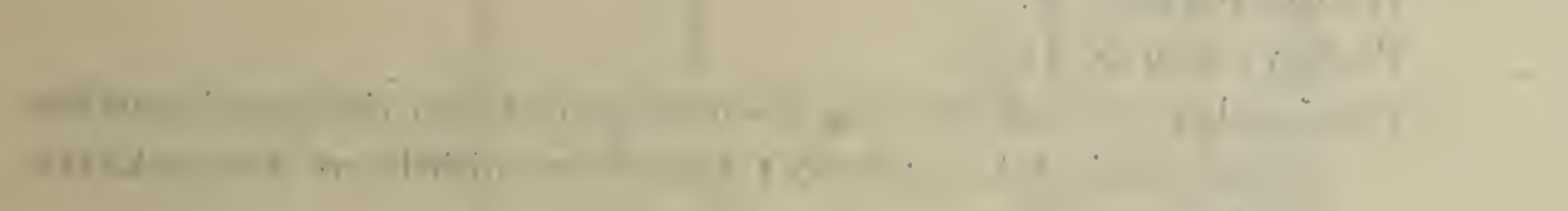




\section{Explanation of Plate VII.}

Carex xanthocarpa Bicknell, p. 354.

Whole plant $\times \frac{2}{5}$.

Perigynium $\times$ II.

Two scales; the upper long-awned scale from the basal portion of the spikelet, the lower from the middle of the spikelet, each $\times$ II. 
PLATE VII.

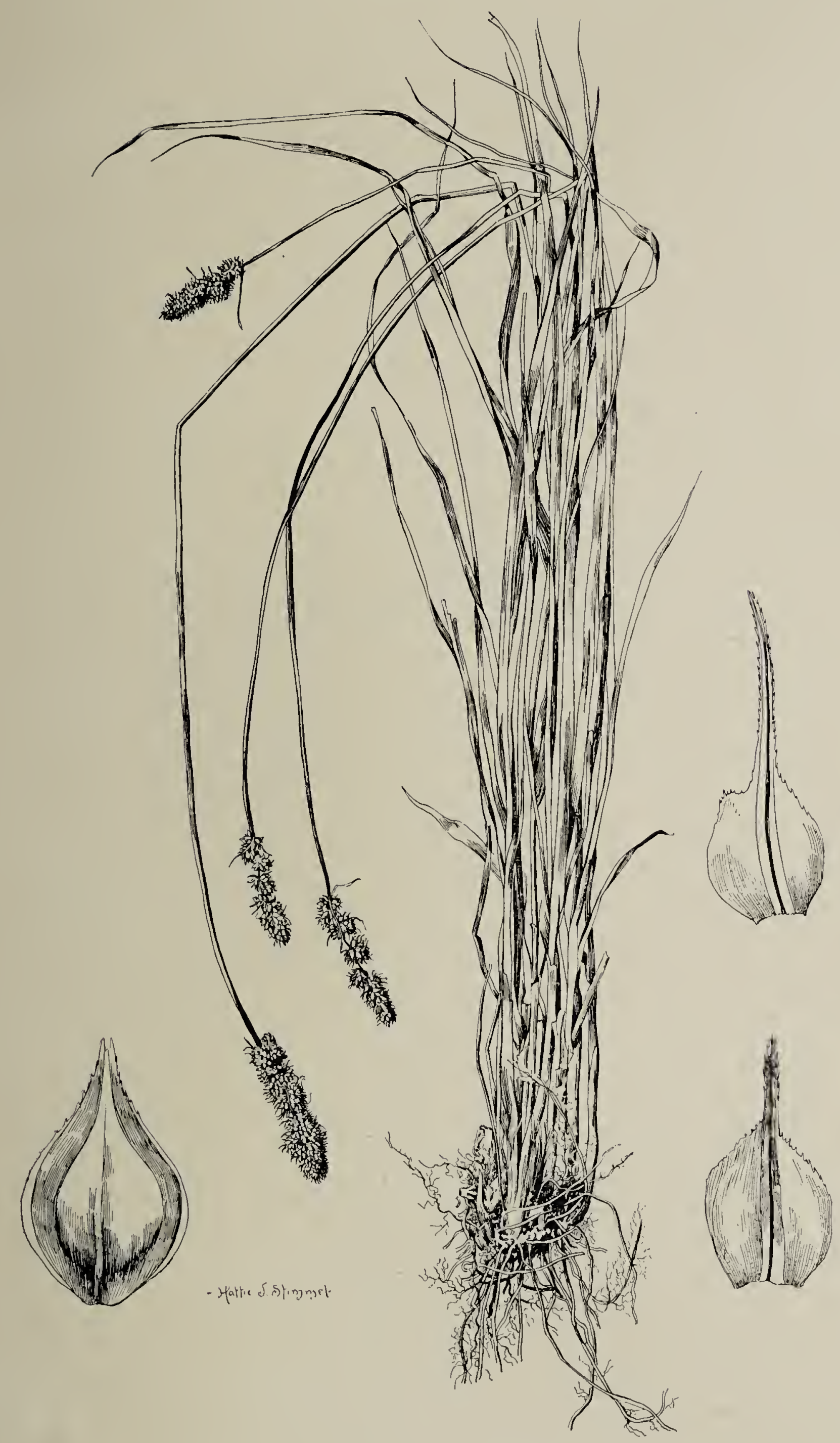


LIBPARY

OF THE

UNVERSITY OF ILLROS 


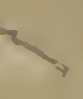




\section{Explanation of Plate Vili.}

Carex tribuloides bebbii (Olney) Bailey, p. 359.

Whole plant $\times \frac{2}{5}$.

Perigynium and scale, each $\times$ I $\mathrm{I}$.

The reference in the text, p. $36_{3}$, should be after No. 66 instead of No. 65 . 
PLATE VIII.

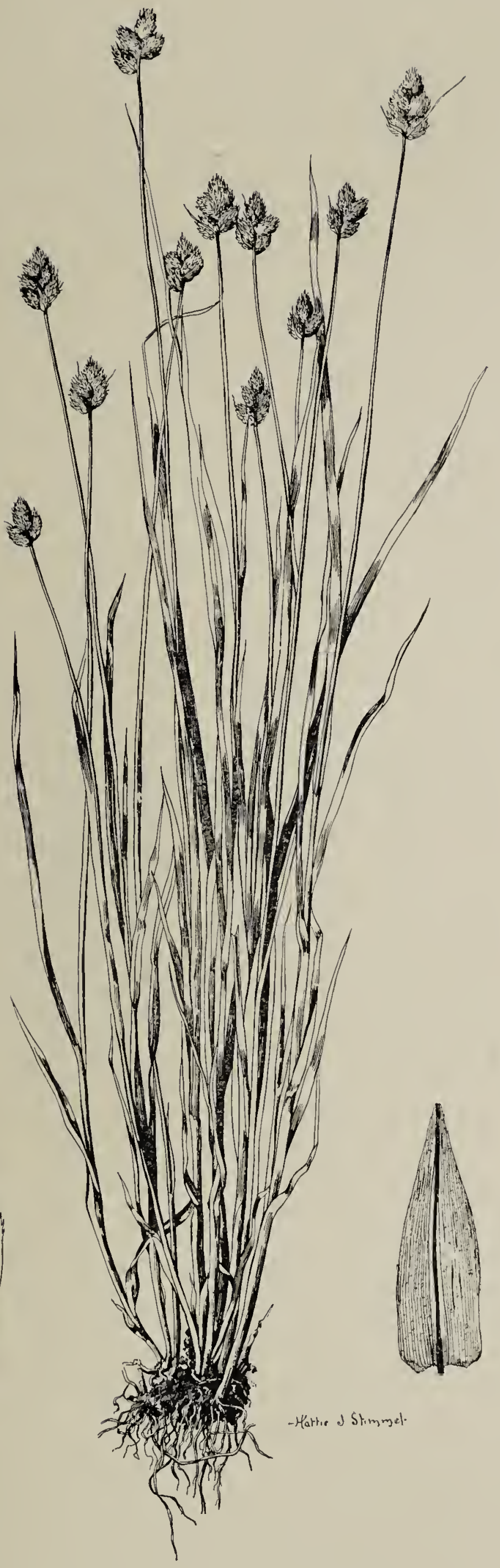




\section{LIBRAPYY \\ OF THE \\ UNIVERSITY OF ILLINOIS}


Explanation of Plate IX.

Carex sychnocephala Carey, p. $3^{6} 3$.

Whole plant $\times \frac{3}{3}$.

Perigynium and scale, each $\times 9$. 
PLATE IX.

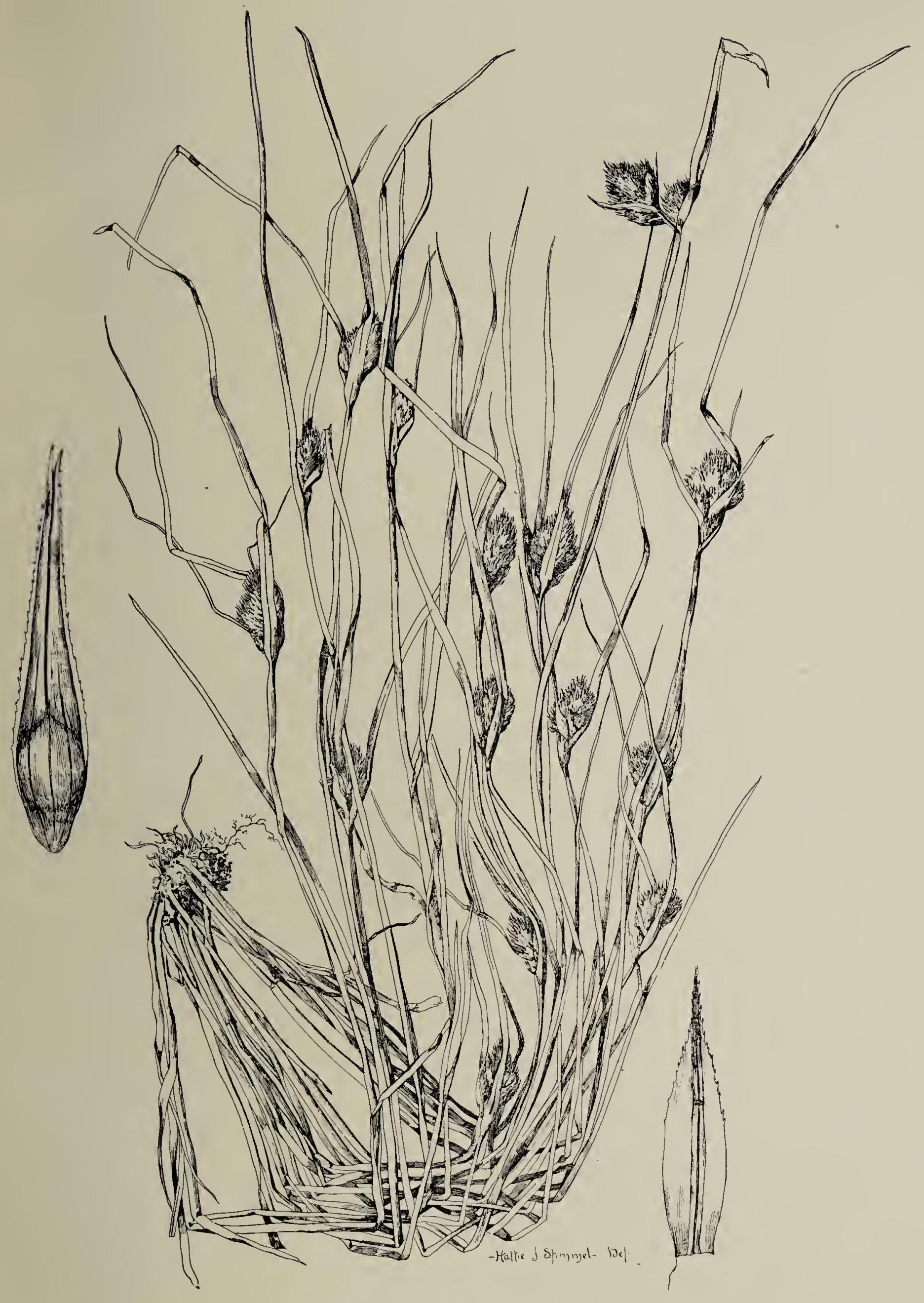




\section{LIBRARY \\ OF THE \\ UNIVERSITY OF ILLINOIS}




\section{Explanation of Piate $\mathrm{X}$.}

Cyperus esculentus L., p. 320

Whole plant $\times \frac{1}{3}$

Immature akene, wifh the three filaments from which the anthers have fallen, $\times 9$.

A single scale $\times 9$. 
PLATE $X$.

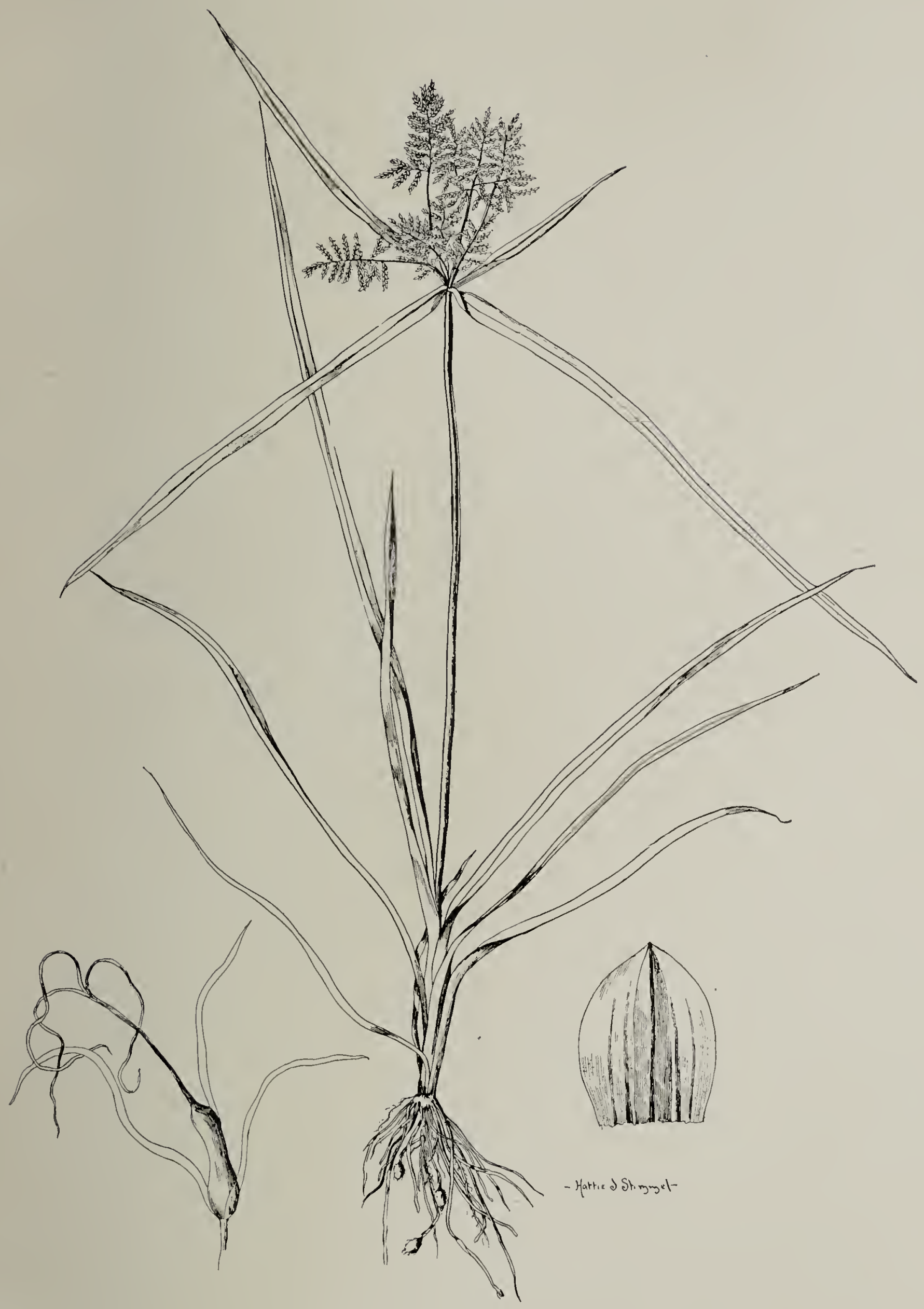




\section{5}

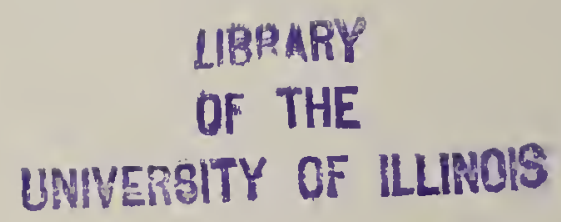

